§シリーズ・ワークショップ“救急医療を考える一明るい未来を拓くために今一”より（2)(3回シリーズ）

\title{
SW3 救急医の役割
}

\section{SW3-1}

\section{救急医の役割}

日本医科大学武蔵小杉病院救命救急センター

\begin{tabular}{|c|c|c|c|}
\hline 黒川 & 畧本 & 恭子 & 望月 \\
\hline 上田＼cjkstart康晴 & 上笹 & 宙 & 牧 \\
\hline
\end{tabular}

昭和40年代の後半に，増え続ける交通事故による重度 外傷への対応，社会問題となった重症傷病者のたらい回 しなどへの対応策のひとつとして, 昭和50年に東京都に 3 つの救急医療センター（日本医科大学付属病院, 東邦 大学大森病院, 武蔵野赤十字病院) が作られ, 重症傷病 者の最後の些的な施設として運用が始まった。昭和 52 年, これをモデルに作られた救急医療体制は, 救急医療 機関を初期, 二次, 三次に分類し, 救急患者も一次から
三次に選別しそれぞれを対応する医療機関に搬送すると いうもので，現在も続いている。

これに則り, 日本医大の救命救急センターは三次救急 患者だけを自己完結的に診療するという運営法をとって きた (図1の上段)。しかし，千駄木の本院と多摩永山病 院の救命救急センターでこの運営法を推し進めている間 に，自己完結型運営の限界を感じ，また二次と三次患者 を分類することの無意味さを痛感するようになった。平 成 15 年 10 月に日本医科大学付属第二病院（平成 18 年 4 月 1 日から日本医科大学武蔵小杉病院と改称）に異動し 救命救急部を創設したのを契機に, 三次救急施設と救急 医のあり方を変えつつある。なお, 当救命救急部は平成 18 年 4 月 1 日付けで救命救急センターに指定された。

\section{自己完結型運営法の限界}

自己完結型とは，救命救急センターの中で全ての傷病 者の初療から退院までの治療の一切を完結させるという やり方である。豊富な人材があれば素晴しい運営法であ るが, 病院全体を考えたとき, 人的・物的（資器材など）

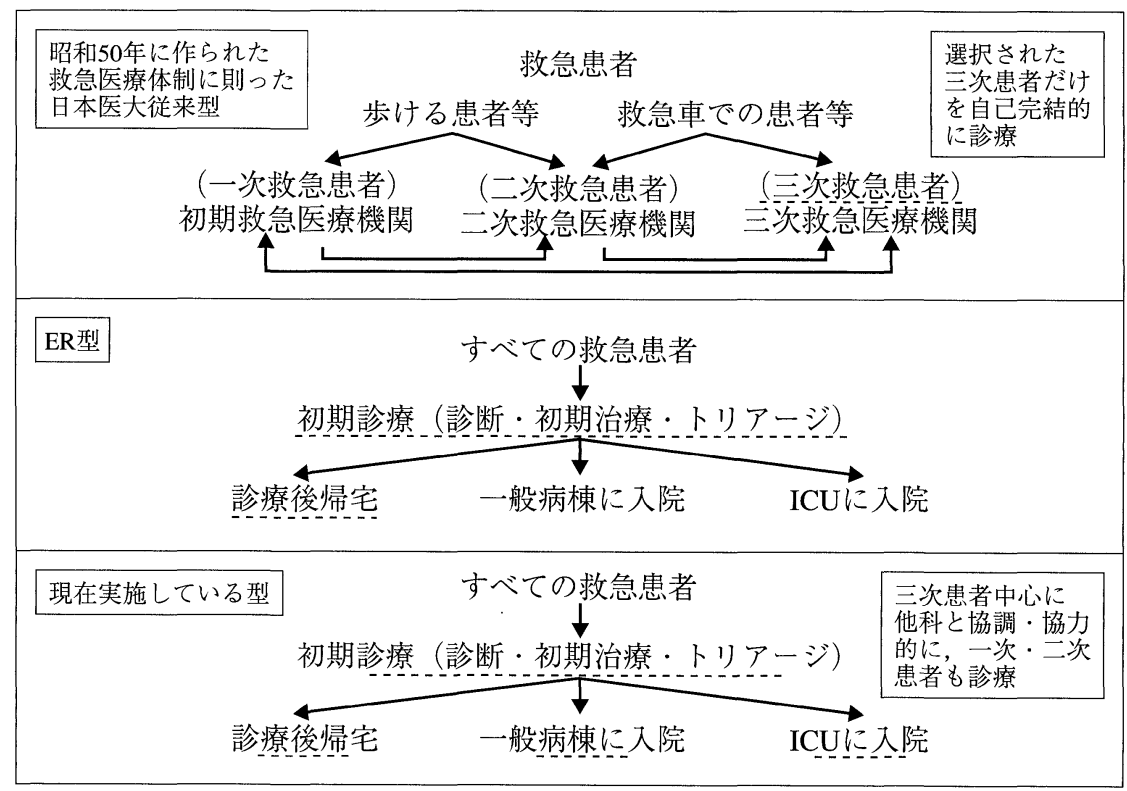

図 1 救命救急センター運営の型 
に効率が悪い。さらに，全ての分野に対応できる医師を 揃え，いつまでも維持することは至難の業である。しか も, 自己完結型運営をすればするほど救命救急センター と他科の連携は覀くなり, 救急医療を通して病院全体の 活性化をすることに逆行することになる。

\section{二次と三次を分けることの無意味さ}

当院に異動してから救命救急部として活動を始めた。 メンバーはいずれも救命救急センターで仕事をしてきた 者ばかりなので，三次医療をするつもりであったが，周 囲の扱いは二次施設であった。名称や扱いはどうであれ， これまでやってきたように，どんな患者でも引き受ける ことを旨としてスタートした。そして，ことに他の救命 救急センターで断られた症例やあちこちで断られまくっ た患者は, 軽かろうと重かろうと必ず受けることに徹し た。こうしていると，二次施設，三次施設とは何だろう と一層思わざるを得なかった。救急医療施設においても 救急患者においても重症度は相対的なもので, 二次と三 次を絶対的に区別できないし，重症度や病態は刻々と変 化するので, 救急患者を二次と三次に区別することは意 味がない, すなわち, 一次救急患者はともかくとして, 二 次と三次救急患者を分けることは無意味たということを 強く感じた。現在の救急医療体制は, 救急隊や病院中心 のものであって，患者中心のものでないと実感するよう になった。

\section{救命救急センターと救急医の役割}

当救命救急センターの運営方針：1）三次救急患者に対 する集中治療を主とするが, 総合診療部的に一次, 二次 救急患者にも対応する。すなわち, 三次救急にこだわら ず，各科対応の一次と二次救急にも補完的に対応する。2) 自己完結型ではなく, 協調·協力型をとる。個々の症例に 対しては, 初療をしつつ診断をつけ, 専門分野の医師に 任せるべき場合には協力を依頼し，一緒に治療に当たる。

図の下段が当救命救急センターの運営法を示したもの である。図の中で, 救命救急センタ一医師のかかわりの 程度を, カバーする分野に付けた下線（破線）の長さで 示した。上段の従来, 日本医科大学が行ってきた自己完 結型では, ほぼ三次救急だけを対象に集中治療を行って きた。中段のER型は, 全ての救急患者の初療を行い, 一 次の患者は診療して外来フォローとするが, 入院が必要 なものは, トリアージまでを担当するのみで，あとは各 科医師に任せるというものである。下段の現在われわれ が実施している運営法は, 集中治療を要する患者のほと んどと, 二次と一次救急患者の診療の一部を担うという
表 1 救急医の役割

地域医療に対して：受入れ先がなく救急隊が困っていた り, 何らかの理由で他院が診れない症例は, 一次, 二 次, 三次に係わらず診る

院内的には：自己完結型から協調・協力型への転換によ り, 救急患者受入れの円滑化を図り, 病院の活性化に 寄与する

1. 三次救急患者の初療から集中治療まで行うが，院内 他科の専門的治療が必要な場合は, 協力を依頼する

2. 院内各科が対応する一次・二次救急を, 救命救急七 ンターが補完する

3. 院内他科が断りがちな症例は, 一次·二次の別なく, 総合診療部として診て, 再び尃門科にfeedbackする

4. 以上, 双方向型の協調·協力を推進する

ものである。

救急医の役割をまとめて表 1 に示す。

\section{この方針で得られた効果と今後の課題}

協調・協力型により, 当科から他科へのコンサルテー ションが増えたのはもちろんであるが, 逆に他科から当 科へのコンサルテーションも増えた。このような双方向 型の協調・協力体制が生まれたことで, 病院全体の活性 化に大きく貢献した。

課題は, 現状では救命救急センターのスタッフ数が少 ないため, スタッフ個人の負担が大きく, 一次と二次救 急医療を補完の形でしかできないことである。今後，ス タッフが増えれば一次，二次救急医療を補完の形でなく， 全て診ることができるであろう。この型はER型(図の中 段)に近いが，ER型は院内でトリアージをして二次，三 次の患者をそれぞれの科に渡すまでを担当するのに対し， 当科が行っているのは協調・協力型の集中治療と総合診 療部的救急では，単に初療とトリアージをするのではな く, 三次を中心とした集中治療と, 二次も一次医療も行 い，全てにおいて協調・協力していくというものであり， 異なるものである。

\section{結語}

救急医の役割は以下の通りである。

1. 依頼があった傷病者は当然のことながら，救急隊が 困っていたり，他院が断った症例は一次〜三次の別 なく，万難を排して引き受ける

2. 自己完結型にこだわらず，院内の力を結集するよう な協調・協力型をとる

3.これらを通し, 患者中心, 地域中心の医療が実践さ れ，かつ病院の活性化に寄与する 


\section{SW3-2}

\section{高度救命救急センターにおける 救急医の役割}

1 札幌医科大学附属病院救急集中治療部・高度救命救急センター, ${ }^{2}$ 日鋼記念病院救命救急センター, ${ }^{3}$ 市立函館病院救命救急センター

奈良 理 ${ }^{1}$ 森 和久 ${ }^{1}$ 丹野 克俊 $^{2}$

武山 佳洋 $^{3}$ 岡本 博之 ${ }^{1}$ 井上 弘行 ${ }^{1}$

浅井 康文 ${ }^{1}$

\section{はじめに}

当施設は外傷診療を目的として1965年に設置された災 害外傷部が，周術期管理を目的として別に設置されてい た集中治療部門と統合され1985年に救急集中治療部とし て開設された。組織的には附属病院中央部門であるが, 独立した診療科として診療・研究・教育を実践し，現在 救急部門は高度救命救急センターとしての役割を担って いる。高度救命救急センターの診療体制は基本的に専従 救急医と専従各科専門医が主治医として診療にあたり， 特殊疾患の場合等必要に応じて附属病院各診療科と連携 をとりつつ診療にあたっている。今回われわれは，当施 設における救急医の役割を述べ, 更に今後の展望と問題 点についても言及する。

\section{当施設の概要}

高度救命救急センターのスタッフ(医師)は，センター 長（救急集中治療部部長，教授）以下，専従救急医（救 急集中治療以外のサブスペシャリティーを持たない医師） 5 名（日本救急医学会指導医 3 名, 日本救急医学会専門 医 1 名) と心臟血管外科医，一般外科医，脳神経外科医， 整形外科医, 麻酔科医, 循環器内科医各 1 名（全て各科 専門医でうち日本救急医学会専門医 4 名) の 12 名で構成 されている。この他に年度により変動はあるが約 8 名の 医員（救急専門 4 名，他診療科 4 名）が診療に携わって いる。当施設ではこのように外科系を中心としたスタッ フ構成となっている。2004年度の年間搬入症例数は 1,142 例（救急隊直接 $63.2 \%$, 転院 $23.8 \%$, 院内外来 $13.0 \%$ ) で
主な疾患の内訳は，外傷 $40 \%$ （熱傷 3\%を含む），心肺停 止 $21 \%$ (内因性 $11 \%$, 外因性 $10 \%$ ), 循環器系疾患 $10 \%$, 中毒 $7 \%$, 脳血管疾患 $6 \%$, 消化器系疾患 $5 \%$, 呼吸器 系疾患 $4 \%$ ，その他 $7 \%$ であり，また平均のセンター内 入院日数は $7.3 \pm 13.0$ 日（1～144 日）であった。高度 救命救急センター設置 (2001年 10 月) 以降の搬入数とそ の内訳に大きな変動はない。このような搬入症例に対し て専従救急医は, 専従専門医あるいは附属病院他科専門 医と協力し, 緊急搬送を含めた病院前救護, 初期診断 · 治療を主体的に実施し，専門医チームへの連携を円滑に 行う役割を担い, またセンター内で治療が完結可能な症 例に関しては, 主治医としてクリティカルケアを担当し ている。心肺蘇生, 重症外傷, 急性冠症候群, 大動脈疾 患, 広範囲熱傷, 急性薬物中毒などの疾患群に関しては, 専従救急医と専従専門医を中心とした診療体制が確立し ている。このような体制構築には，約10年の歳月を費や したが，高度医療に特化した部門にもかかわらず，医学 部卒業後, 既存の専門科を長期間研修することなく, 高 度救命救急医療とクリティカルケアのみを習得するシス・ テムを踏襲し続けたことが，専従救急医に “identity”を 持たせ, その結果として附属病院内での一定の評価と地 位を確立しつつあると考えている。この間に養成された 約 40 名の救急医の 3 分の 1 が, 当施設を含めた救命救 急センターで救急専門として活動している。

\section{問題点と今後の展望}

当施設における専従救急医と専従専門医に共通した問 題点は, 人員不足による負担増が第一に挙げられ，この 点に関しては他の施設も同様と推察される。救急専従医 に関しては，診療にかかわる部分のみを考慮した場合に は，必ずしも過剩労働にはなってはいないが，メディカ ルコントロールを含めた救急隊員教育や最近盛んに行わ れている off the job trainingへの参加等を考慮すると負担 増と言わざるを得ない。一方専従専門医に関しては，実 労働時間は決して多くはないが，基本的に24時間365日 オンコールという精神的な負担が大きな問題となってい る。また専従専門医にとって出向期間が長期となった場 合, 専従専門医が “救急医化” し, 施設的には歓迎すべ き状況になるが専門医としてのモチベーション維持に苦 慮し, 場合によっては出向元診療科から孤立することも 問題となる。上記の問題の解決には, ターンオーバー制 で勤務できるように増員することが必要であるが，実現 
は容易ではないのが現状である。

当施設に特徵的な専従救急医の問題点として, 当施設が 大都市型の高度救命救急センターであり, 本邦型の病院前 救護体制が進んだ地域に所在しているため，そのような条 件においてのみ十分な力を発揮できる資質を持った専従救 急医の養成を行ってきたことが挙げられる。北海道には当 施設が所在する札幌市以外の 5 地域に救命救急センターが 設置されており(その他に札幌市を含む 2 箇所に新型救命 救急センターが認可された), 実際に札幌市以外の救命救 急センターで求められている専従救急医の資質は，いわゆ る北米ER型の診療にも対応できることである。したがっ て，今後は大都市のみならず全ての救命救急センターに必 要な人材を養成するような新しい教育システムを当施設で
も模索する必要がある。また，本邦においても救急医がそ の力を発揮する職種として, 諸外国では存在しているメ ディカルディレクターを地域や消防機関に配置するような 働きかけも今後必要であると考えている。

\section{まとめ}

高度救命救急センターにおける救急医の役割に関して, 当施設の現状と問題点, 今後の展望について述べた。当 施設では専従救急医のidentity と専従専門医の救急医化に よって円滑な高度救命救急医療とクリティカルケアが実 現し一定の評価を得ている。今後は他施設で求められて いる救急医の役割を検討し，本邦における救急医のidentity を確立していきたいと考えている。

\section{SW3-3}

\section{地方都市での救命救急センターにおける 救急医の役割について}

\author{
亀田総合病院救命救急センター
}

弥永 真之

地方都市にある救命救急センターである当院における 救命救急科の役割と問題を，外来診療・入院診療・教育 の点から報告する。なお，当院救命救急科は有床型ER方 式を採用している。

当救命救急センターは千葉県房総半島南端の鴨川市に 位置し，約11年前に急性期総合病院に併設され以来一次 から三次全ての救急患者の受入・診療を行っている。昨 年度一年間の受診患者数は, 外来受診患者数 31,890 名 $(一$ 日平均 87 名) - 救急車搬送患者数 4,412 名（一日平均 12 名）であった。救命救急センターは処置室 4 床・観察室 8 床・外来 6 部屋で構成されている。また集中治療室 6 床・一般病床 18 床の救命救急病棟があり, 当院は包括医 療（DPC）を採用していることから主に救急加算対象患 者が診療科にかかわらず入院している。

当救命救急科は上級医師 3 名・シニアレジデント 6 名. ローテーション中の初期研修医 3 名で構成されている。 主な業務は，救急車及びドクターヘリ搬送患者の診療， 平日日直帯の外来患者の診療, 重症患者や外傷患者の入

\section{院診療である。}

当院外来診療に打ける救急医の役割として，上級医師 あるいはシニアレジデント $1 \sim 2$ 名と初期研修医 1 名か らなる2〜3名のチームにより 24 時間交代で救急車・へ リ搬送された患者の診療にあたる。当院の地理条件から 千葉県南部の診療所や病院からの紹介搬送患者も多い。

救命救急科の外来診療について一定水準以上の質を維 持するには，チームを組み診療技術や処置技術を共有す ることが重要である。質の維持のためには標準化された 診療を行うことが前提であり，ACLSやJATECに沿った 診療を心がけている。また，毎朝前日の救急搬送患者の 症例報告を日課として行い，実際の診療を振り返ること で診療の質の向上に努めている。

一方で，夜間や祝祭日の外来受診患者は一部を除き救 急科のかかわりはない。当院では 3 年前までは初期研修 医が救急外来当直をする制度がなく，各専門医に救急外 来が任されていた。3 年前よりようやく初期研修医が救急 外来当直に組み込まれ，本年度より院内から 10 名程度の 救急外来指導医（救命救急科より 4 名が参加）が時間带 を限って初期研修医の指導を行うこととなった。しかし 未だ外来診療の多くは当直をする各専門医にゆだねられ ており，その質にはばらつきがある。なぜなら救急診療 のトレーニングを受けていない専門医が少なからず存在 するからである。とりわけ重症患者や外傷患者への迅速 な対応，あるいは適切な専門医のコンサルテーションに は各専門医間に大きな差がある。

また専門医外来にフォローアップを依頼した場合に， 救急外来での対応の妥当性について専門診療科から フィードバックを受ける機会が少ない。 
シリーズ・ワークショップ

今後の課題として, 救急科主導で初期研修医を含めて 救急診療ができる医師が養成され救急診療により多くの 医師がかかわっていくことが必要である。専門以外は診 療能力が高くない医師が救急診療にかかわることはその 医師にとっても患者にとっても不幸なだけである。

また, 各専門診療科とのより円滑な診療を行うために, 外来診療の標準化を共同して行うべきである。救急外来 にて行う評価や処置が専門医にとって妥当であった，そ うした検討とフィードバックを行う機会を設ける必要が ある。これは救急外来の診療の質向上のみならず，専門 医療の充実にもつながるものと考える。

入院診療に打ける役割として当院救急科は外傷・中 毒・熱傷など外因性疾患を中心に重症内因性疾患を加え て平均 20〜30人の入院患者の診療を行う。とくに外因 性疾患に関しては救急科がその専門科として診療にあ たっており，院内のコンセンサスも得られている。重症 患者の診療は初療・入院後の診療とも救急医を中心に専 門医とのチーム医療にて診療にあたる。当院には集中治 療専門の医師が非常に少なく, 結果的に救急医が入院後 の診療チームのかじ取り役を行うことが多い。これまで に呼吸・循環を始めとする全身管理をする機会が多かっ た経緯から，他の専門診療科に比べて集中治療の経験が 多く慣れており当院における集中治療の多くを担ってい る。

しかし救急科が入院診療すべき疾患が院内に明確にさ れているわけではない。このため救急医・専門医それぞ れ各医師の間で自分が属する科がどこまで主導して診療 すべきかという点で認識の相違が存在する。

また専門科に依頼しづらい医療的問題を抱えた患者, 例えば衰弱にともなう全身状態の悪化した患者の診療, 及び慢性期の医療的問題のみ抱えた患者, あるいは重症 患者が軽症化しても, それらの診療を救急科が行わざる を得ないことがある。
今後改善すべき点として, 各専門科と入院診療の対象 について具体的な取り決めを行うべきである。

最後に教育に関して当院の初期研修では救命救急科の ローテーションが義務付けられており，上級医やシニア レジデント指導の下幅広い臨床経験をつむことができる。 とくに医師の技能として必須である心肺蘇生や小外科手 技, 致死的疾患の対応を初期研修医に教育するのに救急 医が果たす役割は大きい。

当院のシニアレジデントは救命救急科業務と別に院内 の専門科をローテーションする機会が計一年間与えられ ており, 各人が希望する診療科で研修を積むことができ る。専門科の診療技術の習得のみならず, 専門科と救急 科とのより良好なコミュニケーションを図るために役 立っている。

また救急科医師により院内や近隣病院医師対象の ACLS 講習会を定期的に開催し, 地域救急診療の向上に 努めている。

さらには救急救命士の院内実習を積極的に受け入れ, 救急救命士のスキル向上に貢献している。年に 3 回周辺 地域の救急救命士と救急科医師・看護師とで集まり搬送 症例の検討会やJPTEC/JATECのデモンストレーションを 行い, 地域救急医療の発展を支えている。

初期研修医・後期研修医両方の研修に共通しているの は, 研修の到達目標が明確でないところである。具体的 な将来の自分の姿を描きづらい環境であると思われる。 また, 外来担当が入院後の担当医となる体制であったた め, 入院診療経験の共有ができていなかった。この7月 より入院診療に関してもチーム制を導入し, 経験の共有 化を図っている。

地域型救命救急センターにおける救急医は, 外来診 療・入院診療・教育の面から特長的な役割を果たしてい る。有床型 ER 方式はいずれの面においても改善点が多 く, 発展途上にある。 
SW3-4

\section{大規模急性期病院の \\ 併設型救命救急センターに括ける 救急医の役割}

\begin{tabular}{lllllr}
\multicolumn{5}{c}{ 飯塚病院救急部 } \\
\\
中塚 & 昭男 & 鮎川 & 勝彦 & 出雲 & 明彦 \\
稲留 & 直樹 & 中村 & 朋子 & 山畑 & 佳篤 \\
徳永 & 正則 & 八田 & 弓子 & 三好 & 修 \\
藤富紀代美 & & & &
\end{tabular}

はじめに

当センターは, 大規模急性期病院である飯塚病院に併 設された救命救急センターで，一次から三次までの救急 患者を対象としている(表1)。診療には病院全職員で取 り組んでおり，1,000床以上の病床と 1,000 人を越える全 職員が支えるセンターで, 平成16年のセンター受診患者 数は 43,256 名, 救急車搬送件数は 7,202 件（図1）と全国 で最も大型の救命救急センターのひとつとして機能して いる。救急医は24時間 365 日, 救急車で搬送される一日 約 20 人の患者の初期診療・初期治療を行い, 院内の各科 専門医へと引き継いでいる。当院のような大規模急性期 病院の併設型救命救急センターでは各科・各部門との連
携を図ることが最も重要であり，そのためにわれわれ救 急医が取り組んでいることについて紹介する。

\section{救急医の役割}

当院は前述のごとく 1,000 床以上を有する大規模病院 であることから，昨今の医療の細分化·専門化に伴い，35 の診療科・部門が存在し，各専門分野では質の高い医療 を提供している。大規模急性期病院の併設型救命救急七 ンターにおける救急医の最も重要な役割は, 救急搬送患 者に対し適切な初期診療・初期治療を施し, 各科専門医 との連携を密にして救急搬送患者に対し最善の医療を提 供することといえる。各科専門医との連携を図るための われわれ救急医の役割として, (1)subspecialtyの習得と(2) チーム医療の実践に取り組んでいる。

\section{Subspecialty の習得}

救急医にはあらゆる疾患・病態に対応する幅広い知識 が必要とされるが，当院ではこういったgeneralistとして の知識にとどまらず，何らかのsubspecialtyを習得するこ とを目標としている。当院における救急医のsubspecialty の習得には 2 つのパターンがある。ひとつは，専修医と して $2 \sim 3$ 年間救急搬送患者の診療に専従し, その後, subspecialty習得のため各科に出向（ローテート）するパ ターンである。当院の年間救急搬送件数は 7,000 件を越え ており，一人あたり 1 年間で $500 \sim 800$ 件の救急搬送患 者の初期診療・初期治療の経験が可能で， $2 \sim 3$ 年間の 専従で各種疾患・病態に対する幅広い知識を習得するこ とできる。この後，本人が希望する科を半年から 1 年間

表 1 病院概況

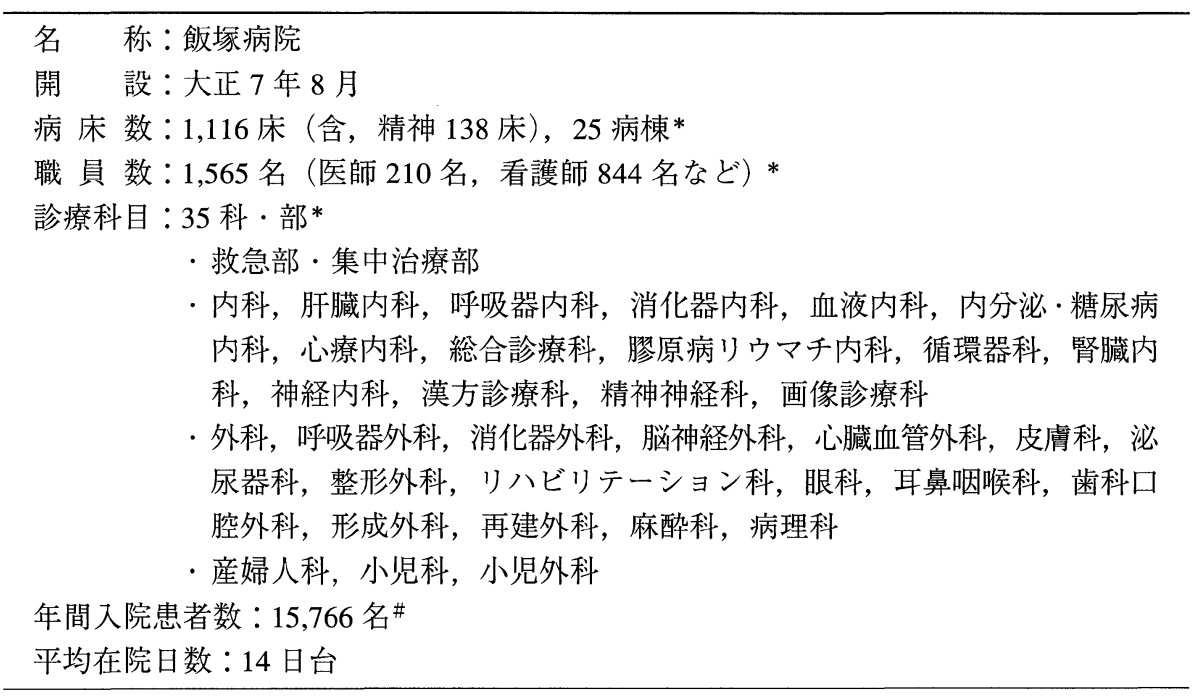

$* 2005$ 年 7 月 1 日現在, $\#$ 数值は 2004 年 $($ 平成 16 年) 


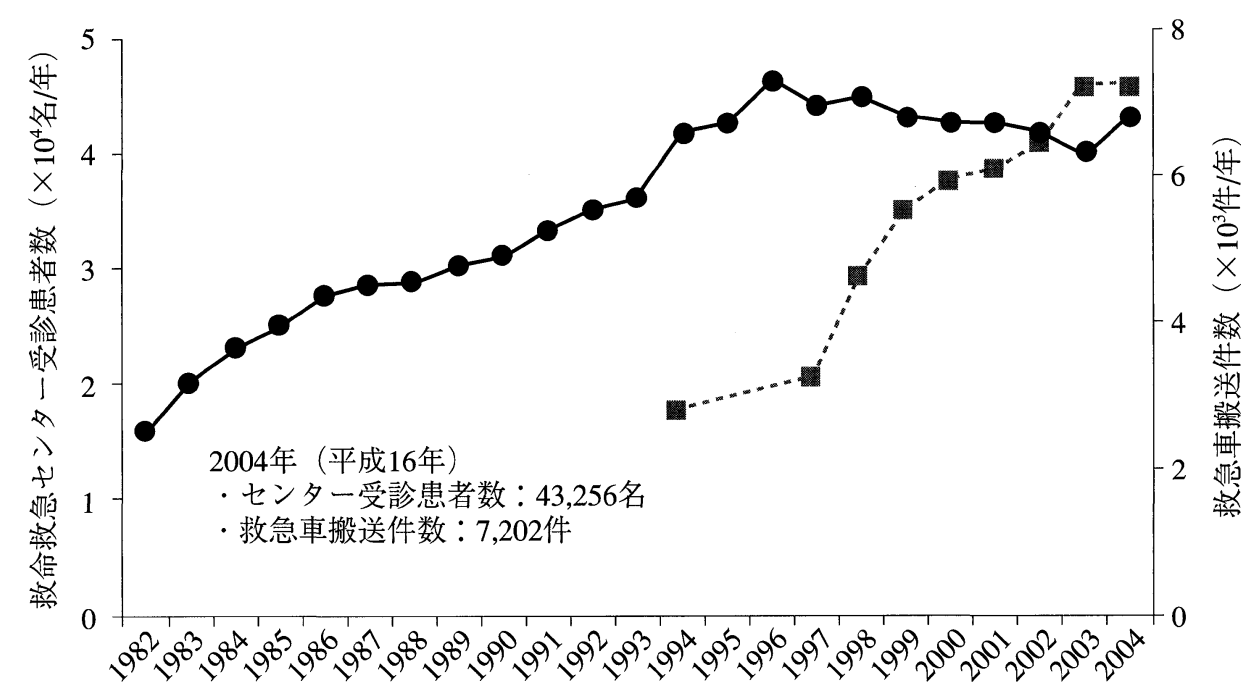

図 1 センター受診患者数

と救急車搬送件数（琟）の移

ローテートして subspecialty の習得に努める。

もうひとつは, 各科専門医としていわゆる specialtyを 習得した後，救急医として専従するパターンである。こ ちらも, 救急医として一定期間専従した後, 更なる subspecialty 習得のため他科をローテートすることもある。

当院のsubspecialty習得の特徴は, 一定期間のローテー トに終わらず，ローテート終了後も各科の診療に携わり， とくに救急疾患を中心に診療のサポートを継続していく ことにある。救急患者の緊急手術や緊急カテーテル検査 などの補助のみならず，時には主治医として入院診療を 担当することもある。最終的に可能であれば, 各科の専 門医を習得することを目標としている点で通常のロー テートと異なっているといえる。救急部スタッフの subspecialtyを表2に示すが，ほぼ全員が何らかのsubspecialty を習得しているか，もしくはローテート中であり，うち 6 名が各科の認定医もしくは専門医 (specialty) を習得し ている。

救急医がsubspecialtyを習得することの利点として, 救 急医内で各専門の知識を共有することにより救急診療の 質の向上を図ることができること, 各科専門医の救急疾 患への負担を軽減することができ, 各科との良好な連携 を維持できることが挙げられる。この結果, 救急初療か ら入院までが円滑にすすみ, 救急患者に対し無駄のない 質の高い医療を提供可能な状況にしている。さらに, 救 急医が救急患者の初療のみならず，本人が希望する専門 分野の診療に従事することができ, 救急医の motivation を維持できるといった利点も挙げられる。
表 2 当院救急部のスタッフ構成と subspecialty

- Staff 1 （25）……集中治療*

- Staff 2 (13) ……般外科*, 心臓血管外科

Staff 3 (12) ….. 一般外科*, 心臓血管外科

Staff 4 (11) …... 一般外科*, 心臓血管外科

Staff 5（11）……内科（内分泌 · 糖尿病）*

- Staff 6 (9) …... 中毒

- Staff 7 ( 8 ) ….. 循環器

- Staff 8 (6) ….. 一般外科*

Resident 1 (4) ….. 一般外科

Resident 2 ( 3 )

その他, これまでの subspecialty；総合診療科, 精神科, 呼吸器内科, 放射線科, 皮膚科

・救急認定医または専門医，*各科認定医または専門医， （）内は医師経験年数

\section{2.チーム医療の実践}

当院の診療科は, 現在35科·部門に細分化されており, 前述の如く各専門分野ではそれぞれ質の高い医療を提供 している。しかし, 高齢者の増加や基礎疾患・合併症の 増加に伴い, 疾患の多種多様性を生じて単一診療科では 対応困難な症例も増加してきている。つまり, 専門化 · 細分化する欠点として，このような複合疾患に対する診 療が不十分になるとともに，複合疾患に対応できる generalistの医師育成が課題として挙げられる。

当院では，各科専門医のみでは対処が困難な複合疾患 を有した患者に対し，救急医が中心となりチーム医療を 実践している。もちろん各分野では各科専門医による診 療が理想的であることから各々に治療を依頼するが，各 
科間に扮ける連携が必要となり，全身管理に精通した救 急医が主治医となって適確な舵取りを担い, 全体として の治療レベルの高度化，安全性に取り組んでいる。

現在, 内科系の複合疾患は総合診療科に委ねているが, 外科系疾患は救急部が担当することとし，とくに年間 100 症例以上救急搬送される多発外傷患者に対しては救 急医が中心となりチーム医療を実践している。多発外傷 には外科系各科のみならず，IVRを行う画像診療科や緊 急手術の際は麻酔科も関与している。救急部には外科医 4名 (全員が外科認定医または専門医) が常駐してこれら 外科系各科と密な連携を保って, 緊急手術を含め365日・ 24時間迅速な対応を可能としている。また，多くの多発 外傷患者の診療を担当することにより, 各科の外傷疾患 に対する幅広い知識が得られ，若手医師の外傷外科医と しての育成にも繋がっている。

多発外傷への更なる取り組みとして, 救急医全員が JATEC やPTLS を受講済み（うち 4 名がインストラク ター) であり, 標準的な外傷初期診療が可能で, 初療か ら手術を含めた入院診療までスムースに移行できるシス テムを構築した。また, 胸部外傷, 血管外傷への対応を 強化するため, 3 名が心臓血管外科をローテートして更 なる subspecialtyを習得した。

当院では多発外傷以外にも, 救急医が重症中毒や内因 性外科系疾患で集中治療が必要な患者の診療や, 集中治 療室（ICU）及び高度治療室（HCU）の管理, CHDF や
PMX-DHPなどの体外循環が必要な患者の管理，NST (栄 養サポートチーム) やRST（呼吸サポートチーム）活動 などでリーダーシップを担ってチーム医療を実践してい る。チームで診療することは，患者に有益なのはもちろ んのこと，リスクマネージメントの面からも有利であり， 各科専門医やコメディカルとの連携の強化に繋がるとと もに，専門化しつつある医療の現況の中でgeneralistの育 成にも一役を担っているといえる。

\section{まとめ}

救急患者の増加に伴い, 救急医の不足や過剩労働が問 題になっている。もはや救急医のみで全ての救急患者に 対応することは困難な状況であり，とくに当院のような 大規模急性期病院の併設型救命救急センターでは, 病院 全職員での救急診療への取り組みが必要である。このた めの救急医の役割として, 単なる救急搬送患者の初療の みに終わることなく, 幅広い知識 (generalist) と subspecialtyを習得することにより，各科専門医と密に連携して チーム医療を実践し，その中でリーダー性を発揮してい くことが要求される。その結果として, 搬送される救急 患者に対して満足のいく最善の医療を提供することが重 要である。

当院の経営理念は一We Deliver The Bestーであり, 救 急医が中心となり救急患者にとって常に best care を提供 し続けていくことが救急医の役割であると考える。

\section{SW3-5}

\section{院内医阨は救急医に何を期待しているか？}

\author{
手稲溪仁会病院救命救急センター
}

$\begin{array}{lrrrrr}\text { 森下 } & \text { 由香 } & \text { 伊藤 } & \text { 沙和 } & \text { 山川 } & \text { 一馬 } \\ \text { 亀田 } & \text { 徹 } & \text { 南崎 } & \text { 哲史 } & \text { 早川 } & \text { 達也 } \\ \text { 高橋 } & \text { 功 } & & & & \end{array}$

\section{はじめに}

手稲渓仁会病院は1997年より専任の救急医を置き, 救 急患者全てを重症軽症を問わず受け入れる方式をとって いる。自力来院と救急車来院合わせて年間 2 万人以上来
院する救急患者全てを救急医が診療することは困難であ るため, 当院では, 救急医は救急来院患者でのうち, 緊 急度の高い患者の初療, 及び各科専門医に引き継ぐこと のできない入院患者管理と院内救急対応を行ってきた (表1参照)。2005年 4 月より，ドクターヘリ基幹病院と 救命救急センターの指定を受け, 当院における救急医の 任務はさらに増加したが，救急医が行うべきと思われる 役割を全てこなすためには人員の面では十分とはいえな い状況である。今後, 当院において救急医がどのような 役割を果たしていくべきかを再考する意味で，救急医を 含めた院内全診療科の医師に対し, 救急医に期待する役 割について意識調査を行った。

\section{方 法}

2005 年 4 月の時点で当院に勤務する医師 158 名（救急 専任医 5名, 他診療科医 127名, 研修医 27名)にアンケー 卜を配布し, 提出してもらった。無記名で診療科, 勤務 
表 1 手稲渓仁会病院における救急診療体制（2005 年 3 月現在）

\begin{tabular}{|c|c|}
\hline 病床数（病院全体） & 524 床 \\
\hline \multirow[t]{2}{*}{ 救急患者病床* } & ICU4 床+一般病床 \\
\hline & (4 月より 院内 ICU4 床, 救急患者用 HCU10 床に変更) \\
\hline 診療区分 & 初期 · 二次 · 三次救急 \\
\hline \multirow[t]{11}{*}{ 救急専任医の業務 } & 1. 救急外来業務 \\
\hline & 救急車患者 \\
\hline & 自力患者のうち外因，緊急性の高い患者 \\
\hline & （自力患者の診療前トリアージは救急外来看護師が行なう) \\
\hline & 2. 入院患者診療 \\
\hline & 他科に容易に振り分けられない患者で入院を要する場合 \\
\hline & （例，中毒，多発外傷，心停止蘇生後） \\
\hline & 3. プレホスピタル \\
\hline & ドクターヘリ運営 \\
\hline & 4. 診療以外 \\
\hline & 院内 ICLS コースの開催 \\
\hline \multirow[t]{8}{*}{ 非救急医の救急外来での業務 } & 自力患者の診療 \\
\hline & （内因，緊急性が低い患者） \\
\hline & 院内輪番医（非救急医） (平日 $17: 00^{2} 22: 00$ \\
\hline & 土曜 $\quad 12: 00 \sim 22: 00$ \\
\hline & 休日 $8: 30 \sim 22: 00$ \\
\hline & 当直【PGY2】研修医（22:00～8：30） \\
\hline & 救急医からの依頼があった場合 \\
\hline & 各科当直（あるいは宅直）医 \\
\hline \multirow[t]{3}{*}{ 救急専任医の数 } & 救急専門医 5 名 \\
\hline & 救急研修医 $\quad 1 \sim 2$ 名 \\
\hline & 院内ローテート研修医 2～4名 \\
\hline \multirow[t]{9}{*}{ 院内当直医 $*$} & 救急専任医 $2 ４$ 名 \\
\hline & (スタッフ1名十研修医) \\
\hline & 当直研修医 2名 \\
\hline & 循環器内科医 1 名 \\
\hline & 消化器内科医 1 名 \\
\hline & 脳神経外科医 1 名 \\
\hline & 小児科医 1 名 \\
\hline & ICU 当直医 1 名 \\
\hline & 4月より 外科医 1名 が追加 \\
\hline
\end{tabular}

* 2005 年 4 月 救命救急センター指定後に変更が加えられている

年数を記入することとした。アンケートの質問項目は下 記の通りである。

・当院の救急医は十分な役割を果たしているか (選択)

・救急医が行うべき役割（自由に回答）

·救急医が行う必要のない役割（自由に回答）

\section{結果}

33名よりアンケートを回収した。その内訳は救急専任 医 3 名，他診療科医 24 名，研修医 6 名であった。

表 2 に救急医が十分な役割を果たしているかという質
問に対する回答のまとめを示した。十分な役割を果たし ているという回答は 33 名中 10 名であった。このように 回答した医師は, 研修医 1 名と, 救急以外の診療科医師 9 名であり, 救急業務担当の経験のある医師は 1 名のみ (研修医)であった。これらの医師の当院での勤務年数は 10 年以上 3 名, $3 \sim 10$ 年 3 名, 3 年以下 4 名と, 明らか な傾向はみられなかった。

次に，救急医が行うべき役割を表 3 に示した。救急医 の意見と救急以外の他診療科医師（非救急医）の意見を まとめた。研修医の意見は救急業務経験があるというこ 
SW3 救急医の役割

表 2 救急医は院内医師の期待する十分な役割をはたしているか

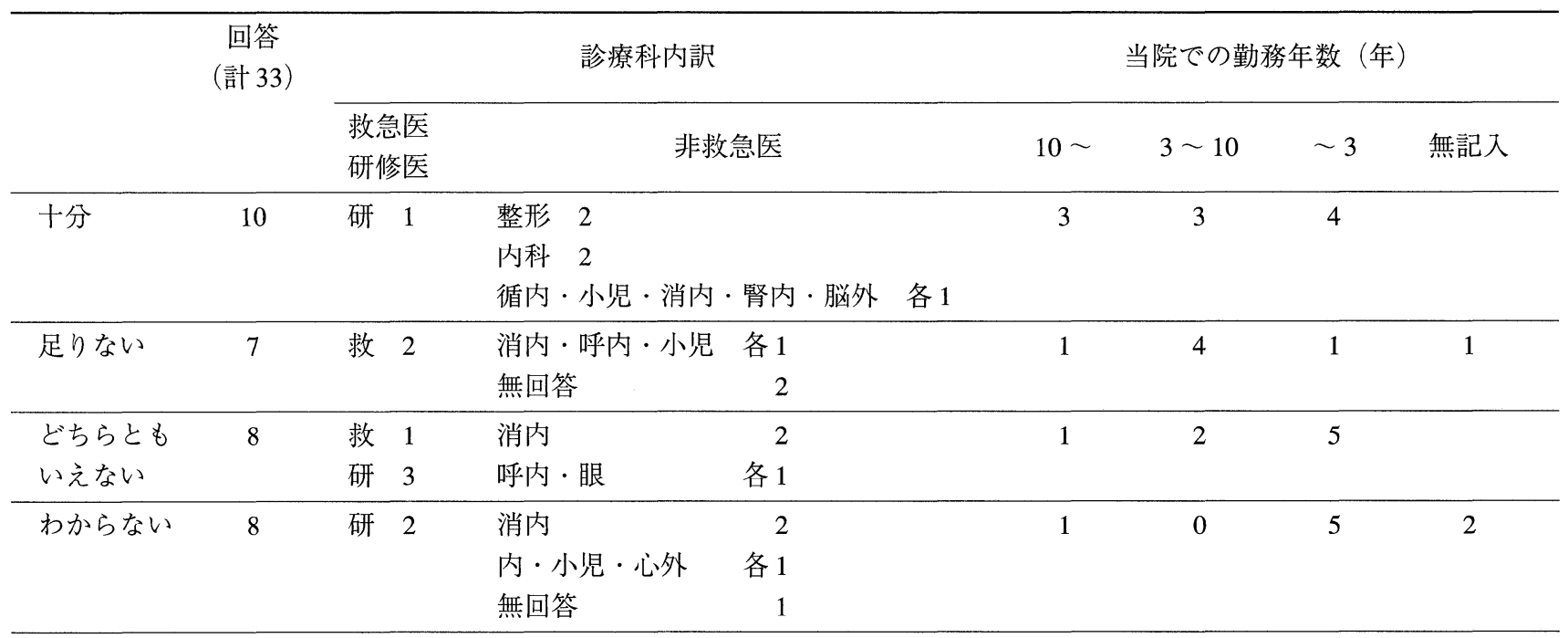

表 3 救急医が行うべき役割

\begin{tabular}{|c|c|c|}
\hline & 救急医 - 研修医の意見 & 非救急医の意見 \\
\hline $\begin{array}{l}\text { 現在, 当院の救急 } \\
\text { 医が行っているこ } \\
\text { と }\end{array}$ & $\begin{array}{l}\text { - 救急車来院患者の初期対応 } \\
\text { - 外傷, ショック, CPAの初期治療 } \\
\text { - ドクターヘリ, プレホスピタルケア } \\
\text { の積極的な関与 (救急隊のための講習) }\end{array}$ & $\begin{array}{l}\text { - 救急車患者の初期治療 } \\
\text { - 院内救急の対応 } \\
\text { - 救急処置及びトリアージ } \\
\text { - 院内 ACLS の啓蒙 } \\
\text { - 救急部的な疾患（溺水など）の初療・入院治療 } \\
\text { - 他診療科で担当医が決まっていない救急患者の入 } \\
\quad \text { 院管理 } \\
\text { - 全てのwalk in 患者のトリアージ（実際は主に救急 } \\
\text { 看護師の業務） } \\
\text { - プレホスピタルケア（主に, ドクターヘリ) }\end{array}$ \\
\hline $\begin{array}{l}\text { 現在は全てを救急 } \\
\text { 医が行うことがで } \\
\text { きず, 大部分を他 } \\
\text { 診療科医師に依存 } \\
\text { している }\end{array}$ & $\begin{array}{l}\text { - 救急来院するWalk in 患者全てにかかわ } \\
\text { る } \\
\text { - 研修医の救急診療全てを監督する } \\
\text { - 救急外来から他科に入院したが, 全身 } \\
\text { 状態が安定しない患者に対する入院初 } \\
\text { 期の全身管理（急性期病棟〔HCU〕の } \\
\text { 管理） }\end{array}$ & $\begin{array}{l}\text { - 救急外来に来院する全ての walk in 患者の診察 } \\
\text { - 研修医が診察した救急患者の最終確認 } \\
\text { - 救急から他科に入院したが, 全身管理が必要な患 } \\
\text { 者の全身管理（救急入院患者の初期集中治療） }\end{array}$ \\
\hline $\begin{array}{l}\text { 現在はまったく行 } \\
\text { われていないこと }\end{array}$ & - 熱傷患者の管理 & $\begin{array}{l}\text { 一一般市民に, BLSや救急受診が必要となる症状な } \\
\text { どを啓蒙すること }\end{array}$ \\
\hline
\end{tabular}

表 4 救急医が行う必要のない役割

\begin{tabular}{ll}
\hline 救急医の意見 & $\begin{array}{l}\text { - 問診や救急隊からの情報などから疾患が明らかと思われる患者の診療 } \\
\text { (最初から各診療科での診療が適切では? ） }\end{array}$ \\
\hline 研修医の意見 & $\begin{array}{l}\text { - 入院患者の管理（外来と掛け持ちでは, 必要時に対応できない) } \\
\text { — 小児の風邪, 下痢などの診療 }\end{array}$ \\
\hline 非救急医の意見 & - 内因性疾患の walk in 患者の対応 \\
\hline
\end{tabular}


とで, 救急医の意見に含めた形で表した。これらの意見 を, 現在当院の救急医が行っている役割と, 救急医が 行って扔らず非救急医に依存している役割, 当院では 行っていない役割に分類して整理した。

救急医が行うべきと考えられる役割のうち, 現在当院 の救急医が行っているものは, 救急車患者の初期対応, 救急的疾患 (外傷, ショック, CPA, 溺水) などの初期 対応, ドクターヘリ事業などは, 救急医, 非救急医の両 者の意見としてみられた。院内救急の対応, 院内 ACLS の啓蒙, 救急来院患者のトリアージなどは, 現在救急医 が果たしている役割で, 非救急医から救急医の行うべき 役割として指摘されているのだが, 救急医の中からは, とくに指摘のなかった役割であった。

救急医の行うべき役割の中で現在は非急球医に依存し ている役割としては, 救急外来に受診する自力来院患者 の全てにかかわること, 研修医の救急診療全ての監督や, 救急入院した患者の急性期管理などが, 救急医, 非救急 医の両者より指摘されていた。

さらに，救急医が行うべきだが，現在は当院ではまっ たく行っていない役割として, 救急医からは熱傷患者の 管理が, 他科医師からは, 一般市民の救急に関する啓蒙 が指摘されていた。

救急医が行う必要のない役割について表 4 に示した。 救急医, 研修医, 非急救急医の意見に分類して示したが, 救急医・研修医・非救急医のいずれからも, 来院手段が 救急 (救急車あるいは救急外来) であっても, 緊急性に そしい病態や，診療すべき科が明らかな場合については， 救急医が診療する必要がないという意見がみられていた。

\section{考察}

今回の意識調査では, 当院に勤務する医師 158 名中の 33名からしか回答が得られず，院内医師全体の意見を必 ずしも反映したとはいえないかもしれない，しかしなが ら回答されたものからは, 救急医の行うべき役割につい て, 救急医・非救急医両者とも, ほぼ同様の意見がみら れた。

回答にみられた救急医の役割を総括すると, 救急診療 の質をコントロールし, 初期治療・全身管理に主にかか わり，専門的治療へスムーズに引き継ぐ立場をとること を期待されている役割であるという印象を受けた。さら に，院内における診療のみならず，救急医療に深くかか わる病院前治療や, 救急処置について医療従事者や一般 人に対する啓蒙を行うべきたという意見が非救急医の側 から聞かれたことは注目に值すると思われた。

今回の調査では, 救急医がその役割を十分に行えてい
ないという回答が多くみられたのだが, 行えていないと 考えられる役割には，重症救急患者の入院初期における 管理, 自力来院する救急患者などの研修医の診療の監督, 救急患者全体を掌握することなど, 現在非救急医に多く の部分を依存している業務であった。これらの中には, マンパワーがゆるせば，救急医が行うことが啇している 役割もあるが, 軽症で担当科が明白な症例の初期診療な ど，必ずしも救急医が行う必要がないと考えられる役割 も含まれ，院内の事情に合わせて検討していく必要があ るだろう。

歴史的には, わが国における救急医療は, 通常の医療 機関では診療が困難とされる, 外傷やその他の重篤な病 態の初療とその後の治療, つまり, いわゆる「3 次救急」 に重点をおくことから始まった。このようなシステムに おいて, 救急医は, 3 次救急医療施設における救急患者の 初療から入院治療全般, すなわち, 蘇生などの救命救急 処置, 多発外傷の初期治療にかかわる緊急手術手技や, 集中治療を行っていたのだが，このようなシステムの中 では, 一人の救急患者の治療が救急医のみから構成され るチームで完結されることも稀ではなかった。また，こ のような救急システムでは, 独立型の救命センターはも ちろん, 院内併設型の救急部門においても, 救急部門は 院内の他診療科とほほ独立した形で診療を行っていたた め, 救急医と他診療科医師が意見交換を行う機会や必要 性はあまりなかった。

これに対し，当院では，救急患者の初療を救急医が担 当し，その後の専門性の高い治療をそれぞれの専門科医 師に引き継ぐという, いわゆる「ER型救急システム」を とっている。このシステムでは, 救急患者の診療は救急 医のみによって行われるわけではないため, 病院全体が 救急患者を受け入れる体制がなければ成り立たないもの である。救急医は, このようなシステムの中では, 従来 の3 次救急システムのように患者一人一人の治療を完結 するのではなく, 病態に応じた治療が一人一人の患者で 遅滞なく行われるように管理するというような, 救急診 療の質を保つ役割を果たすことが期待されていると考え られる。

「ER 型救急システム」自体は, わが国で行われるよう になってまだ新しいものであり，救急医・非救急医とも に,これをどのように運営していくかはまだ模索状態と いっても過言ではない。新しいシステムの中で, 救急医 がどこまでの役割を分担するのが適切かは医療機関の構 成などによっても，必ずしも同一とは限らない。今後も， このような意識調査などを通して, 救急医の行うべき役 割を検討していく必要があると考えられる。 


\section{結 語}

今回,「ER 型救急システム」によって運営されている 医療機関において，救急医の役割に対する意識調査をお こなった。この調査から, 救急医は, 救急診療の質のコ ントロール, 救急患者の全身管理, 病院前救急, 救急処 置の啓蒙などの役割を期待されていることが明らかに
なった。現状において救急医がどのような役割を果たす べきかは，医療機関の体制や，救急医のマンパワーに よって異なるものであるが，当院のように病院全体とし ての救急応需体制を持つ医療機関では，救急医と非救急 医が能率的に協力しあう必要があり，このような意識調 査を通して，救急医の受け持つべき役割を検討していく ことが重要であると考えられた。

\section{SW3-6}

\section{一般救急病院における救急医の役割}

- specialist でありかつ generalist である救急医の重要性一

1 京都九条病院脳神経外科, ${ }^{2}$ 同院救急科

榊原 毅彦1 平井 誠 ${ }^{1}$ 瓦莫健太郎 ${ }^{1}$

松井 淳琪 ${ }^{2}$ 松井 道宣 ${ }^{2}$ 山木 垂水 ${ }^{1}$

\section{はじめに}

現在のわが国の救急医療体制に㧍いて，全ての三次救 急患者を救命救急センターにて診療することは不可能で あり, 地方においてその傾向は強い。多くの場合, 救急 専門医指定施設等の一般救急病院にて一次救急から三次 救急までの診療にあたっている。そこで, 一般救急病院 である当院での救急体制を検討し, 救急医の役割につい て述べたい。

\section{病院の概況}

京都九条病院は, 京都市南区 (人口 98,905 人) にある。 2006 年 4 月現在当院は 207 床の急性期病院として内科, 消化器科, 循環器科, 一般外科, 整形外科, 脳神経外科, 麻酔科, リハビリテーション科にて構成され，常勤医は 20 人で全員日本救急医学会会員である。そのうち専門医 は4名抒り，救急科専門医指定施設となっている。また， それぞれの科のほとんどの医師は所属する学会の専門医 である。

\section{当院の救急体制}

救急患者の受け入れに関しては，小児科，産科救急以 外は前述の診療分野を中心に基本的に要請があればいか
なる患者であろうと，とにかく全て受け入れる体制を とっている。夜間, 休日の当直は外科系 1 名, 内科系 1 名で少なくともいずれかの医師は常勤医である。また平 日の午後 9 時までは救急患者のためにさらに 1 名の医師 が待機している。また各科ともに完全on call体制をとっ ており，夜間，休日の緊急性のある疾患にも十分対応で きている。当院の救急車の受け入れ状況は表 1 に示す。 2001 年より年々増加傾向にあり, 現在およそ年間 1,800 名である。そのうち入院を必要とした症例は約 $45 \%$ 前後 であった。

\section{当院の救急医療に対する考え方}

われわれの病院における救急医療における理念は「医 師を中心に職員一同が，われわれの病院がいわゆる地域 の中核的救急病院であるという自覚をもち, 来院する救 急患者にいかに貢献できるかという意識を持ち続けるこ と，そのために，常に医師をはじめとして職員全員によ る協力体制を持つ。ということである。また当院の医師 の救急医療に対する基本姿勢は「各分野の specialist であ ると同時に generalistであれ」ということである。これら の考え方を具体的に実践する方法を紹介する。

そのひとつは，全ての医師はいかなる救急患者の搬入 時には時間と状況が許せば必ず一度は救急室に集合する というシステムである。当院では救急患者の搬入依頼は 事務段階で基本的に全て断らない。救急患者の搬入が決 定すれば院内放送で（夜間は当直医に直接伝える）「業務 連絡990または999」と流す。990の場合はいわゆる救急 患者が搬入されることを意味し，999 は心肺停止状態や

表 1 Number of patients who were transferred by the ambulance.

$\begin{array}{lll}2001 & 1450(643: 44.3 \%) \\ 2002 & 1572(704: 44.7 \%) \\ 2003 & 1780(790: 44.4 \%) \\ 2004 & 1873(890: 47.5 \%)\end{array}$




\section{シリーズ・ワークショップ}

それに近い患者が搬送されてくることを意味している。 各科の医師が搬入患者に対する初期治療を協力しながら 迅速かつ適切に行いその後に担当する専門科を決定し, 専門性の高い医療を行うこととしている。また，多発外 傷などの複数科の協力が不可欠な場合も協力体制はス ムーズである。これらのシステムにより preventable death の症例は減少できていると考えている。心肺停止患者の 搬入時に際して原因のいかんにかかわらず最も必要なの はマンパワーである。このような考え方が実践されてい る現状では多くの医師, 看護師等の医療従事者が集合す るようになった。また，院内の急変患者や救急患者の発 生に対しても院内放送にて「トリプルコール（発生場 所）」と流すことにより多くの医師が院内の緊急事態に対 応できるようにしている。こうした体制により多くの医 師が自分の専門外である部分の疾患に対しても知識が増 え, generalist として適切な初期治療が日中夜間を問わず 行えるようになってくる。

もうひとつの当院の行っている方法は，日曜祝日を除 く, 毎日, 朝 8 時45分から, その日勤務する医師が全員 集まり前夜の当直の医師から当直業務中に起こったでき ごとの申し送りをうける。その際に入院患者に対する担 当医も決定される。また当日の手術予定や検査予定も申 し送られる場合もある。これらの申し送りの時にそれぞ れの疾患に対する discussion が行われ，これらにより各 医師が共有できる知識ができてくる。この時間が当院に おける generalist となるべき働きかけとして重要な部分を 占めていると考えている。

また，他部門(看護部，画像診断部，臨床検査部，生理 検査部, 臨床工学部, リハビリテーション部, 医事部等) との協力関係は非常に重要であり協力体制を図るために 救急医療に対する勉強会等を開催し啓蒙に努めている。

\section{考察}

現行の日本の救急医療体制において, 救命救急セン ターにて全ての三次救急患者を診療することは不可能で ある。とくに地方においてはなおさらである。そこで当 院のような地域の中心的な一般の救急病院においては多 くの科の医師の協力体制が必要不可欠になる。そこで各 科の医師に対して自分の専門分野の specialistであると同 時に救急医としての generalist であるべく多くの働きかけ を行い，そのように日々実践している。すなわちわれわ れの病院において救急医とは全ての医師のことであり, 救急患者治療に際しては多くの医師で初期治療を行った 後にそれぞれの専門分野の治療にスムーズに入れるよう にしている。また，患者のトリアージも自然に行えるよ うになり必要に応じて三次救命救急センターへの搬送も 間髪をいれずに行っている。また全ての医師がこのよう な考え方であるため, 病院内のほかの部門 (看護部, 画 像診断部, 臨床検査部, 生理検査部, 臨床工学部, リ八 ビリテーション部, 医事部等）にも救急医療に対する考 え方が浸透し, 協力, 信頼関係のもと救急医療に携わる ことができている。

一昨年より行われている臨床研修医制度の主たる目的 は，まさにわれわれの病院の医師が日常的に行っている ものに他ならないのではと考えている。

このような「救急医療に携わる医師は specialistである と同時に generalistである。といった考方方が多くの病 院の医師に浸透することにより，それぞれの地域の救急 医療体制は改善されるのではないかと考えられる。

\section{結 論}

一般救急病院における救急医は，専門性を有した上で救 急医療に携わっていることがほとんどである。そこでの救 急医の役割, 考え方は, 救急に携わる医師は「 specialistで あると同時に generalist である」といったものであると考 えられる。

\section{DSSCUSSDON}

座長 岡山大学大学院医歯薬学総合研究科救急医学専攻 氏家 良人 鳥取大学医学部救急災害医学 八木 啓一

八木「救急医の役割」のワークショップですが, 役割と言 うからには，今度は枠組みのなかでの役割というふうに考え るべきかと思います。「救急医療の枠組み」のセッションで
は，これから先はかつての完結型ではなく,やはりER型の方 向に進むというご意見でした。ただし地域あるいは院内の状 況によっては，少しずつバリエーションもあるだろうという 方向だったかと思います。話題の進め方として, 現状を確認 して, どんな問題点があるか, それに対する現実的な解決法 と,できれば将来像をまとめたいと思います。もう一度確認 しますが，まず完結型でされているところは，札幌医大とい うことでよろしかったですね。ER型とおっしゃいましたが， 
ほとんどのところはウォークインの患者に関しては，ほかの 流れで診て頂くところがあるということでよろしいですか。 ウォークインまで全部自分たちでやってしまうというところ はありますか。

榊原うちの場合は誰が救急医かというのは，そのときど きで変化します。いわゆるウォークインに関してはその時間 帯の担当医が決まっていますので，その人が対応するという 形です。

八木 あとは初期治療あるいは処置や手術の担当ですが， 初期の治療あるいは振り分けだけだというところは, 手を挙 げて頂けますか。どちらかといったら, 振り分け, 初期の治 療，あるいは最終的な手術のところまで担当されるというと ころはいかがですか。あとはそうすると入院のほうですね。 手術したところは全部, 自分のところで主治医として受け持 つというところは, どちらでしょうか? 外科的なところは? ○外傷だけは最後まで診ます。

八木手稲渓仁会は?

森下手術するのは外科とか整形です。ただ外科は全身管 理できるのですが，整形などは全身管理できない場合もある ので，そういう場合はこちらが面倒をみるときもあります。

八木集中治療の部分に関しては, どちらの施設も救急医 がされているということでよろしいですか。

森下手稲の場合ですが，ICUの当直医というのがいて，う ちのICUはクローズドタイプです。ICUの専門医もいますの で，院内のICUに入った患者はそちらのほうで全身管理を やってくれます。ハイケアユニットのほうが不在なので, や りたいとは考えていますが，全部は手が回らない状況です。 八木 あとは集中治療から手が離れて，一般病室に移れる という状況のときに，手を離してしまうという施設はどちら ですか。手を挙げて頂けますか。そうすると退院のところま で面倒をみる。大抵のところはそういうことでよろしいです か。それと今回の発表施設は, どちらかというと院内の協力 が非常にいいところばかりです。他科が比較的協力してくれ るところばかり集まってしまったと思いますが，全国的には 他科の協力が得られなくて, 非常に困っているところがある のではないでしょうか。あるいはウォークインの患者に関し ても，救急医が診ないといけないという状況のところも多く みられるのではないかと思いますが，今回はそういうところ はないようです。他科の協力が非常にうまくいっているし， ウォークイン, 初期救急に関しては, ほかの先生方にどちら かというと気前よく診て頂けるということでよろしいですか。 二宮 日本医大多摩永山病院の二宮です。黒川先生のあと を引き継いでいます，黒川先生がいなくなって非常にいじめ られるんです。たとえば救急の原則として，黒川先生は断ら ないということで全部受ける。ただし他科の，特に内科の当 直の先生はほとんど断りたい。非常にギャップがある。今度， 内科の部長先生が院長になられて,「内科の当直医は夜は寝る んだ。昼間の外来は忙しいから, 救急は一次から三次まで, す べて 2 人増やすから救命で診ろ」ということになったんです。 そうするとこれは完結型と言えば完結型だし，ERと言えば ER だし，スタッフ 7 人では一次から三次まで一晚に 50 人も 100 人も診て, 三次救急でクリッピングの手術もしてという
ことは, 集中力の維持というところでクオリティを保てない んです。ほかの病院もあるから, 黒川先生もその 4 病院の院 長の一人ですので責任はあると思うのですが，あとに残され た者の辛さというか, そういうこともちょっと考えて頂けれ ば, 先ほどのところの 4 番目くらいに出るのではないかと 思ったりしています。（笑）

氏家 日本救急医学会がつくる救急医としては, やはり ER に関与する必要があるだろうと思います。ただその関与は, 実際に一次の患者をすべて診るという関与の仕方なのか, そ うではなく先ほど京都の榊原先生がおっしゃいましたが, 救 急の一次患者を診るというのは医師として当たり前のことだ。 救急医でなくても，医師であれば誰でもがそれをやる。それ に対する教育を救急医が担うという必要はあると思います。 たとえば岡山大学だったら一晚に 10 名とか 15 名ですから救 急医が診てもいいのですが，50名，60名来るところで，果た して救急医の専従医がそこを全部やるかどうかというあたり についてはどうですか。

八木 昨日もそういうお話が評議員会でもあったのですが, 夜の当番のほうにされてしまうのではないか。ER的なところ をみると, 非常に多様な感じで診られるので, 若い人にとっ て勉強になるし，やりがいがあるという意見もあります。や やもすればほかの科が引いてしまって，夜の当番を救急医が させられるという形にもなりかねないという意見もあります。 今日集まって頂いた方はそういうことで困られていることは あまりないようですが，フロアの方で，そういうことで困ら れた方はいらっしゃいますか。

上山社会保険中京病院救急の上山です。うちの場合は ウォークインを含めて年に 25,000 人くらい来ます。当初は全 部の患者, ウォークインの患者の病歴から救急医がとってい たのですが，少ないスタッフで重症の患者と同時にはできな いから, いかにして軽傷の患者を救急部から切り離すかとい うことが, われわれの15年の歴史でした。結局, ウォークイ ンの患者はいまは別系統で内科当直と外科当直が診ています が，実態は研修医がファーストタッチをするものですから， 呼んでもなかなか反応が悪いし, 全部別のところで内科当直 と外科当直がうまくいっているわけではない。来年から計画 をしているのですが, ウォークインの患者をうまくコント ロールするのは，研修医ではない若手をうまく入れる。たと えば $3 \sim 5$ 年目のレジデントクラスが呼ばれてくるのではな くて, 初めから救急外来にいて管理をするという方式を頭に 描いています。次の問題は, そういう全体の救急外来の管理 を救急医がするのかしないか。すると，たしかにクオリティ は上がると思いますが，たとえばトラブルがあった場合，そ の責任は外科系の当直医なのか, それとも監督をしている救 急科の部長が責任を負うのかというところまで考えますと, やはり診てからある程度軽傷とわかった場合は, 救急医以外 の部門で責任を負ってもらうというのが, 非常にスムーズに いくと思います。そこがポイントになるのではないかと思い ます。

八木 ありがとうございます。若い人に診させるというこ とですね。

田代熊本赤十字病院の田代です。私どもの救急部でも ER 
型としてウォークインがだいたい 6 万人で, 救急車での患者 が 6,000 人弱だと思います。日勤带の夕方 5 時までは救急部 でウォークインも救急車も診ますが，夜間だけは救急車のほ うを救急部が対応して, ウォークインのほうは各科の当直の 先生に任せている状況です。本来なら，できれば夜間の ウォークインも救急部で診たほうがいいとは思うのですが, そこで一つ問題になってくるのが，やはり ER型と言いながら も, CPA, 中毒, 熱傷などは, 救急医が入院患者さんを持つ 状況がある。本当にER型を目指すのだったら，極論ですけれ ども，入院患者さんは持たないというイメージでやっていか ないと箃しいのではないかと思いますし, 実際にそれをやっ ているER 型の病院は日本全体でまだ少ないのではないかと 思います。

杉本救急患者さん, ウォークインを含めてどうするかと いう問題ですが, 日本で発生している救急の受診患者, 初療 患者は年間 2,500 万人前後だろうと思います。いま救急医とい うのは救急科の専門医あるいは認定医ですが, 彼らが診ると したら 1 人で 2,700 人くらいでしょうか。このなかで必ずし も救急をやられていない人もいらっしゃいますから, 救急医 1 人当たりが年間約 1 万人の患者を診るという計算になりま す。そうなると果たして 1 日何人くらいになるのかは計算す ればわかると思いますが，30４0人の患者を診れば，いいの ではないかと思います。ただ，それは24時間にわたって診な いといけないということになってくるかと思います。この辺 のことをどうするかという問題と, 片一方で医師の数は 25 万 人います。それを全員というのはなかなか難しいでしょうか ら，比較的若い人たちということで10万人くらいの医師がか かわって初療患者を診るとすれば，かなり簡単に診られるだ ろう。だからおそらく現実的な問題としては, 各科の先生方, 要するに救急の専門医以外の人たちを含めて診ていくほうが, 㧈そらくみんなとしてはいいというか，疲れてしまうよりは， いい医療が提供できる。それはどういう形か。たとえばいま の卒後研修が始まってからは, 比較的いろいろな初期救急も やろうではないかとなっていますが，ある年齢以上，おそら く卒業して20年くらい経っている人たちは，なかなかそうも いかない。非常に専門分化してしまい, そこで自分の好きな ところだけやりたいというところもありますから，その人た ちを引き込むことは拉とらく難しいのではないか。ただし若 い人たちに対しては，救急の専門医と言われる方がどういう 形で指導していくか, 救急部としてシステムを管理していく ことを考えるのが現実的ではないかと思います。

八木若い人に診てもらうというのと, あるいは各科の先 生方, 氏家先生も言われましたが, 医師として当然だからと いうことで, 分担してやって頂く。これが筋ではないかとい うご意見もあります。

氏家もちろん一般のドクター, 非救急医でも診るべきだ と思います。ただそれに対する教育, 標準化した教育という ものについて救急医が関与しないといけないと思います。こ れまでそういうものに対する日本救急医学会の取り組みは少 なかったような気がします。ただ指導できる救急医はつくっ ていかないといけないと思います。そうでないと，ただ拍 せしているだけですから，救急医のアイデンティティ自体が
ないということになります。

八木私としてはそれだけではなく,やはり病院の管理者 というかトップが各診療科の先生に担当しなさいということ を強力に言ってくれないと, 進まないのではないかと思いま す。われわれが指導したくても，ついてこなければ，踊って くれなければしょうがありませんので, 救急医学会として方 向を出すべきではないかと感じます。ウォークインの患者に 関してはいかがでしょうか。

黒川 ER型でやるかどうかというのは, やはり各施設の状 態によると思います。ただし, 救命部のドクターが非常に豊 富で，何でもできるという施設はまずないと思います。それ から今後の見通しから言っても, 救命救急センターに入って くる医師の数が減るのではないかということが懸念されてい る状態ですので, やはりどの救命部も厳しいことは間違いな いと思います。けれども，杉本先生が言われましたように，新 しい卒後研修制度からして，いわゆる一次救急，場合によっ ては二次救急まで救命救急センターが診なければならないと いうのは明らかだと思います。ではどうやってそれを診てい くかということで，私どもはいままで各科が対応していた一 次救急あるいは二次救急はぜひ㹉いしたい。しかし，たと えば外科が手術をやっていて，あと 2 時間は手が空かないと 言っているときに，小児外科の患者さんが来たときに，断っ てしまうよりは, 救命部が「いま手が空いているから，診て あげよう」。それからたとえばめまいを訴える患者さんが来た ときに，耳鼻科に言うと「それは脳外だよ」。脳外に言うと「そ れは内科じゃないの」「いや, 眼科じゃないの」。結局, ああ たここうだ言っているうちに患者さんは怒って州ってしまった， というケースもなきにしもあらずです。そういったときに 「いいよ。そういうケースは診られるからね」という感じで救 命部が対応する。それを私は「補完する」と言っているんで す。そういうことをやることによって，ほかの科と救命部，あ るいはその逆とか，いわゆる双方向型の協調協力が得られる。 つまり院内の風通しがよくなるという効果が十分に得られる と思います。そういうことで私はあえて「一次救急外来は全 部, 救命部がやる」ということは宣言しないつもりです。少 ないスタッフで，できるわけがないですから。それよりも「君 らも診ろよ。俺らも助けるよ」という形が必要だろうという のが，私の発表の趣旨です。

榊原京都九条病院ですが, 先ほど八木先生が拐っしゃら れたように，うちのいまの救急体制は少し変わっていると思 います。成功した理由は, 院長がここの救急医学会の評議員 でもあり，強力にその体制を敷いたからです。それに合わな い医師は，大学の医局から怒られて自発的に出ていかれる。 一つのチームとしてできるようになってきたというのが，大 きな役割だったと思います。どういうところでも，トップが 病院や診療に対してどういう考え方を持って，どういうふう にやっていくのかというのがもっとも大切だろうと実感して います。

八木 どちらかというと軽傷の患者の受け入れに関しては, だいたいの方向性を出して頂いたと思います。次に重症を受 け持っていて自分たちのモチベーションとか, それだけを やっていると将来的に心配だというお話がそれぞれの先生方 
からありました。こういう問題点がありますということをも う一度，手短にお願いします。

奈良重症に関しては発表でも言いましたが，仕事をする 分には十分満足して，かなりやりがいがあるとは思っていま す。ただ学生や下の者から聞かれます。「先生，いつまでやる の」。逆に言えば,「先生がいるから，僕たちは居場所がない」 とか，限られたスタッフということがありますから，そうい う問題はあると思います。北海道の別の救命センターで求め られている救急医像というのは，実はそういう医師ではなく， もう少しジェネラルな医療ができる人です。そういうなかで ちょっと悩みはあります。

八木完結型で三次, 重症だけを扱っているところで, 大 規模な病院で働いている限りにおいては，それで満足できる のですが，それぞれの地域の病院に行くと，そぐわないよう な感じがするというジレンマがあるということをおっしゃい ました。先生のところはどうですか。

弥永亀田総合病院の弥永ですが, 当院ではやはり救急が 集中治療の多くを担っています。急性期はいいのですが，そ のあと軽傷化してきたときに，どこまで救急科がかかわるの かというので，毎症例ごとに迷うところがあります。どのく らいの状態になったら各専門科に引き継いでいくかが不明確 で, 結果的に救急科の入院業務が非常に膨らんでしまって, 疲労につながってしまう。そういうことが大きな問題ではな いかと考えています。

八木 先生は発表で，最終的に自分たちの目指すべき像が よく見えてこないということをおっしゃられたような気もし ますが。

弥永当院の救急医は非常に若い人間が多くて, ここで 育って 10 年後, 20 年後にどういう姿になっているかというの がイメージしづらい。サブスペシャリティに関しても, 救急 医がサブスペシャリティを持ってモチベーションを維持する というのは何となくわかるのですが, 当院の場合は各専門科 が常にバックアップでいるので，患者さん側に立って考える と, 毎日専門の診療をやっている医師に診てもらったほうが 結果的にいいんじゃないか。救急部に所属しながら手術を やっても，やはり経験数に差が出てくると思います。そうす ると専門医に任せるところは任せる。そのサブスペシャリ ティをどうやって実際の診療に活かしていくのかというのが, いま㗢いていて見えづらいと言えば見えづらい。実際にサブ スペシャリティを持って働いている医師も救急部には少ない。 八木 麻生飯塚病院の中塚先生のところでは, 必ず何らか のサブスペシャリティを持たせる方向でやっているとおっ しゃいましたけれども。

中塚幸いにも症例が多いので，2〜3 年，初療をします と, ほとんどの疾患の初期診療ができるようになって, 若干 不満が出てきます。もう少しやりたいとか, 最後まで患者さ んを診たいということも場合によっては生じてきますので， サブスペシャリティということで他科をローテートさせてい ます。発表でも申し上げましたが，100\%帰って来いとは言っ ていません。たから外科半分, 救急半分でやって, 救急疾患 の外科の患者を外科として担当してもいいというふうに，そ の辺はかなり融通を利かせています。そういった意味ではサ
ブスペシャリティを持つということはよいことではないかと 思います。

八木 いかがでしょうか。では救急だけではだめですかと いうことは，いつまでも救急だけでは寂しい......。

$\bigcirc \bigcirc$ 私は最初からそうでしたので，あまりサブスペシャ リティにはこだわっていません。サブスペシャリティという のは何を指すのかがよくわかりませんが，何かの専門医にな るということなのか, 自分の興味があることをやるというこ となのか。もちろんうちにも脳外科の専門医になって戻って きて, いま救命センターで働いている者もいます。救急医の 定義は難しいとは思いますが，救急医療一本だけでも別にい いのではないかと考えます。もちろんその守備範囲としてク リティカルケアがあったりもしますが，いま自分の仕事の内 容を考えると，このほかに救急隊員教育とか $\mathrm{MC}$ とかいろい ろなことがあって, 結構十分な仕事量はこなしているのでは ないかと思います。

八木 森下先生は, 救急医のスペシャリティとして集中治 療があるというご意見だったと思いますが，いかがでしょう か。

森下スペシャリティとしてという意味ではなく，救急医 は集中治療ができて当然であると考えています。やはり初療 に重症患者を診るので，集中治療の知識がないと結局，初療 で失敗すると思うので，サブスペシャリティというのではな く, 救急医はやはり集中治療ができて当然です。そういう意 味で振り分け医だけに終わってしまう救急医というのは不満 かなという意見が，われわれの意識調査でも出ました。われ われも余裕のあるときは，整形の患者の全身管理を手伝った り, 呼吸器科で喘息重積の患者の最初の治療を手伝ったりと いうところで荷担していくと，そういうところで救急に協力 してほしいという院内からの要望も出てくる。そういう意味 でサブスペシャリティとは言わないのですが，私は救急医は 集中治療ができないといけないと思っています。

八木 結局, これはわれわれのアイデンティティとか, モ チベーションを持ち続けるとかいうところにかかわってくる のかと思います。京都九条病院の先生，いかがですか。先生 は少しお立場が異なると思います。

榊原明らかにうちの病院は立場が違うと思います。その 分いろいろな意味で忙しいし, ほかの科の先生の協力があり ます。この間も肝損傷, 脾損傷の人のインターベンションを するときは, 循環器科の医師がシースも入れカテも入れなが ら，外科医はまずムンテラをする。その時間がもったいない ので, 循環器の先生がそういうシステムを構築させて, すぐ できるように準備をする。システミックにはわれわれが診る ような体制をやっている。脳外科で脳腫瘍をやっていたら, もう一人外傷が来れば，一人の専門医がおりて，外科医と一 緒に頭を開けるようなことが普通にできています。だからそ のスペシャリティのなかで，ほかのチームに対してどれだけ 貢献できるか, それぞれの救急の患者を診たときにどれだけ 貢献できるかを最大限出してくれているというのが，われわ れのチーム医療として一番やっているところです。それがで きているところはいいのですが，いまのわれわれの問題はマ ンパワーです。やはりもう少し人員が欲しい。もう少しいれ 
ば，もっといろいろなことが.......

（録音中断）

八木 黒川先生，いかがでしょうか。

黒川 トップとしては, ドクターが何らかの特徵というか サブスペシャリティを持っていたほうが使いやすいというか, 救命部全体の力としてはあるように思います。ですが，これ を揃えなければならないと考えてしまうと, 非常に厳しいも のがある。ですから院内には別に専門科がいっぱいいるわけ ですから，そういう人たちの力を結集するということに尽き ると考えています。

○○榊原先生に扔聞きしたいのですが，先生のところは いろいろな科の先生が扔られて, ジェネラルなこともやられ るのですけれども，いわゆる救急専従医がいない。先生の病 院で求められる救急医というのは, 先生ご自身としてはどう いう救急医が欲しいのですか。

榊原もし専従医に来て頂くときに，たとえば何人かの先 生でチームで来て頂けるのだったら，そこで一緒に救急部を 立ち上げてもらって, 専従医としていろいろな救急をみて, そこでわれわれがスペシャリティとしてかかわれれば, ジエ ネラルな部分を診て頂けるということがあります。たとえば 救急の専従医に一人で来て頂いても, 同じ体制のなかで救急 の専従医の先生が何をしたいかによって, その先生の役割は 決まってくると思います。

00 たとえば 600 床で, 救急車がたくさん来るところに 1 人で行ったら，それはもちろんERのコントローラくらいし かできないと思います。ただ，その医師にどのような資質を 備えていてほしいかということです。

榊原資質というか, どれだけ救急に対して真剣に取り組 んで頂けるかという意欲だと思います。そのなかでサブスペ シャリティがあれば，それをわれわれとしては伸ばしていく 方法を考えると思います。

有賀昭和大学の有賀です。いま司会の方たちが拈聞きに なりたいことを，僕はこういうふうに聞こうと思ったんです。 病院では感染管理のためにインフェクションコントロールの ドクターがいたほうがいいだろう。インフェクジョンコント ロールのドクターは片っ端から感染症の患者を診ているわけ ではありませんが，病院の感染管理に関する全体像について の一定の見識を持って病院医療に寄与している。そういう観 点でいくと, 榊原先生の九条病院, 山木先生のところでは, も し救急医が赴任したとすれば，私はそういう仕事ぶりという のはありうるのではないかと思っています。ひたすら患者と 接することに扔いてのみ, 救急医を求めるということではな いのではないかと思いますが, その辺はいかがお考えでしょ うか。

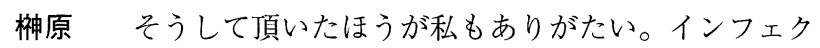
ションコントロールドクターは私と，あと集中治療の専門医 を持っている者とでやっています。

有賀 そういう意味でERとかクリティカルケアといろい ろな話は拀もしろいのですが, 先生のようなところの病院に もし有賀が赴任したとすれば，私は一体何をするのか。そう いう見方でいきますと, 二次救急病院に扔いてもインフェク ションコントロールドクターみたいな形で, その病院の救急
医療全体を俯瞰して，標準からみると何がどういうふうに足 りないとか, この部分は全体からみてもっとやれとか, そう いう形になるのではないか。だから黒川先生が抒感じなっ たようなことを短い期間のうちに僕たちは勉強して, 黒川先 生や僕が実感としてそうやってきて, 10数年か 20 年かかって 到達した部分を, ERとかクリティカルケアとか, こういう学 会のレベルで凝縮的に勉強できた人が, 救急医療の専門医と して先生のように活躍できるのではないかというふうに思い ながら聞いていました。質問の仕方を変えると，こんなふう になるのではないかと思いました。

平出京大の平出ですけれども，いまの有賀先生の意見に まったく賛成です。結局, 救急医の役割というか, ここで論 議しているのは, 最終的には救急医は一つの救急としてのカ ルチャーを育てていくことに尽きると思います。なぜこんな ことを言うかといいますと, 私は京都大学で医学教育をやっ ていますが, 京都大学にはまったく救急のカルチャーがない んです。救急の専従医が 4 人いますが, まったくここの学会 とも孤立しています。来られていたらやばいのですが，おそ らく来られていないのではないか。まず教授会で言ったのは, その 4 人は専門医資格もとれないし, 救急のカルチャーから 隔絶されてしまうわけです。大学としていろいろな関連病院 を含めて，そういうカルチャーをつくっていかないといけな いと言って，ある程度賛同は得たつもりです。そういうこと はよくわかって頂いたと思います。救急というのは全人的と 言うとおかしいですが, 横断的な色彩がありますから, 実際 にクリティカルケアをやるのか, あるいはER的なことをやる のかというところは多様であっても，一つのカルチャーを共 有できる部分はかなりあると思います。

林沖縄県立那覇病院救急の林です。いま平出先生がカ ルチャーという話をされましたが，非常にいい言葉だと思い ました。学会自体でERのことがこれだけ論議されるように なってきたことを非常に嬉しく思っています。ただし救急外 来で初期から診ることにストレスを感じるとか, 救急医がそ れによって疲弊してしまうという意見がありますが，実は診 たことのない患者さんを初めて診て, その人たちに適切な道 を示してあげることに喜びを感じたり，トリアージをして， 緊急度のあるもの，重症度をみつける，宝探しをすることに， わくわくすることを感じる医師もいるわけです。森下先生が 言っていましたが, 救急医の研修としてはまずはERの研修を して, それから集中治療の研修をする。両方ともできること が必要だと僕も思います。ただ将来的にずっと両方やってい けるのかといったら，それはやはり疲れてしまって無理だと 思います。救急の専門という意味ではERをやる人はERをや る人間, 集中治療をやる人間は集中治療をやる人間でいいと 思いますが, ぜひ皆さんの意識, カルチャーとして, ERの新 しい概念を出してほしい。学会としてERの環境を社会に認識 させるという動きを起こして頂ければと思いました。

氏家林先生の発言にもありましたが, 救急というと, 森 下先生が言ったように ERも非常に大事であるという認識は たいぶ出てきました。しかし，クリティカルケアはみんな興 味を持っているというか, 当然やるんだという認識がありま す。いま林先生が扔っしゃったと㧍り，若い先生たちの間に 
「クリティカルケアはいいんだ。ERだけ，つまりアメリカの エマージェンシー・フィジシャンでいくべきなのではないか」 という意見も実はあります。ただ僕自身は救急医としては, クリティカルケアというか, ICUで 2 週間も 3 週間も診る必 要はないと思っています。自分はやってきたけれども，もう いい。それよりも 48 時間とか 72 時間安定化するまでのこと は, 救急医として必要なのではないかと感じています。

八木森下先生が集中治療をというお話は, おそらくわれ われが自分たちのアイデンティティを確立して，モチベー ションを持ち続けるために，ほかの人との違いを持ちたいと いうところがあるのではないかと思います。カルチャーとか, ERの新しい概念をつくる。診たことのない患者さんをちゃん と治療して, そこに喜びに感じる。自分達だけで喜びを感じ て，それを喜びとして持ち続けられる方はいいのですが，そ うではなくて，いまのERシステムでいくと，われわれはずっ とほかの科の先生に頭を下げるばかりの状況になるわけです。 それでリスペクトされるのだったらいいのですが，そのうち に高圧的な態度になってくる場合もままあると思います。そ ういったときに，ではわれわれはほかの先生に対して，何が 専門だというところをみせられるか。それを持ちたいという ことで, 集中治療と言う方もいらっしゃいますし, サブスぺ シャリティだと言われる方もいらっしゃるのではないかと思 います。そのあたりはいかがでしょうか。

○汸の科の先生に頭を下げるということ自体が，い ままでの概念で言っていると思います。もうそうではないと, 僕は思います。一つの分野で確立できると思います。

堀 ER検討委員会の堀です。2つだけお話ししたいと思 います。一つは, いわゆるERモデル型の救急医がいて, その 人のスペシャリティは何かということたと思います。誰もが 認めていることは, ERに 10 人の救急患者さんがビジットし た。病院内のスペシャリスト, あるいはいままでの救急医で もいいのですが, 重症, 軽症をとりまぜて, 本当に初期診療 ができますかという話だと思います。10人に対して標準的な ことがきっちりできるというのが, 一つのスペシャリティで あって，それはジェネラルということが非常に必要になって くるだろうと思います。それが国民からみると一番わかりや すい救急医です。それは救急医学会ないしは救急医のカテゴ リーとしては持ってほしいという基本の考えがあります。そ れから次に, 今日はサブスペシャリティとトレーニングが少 し混乱して使われていた部分があると思います。ER型の救急 医を育てるために， 3 年あるいは 4 年間という時間があると しますと，その半分の期間は他部門へのローテーションが必 須です。そのなかには主要な, 生命に関連するところは全部 のローテーションが必要で, 当然, 集中治療も入ってくると いうことだろうと思います。ERのなかだけで救急医を育てる などということは絶対にありえないと思っています。

入江沖縄県浦添総合病院, 卒後 3 年目の後期研修医, 入 江と申します。若い者の視点からの意見を述べさせて頂きた いと思います。まず私はいま救急総合診療部にいますが，将 来的に救急の専門医をとったのちに整形外科に進もうと思っ ています。その理由は, 整形の専門の先生がいらしたら非常 に失礼なのですが, 整形のお医師さんは人をみていない。骨
と筋肉と腱しかみていない。大学時代に憧れていた講師の先 生にそう言って，殴られそうになりました。(笑)そのせいで 大学を追い出されて, 沖縄まで飛んでいったという話もあり ますが，そういったこともあり，全身管理がある程度できる ようになってから，そこに行きたいという希望があります。 一緒に働いている 5 年目のレジデントは，プライマリができ るようになるために, いま救急総合診療部で働いています。 同じく 5 年目の医師は将来，透析内科をやりたいと言ってい ますが，とりあえずプライマリ，最初のウォークインで入っ てきた患者さんくらいは診られるようになっておくのは医師 として当たり前だろうと思われて, 頑張っています。当院は この 4 月から新型の救命救急センターということですが, はっきり言うと弱小で, 県立那覇病院や中央病院の先生方か ら後乃指を指されているような状態です。若造ばかりで申し 訳ないのですけれども，非常にうまく稼働しているのではな いかと思っています。これは若いからではなく，救急の人間 というのは, 当院では研修委員長がそう言っているからです が, 病院のピースメーカーだと思っています。先ほど黒川先 生のお話にもあったのですが，お互いの相互利益で，「こうい うときは私たちが診ます。いま外科の先生は大変でしょうか ら，私たちが診ます。だから私たちが，ここは外科が必要だ というときにお呼びしますので，ぜひお願いします」といっ た人間関係を，(大病院では大変でしょうが)つくりあげてい くのが救急医ではないかと感じて，いま取り組んでいます。 モチべーションに関しては個々にあると思いますので，それ は個々の先生方の判断に任せればよろしいのではないかと思 います。若造の意見です。

福西 ベルランド総合病院の救急の福西と申します。ベル ランド総合病院は大阪の堺市にあり，500床規模の病院です。 私どものところでは，いま新しい研修医の先生が 2 年目で 移ってこられて, どこでも救急のローテーションが組まれて います。ほかのところでERばかりの研修を受けて，われわれ のところへ来られた先生方は，「ERの先生方は初めだけ診て, あとの治療はしないではないか」ということで，逆に幻滅さ れている方もいらっしゃいます。われわれのところはもちろ ん初療も診ますし，三次まで診ています。逆にERだけという 形で専任されていると，そういうマイナスのことをおっしゃ られた方がいます。そういうご意見は少ないのかどうかと 思って，ご質問させて頂きました。

林 そのERをやっている先生のスタンスがどうかとい うのは一つあります。その先生が嫌々やっているのであれば, そうだと思いますし，そこに喜びをみいだして，それを示す ことができているかというのがあると思います。先ほど浦添 の先生の話を聞いて思い出したのは，ERドクターの役割の一 つとして，医師である限りはすべての医師が本当はできない といけない。でもできない。それを教育する役目として，い ま僕はERを立ち上げていますが，言ってみればERドクター の役目の一つは, 医師としての小学校の先生という感じでも いいかと思っています。

八木 林先生, いま質問された先生は, ERドクターが嫌に なるのではなく, ERドクターということで病院が期待するけ れども, 最初だけ割り振られて, あとは各科の先生が診るの 
で，ERドクターは何だろうということに対する批判があるの ではないかという話です。

林 だからER ドクターは何かというのを学会として バーンと出して, まわりの医師たち, 社会にも示さないとい けないと思います。

八木 ERドクターというのはこういうものですよ，それ以 外は各科でやるべきだということで, ER ドクターというイ メージをしっかり植えてほしいということですか。

\section{林 そうです。}

八木 瀧野先生, どうぞ。

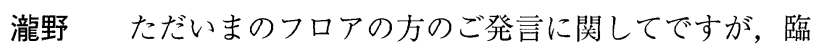
床研修をやっているところで, 研修医の間でERの人気が非常 に高いところと非常に低いところの両方があります。どこが 違うかをみてみると, どこまで治療に踏み込んでいるか。振 り分けだけで終わっているのか。それとも許される範囲とい うか, 常識的な範囲でできる治療をきちんとしているか。そ の辺が大きく違ってくると思います。治療まできちんとする。 もちろんカテや手術はしないのですが, 外来で行う治療まで きちんとするとなると, 生半可な勉強ではできない。一生勉 強するに值する領域ではないかと思います。特にいまここで 指導的なことをされている先生方, 皆さんはある程度の年齢 で，ほかの領域で一人前になられてからERを始められた方が 多い。サブスペシャリティを求める気持ちはよくわかります が，ある意味では腰が引けているというか，どこか逃げ場所 をつくっている。そういう気持ちがしないでもありません。 早川聖隷三方原病院救急部の早川です。患者さんをどう みるかというのは大事ですし，院内の先生方とうまくやるの ももちろん大事かもしれませんが，やはりERは社会との大き な接点です。社会の中で自分のいる場所はどういう役割をす べきか。そういう観点に立ってERあるいは病院を指導してい く, 引っぱっていくという視点が必要なのではないかと思い ます。キーワードとしては「社会の最前線である」, そういっ たカルチャーが必要なのではないかと思って, 発言いたしま した。

太田 湘南鎌倉総合病院の救急外来の太田と申します。先 ほどの大阪の先生への私の考えをお伝えしたいと思います。 ERの医師は時間になったら帰って，あとは患者さんをほった らかしに回して，しんどい思いをするのは自分たちばかりで， お前らは楽をしているという意見ですよね。それは私も非常 に気を遣っています。そう言われないように仕事をしなけれ ばいけない。ただし病院にずっといて，身を粉にして㗢いて いるというふうにもなりたくない。そういう仕事だというふ うにしてはいけないとも思っています。結局, 救急医の役割 は何かというところにもつながるのではないかと思いますが, 最終的に，よい救急医療体制というのは，その地域のなかで 行き場のない患者さんをつくらないことだと思います。たと えば専門医の先生が当直されている病院で, 今日は外科の当 直は脳外の先生だ。足を怪我した人は診ないと言ってしまっ たら，その患者さんはどこに行ったらいいのかわからない状 況が起こりうる。だから患者さんを断ってどこかに行けと 言っていい状況では, ERの医師は必要ないと思います。その 先生たちの希望に応じて患者さんを断ったらいい。先生の病
院がそういったことは許さないで, とりあえずどんな患者さ んでも診る，受け入れるんだ。浦添もそうだと思いますが，そ ういう状況になったときには患者さんがいっぱい来てしまう。 そうすると各専門医が，たとえば頭を打っただけで，いちい ち脳外科が呼ばれていたら大変です。だからその部分をERの 医師が引き受けるという形で役割を分担できて，(浦添の先生 が言われたように便利だと思ってもらえれば, )うまくいくの ではないか。専門医あるいは専門科の当直のドクターの希望 に応じて患者を断るという体制ではない, 地域の患者さんが 行き場所を失わないような体制に病院が参画するのだという トップの気持ちがあれば，逆に専門医の先生は大変になって しまうので，ERの医師は必要だと思われるのではないかと思 います。

八木 いろいろな意見がございましたが，そろそろまとめ ます。杉本先生，何かありますか。

杉本 ERの話もそうですが, 黒川先生の演題を聞いてのこ とですが, 要は日本救急医学会でもクリティカルケアを中心 にやってきたわけです。それとまた一つは，われわれのとこ ろも特殊救急部というので, 彼らは特殊な連中だと言われ続 けてきましたけれども，歴史的に言えば，まず日本の医師た ちは救急医療が大嫌いだった。そういうなかでわれわれが始 めたときに「手伝ってよ」と言っても，「そんなものは知るか」 と言われて，やむをえないから自分たちでやらざるをえな かった。そういう形で一から全部やらなければいけないとい うことで，自己完結型でなくては仕方がなかったのだろうと 思います。しかしそんなことをいつまでもやっていても，黒 川先生がおっしゃるように, 非常に効率の悪い話になってき ます。逆に言えばニッチ産業的に，ほかのところはやらない 高範囲熱傷をやろうではないか, 外傷をやろうではないかと, むしろ自分たちで活動すべき場所を縮めてしまうことがあり ます。時代も変わって, 救急に対するみんなの熱意も変わっ ていった。当初は 1,000 人足らずの学会だったと思いますが, それが変わってきた。私たちは他科の先生方と共同で仕事を することによって，もちろんわれわれが得ることもたくさん ありますし，また他科の先生方もそこから得られるものがた くさんある。それともう一つ，いまERのことを日本救急医学 会として捉えているのは, いままでは重症で死ぬか生きるか, 救命をやるだけで精一杯で, 逆に軽症の救急患者さんのとこ ろまで手が届かなかったというのがあると思います。それが 重症救急患者のある程度のシステムはみえてきた。そうした ら今度は救急医療の潜在的なシステムとして, その前に起 こっていることはもっと多いではないか。救急患者は 2,500 万 くらいだと言いましたが，そのうちの95\%はおそらく初期救 急の対象になる方であると思います。その初期救急医療機関 が対象というか, あるいは外来で帰れる患者さんと言っても いいかもしれませんが，その人たちにとっても実際には結果 として軽症だったというだけです。そのなかには本人にとっ てはわからないだろうし，1〜2\%あるいは 4〜5\%の重症 患者が含まれていることがありますから, やはり日本救急医 学会としてはそのことも含めてやっていかないといけない。 ERという言葉は誤解を招くから, 少し考えたらいいのではな いか。その辺も含めて救急医療システム全体として, どうい 
う形でやっていくか。そのなかでクリティカルケアに比較的 軸足を置く人もいるだろうし，あるいは初期救急も含めたと ころに軸足を置こうという形で，両方あっていいだろうと思 います。

八木 ありがとうございます。いろいろな意見がたくさん 出て，だいたい方向性がみえてきたかと思います。少なくと も救急医としては, 堀先生が㧍っしゃったように, 初期診療 はしっかりちゃんとできるというところをまず押さえて，そ の先どこまで踏み达むかは，それぞれの地域や病院など，ま わりの環境に合わせてもっていくべきかというところもあり ます。ただ何でもかんでもできると便利屋さんになってし まって，そのうちにまた全部押しつけられて，夜間の狩り になってしまうところは避けないといけない。そういう意味 では今度はしっかり救急ができる，初期診療ができるという ことを, まわりの先生たちに認識してもらわないといけない と思います。

氏家 先ほど堀先生と瀧野先生がサブスペシャリティのこ とを㧍っしゃっていましたが, 実は私も瀧野先生もそうです けれども，救急専門医の試験委員を取り組んでいます。この 数年間, 試験問題とか, 救急医は何をどの程度知っておかな いといけないのかということを考えながら取り組んできたの ですが，サブスペシャリティを得るためには，救急専門医と して知っておかないといけないことを，知るような形でのサ ブスペシャリティをぜひ整えて頂きたい。それを飛び越えて サブスペシャリテイを持っているといっても，それはもしか したら救急医ではないのではないかという気がします。です から試験に対しては厳しいという批判もうかがっていますが, やはりクリアできるのが救急医ではないでしょうか。ぜひ幅 広さとある程度の深さをもって，ERももちろんできるけれど も，困ったときにはクリティカルケアにも対応できるという 医師になっていって頂きたいと思います。将来計画委員会で 抒そらく10年計画で救急医の形を今後つくっていくと思いま す。どうもありがとうございました。

平成 17 年 10 月 26 日

\section{SW 3 総㤠}

岡山大学大学院医歯薬学総合研究科救急医学専攻 氏家 良人

日本医科大学武蔵小杉病院, 札幌医科大学附属病院, 亀田総合病院救, 麻生飯塚病院, 手稲渓仁会病院, 京都 九条病院の 6 施設の救急に携わる医師の方々に，それぞ れの施設に打ける救急の現状を踏まえ，“救急医の役割”, “救急医のあるべき姿”について発表して頂いた。6 施設 のうち 5 施設が救命救急センターである。日本医科大学
武蔵小杉病院と札幌医科大学は大学附属病院の救命救急 センター, 亀田総合病院, 麻生飯塚病院, 手稲渓仁会病 院は巨大な民間病院救命救急センターである。そして， 京都九条病院だけが救命救急センターではない民間の救 急医療施設である。ここで，救命救急センターであるか どうかは，これから述べる救急医の役割を考える場合に， 実はあまり関係ない。これらの 6 施設は，救急専従医の 数, 救急医療の形態, 院内における救急医の役割などが 異なっており，ある意味，現在の日本のさまざまな救急 医療体制の代表施設を集めたと考えてもらってよい。各 施設からの報告内容と重複する部分もあるが，まず，そ れぞれの施設の特徵を簡単にまとめ，その後にわが国の “救急医の役割”について記すこととする。

\section{1. 各施設の救急医療の特徵}

\section{1）日本医科大学武蔵小杉病院救命救急センター}

東京郊外の武蔵小杉にあり，2003年10月，救命救急部 として発足し，2006年 4 月に救命救急センターとなって いる。ここの診療形態は，救急部の医師が一次〜三次救 急患者を受け入れ，救急医は三次救急患者には初療から 集中治療まで責任科として担当し，院内各科が担当する 一次, 二次救急患者にも補完的に関与している。また，本 家の日本医科大学付属病院救命救急センターとは異なり, 三次救急医療も自己完結型でなく必要であれば院内専門 科の協力を仰ぐ協力協調路線の運用をしている。専従救 急医の数は明確ではないが，それほど多くないというこ とでおそらく 10 名以下なのであろう。

\section{2）札幌医科大学附属病院救急集中治療部}

札幌市の中心に位置し，1970年代の災害外傷部として の前身があり，1985年に救急集中治療部として新しい組 織を構築し15年以上の実績の後に救命救急センターそし て高度救命救急センターの認可を受けている。発足当初 から, 救急搬送される主に三次救急患者（現在は年間 1200名程度）だけを対象としている。ちなみにウォーク イン患者の救急外来はなく一次患者を診ることはない。 専従救急医は，12名のスタッフ十医員 8 名の 20 名を擁 しており，救急集中治療部入局の救急医と各科からの派 遣専門医がほぼ半々の割合でいる。しかし，各科からの 派遣専門医も数年間という長い期間，救急に専従してい る者もおり，これらの派遣医はすでに救急医の一員とし て考えられる。救急医は初期診断と初期対応，そして，集 中治療に関与しているが，外傷，中毒などはスタッフの 構成から初療から最後まで自己完結できている。しかし， 熱傷の手術は形成外科が担当し, また, 循環器疾患, 大 動脈疾患，脳血管障害などはそれぞれ専門科に引き渡す 
など，専門性を重視して柔軟に対応している。

\section{3）亀田総合病院救命救急科}

亀田総合病院は千葉県房総半島の南端鴨川市に位置し, 周辺に大きな救急病院が無いなかで, 11年前ほどから救 急を開始し, 現在, 年間救急車搬送患者 4,400 例を含め 3 万例を超える一次〜三次の救急患者を受け入れている。 救急医は 3 名の上級医と 6 名のシニアレジデントの 9 名 である。救急医は救急外来で救急車やドクターヘリ搬送 患者の診療, 平日日勤帯のウォークイン外来患者の対応 を行い, さらに, 20〜30名の重症患者, 外傷患者の入院 診療も行っている。しかし, 夜間のウォークイン患者の 診療は各科の当直医に委ねられている。

\section{4) 麻生飯塚病院救急部}

飯塚市は福岡から車で約 40 分ほど離れた筑豊に位置 し, 1,116床を擁する麻生飯塚病院はこの地域唯一の救命 救急センターで, 年間 7 千例を超える患者が救急車搬送 されている。7千例を超える救急搬送患者ということは, 一次から三次までの救急患者が幅広く搬送されていると 思われる。救急専従医はスタッフが 8 名とレジデント 2 名の 10 名で, 一次から三次の救急搬送患者に対する初期 診療, 初期治療を行い, 単独科の疾病や外傷は各専門科 に依頼するER型に近い方式をとっている。しかし, 複合 疾患や複合外傷の対応に関しては, 内科系は総合診療部, 外科系は救急部で対応している。救急部では多発外傷, 重症中毒，外科系疾患の集中治療管理に関与している。

\section{5）手稲溪仁会病院救命救急センター}

手稲渓仁会病院は札幌市の西端に位置し，札幌市西部 や隣接する小樽市以西からの患者搬送が多い。1997年か ら救急医療を積極的に進め, 2005年 4 月から救命救急セ ンターの指定を受けた民間の大きな病院である。一次か ら三次までのあらゆる救急患者を受け入れ, ウォークイ ン患者と救急車搬送患者を合わせて年間 2 万例以上の救 急患者である。救急専従医数は年により若干変動するよ うであるがスタッフ 5〜 7名に若干名の救急研修医がい ると思われる。ウォークイン患者は各科対応になってお り, 救急医は救急搬送患者のみに初期対応し, 基本的に 初期診療とトリアージのER型である。入院となる患者は 各専門科が診ており, 一部, 入院救急患者を救急部で対 応しているようであるが, ICUに入る重症患者は麻酔科 で管理している。この病院の特徵は, ドクターヘリを従 来から独自で運用し，2005年にはドクターヘリの基幹病 院となり, 救急医はへリコプターを駆使した病院前搬送, 治療に関与している。

\section{6）京都九条病院救急科}

京都九条病院は京都南区に位置する 207 床の急性期病
院で，年間 1,800 名ほどの救急車搬送患者がおり，そのう ちの50\%弱が入院している。基本的には二次救急病院と 思われるが，CPA症例も搬入されるようである。20名の 常勤医師がすべて日本救急医学会会員で 4 名の救急専門 医がいるが, 各科専門医であり, 救急部に専従している わけではない。しかし, 全科の医師が救急に関与し, 交 代で当直を担い, 毎朝, 医師全員が当直業務の申し送り 行っている。救急依頼は基本的に断らず，日勤帯などは 院内放送で医師を招集し, 夜間は完全on call体制をとり 救急患者に対応している。

\section{2. わが国の救急病院の診療体制}

厚生労働省が描いたわが国の救急診療体制は, 夜間急 病センターや開業医の輪番による初期救急医療施設, 入 院診療を必要とする二次救急医療施設, そして, 最後の 些としての救命救急センターや大学病院救急部の三次救 急医療施設に機能分化することが進められてきた。

厚生労働省が進める体制は札幌, 東京, 大阪などの大 都会や札幌医大のような大学病院, また一部の地区の救 命救急センターで達成され, そこでは重症であるが数少 ない三次救急患者だけを診療する体制が創られた。しか し, 今回, ワークショップで発表した日本医大武蔵小杉, 麻生飯塚, 龟田総合, 手稲溪仁会などの救命救急セン ターは救命救急センターであっても一次から三次の幅広 い救急患者を受け入れている。実は, このような救命救 急センターの方が一般的であり, 年間数万例の一次から 三次までの救急患者に対応している。しかし，このよう な病院でも, マンパワーの関係からウォークイン患者は 各科当直医が対応し, 救急医は重症患者のみ対応してい ることが多い。

救急病院の診療体制は, 近年, 三次救急医療に特化し ていた病院でも变化が見られる。医師の卒後初期研修制 度が始まり, 救急医療が必修科目となったことがきっか けとなっている。初期研修で求められる救急医療は三次 救急を含めた一次や二次の救急診療全般であり, 多くの 三次救急医療施設でも一次, 二次患者を受け入れ, 研修 医に標準化した教育を行う体制を整えてきている。三次 救急だけを診ている施設は初期研修に適さない病院とい う烙印を研修医から押されかねないのである。

\section{3. 救急医の役割}

上で述べたように，救急医療施設の診療体制の変化が 起こり, 救命救急センターであっても, そこで必要とさ れてきた救急医の役割が変わってきている。

従来, 救急医が専従医として必要とされたのは三次救 


\section{SW3 救急医の役割}

急医療施設であり, 救急医は救急外来およびICUで救命 救急の最後の砦を維持することが主な役割であり, その ような救急医が求められていた。では, 救急医は救命救 急のすべてに対応できるかというと実はそうではない。 ICU管理は生命維持として行う処置はおおよそ決まって いるので, どのような科の患者にも対応が可能である。 しかし, 救急処置室であらゆる外傷, 疾病患者を専門的 に診断, 治療, 手術ができるかというと, そのようなこ とは本来不可能なことである。当然, 各専門科とのコラ ボレーションを必要とするが, 過去においては, 病院に よっては救急医にすべてを預け, 各専門科の協力を得ら れないことがあった。その結果, 救急医だけでとりあえ ず救命救急を完結させなければならない状況に陥った。 一方，これは救急医が何でもできるようになるためには 望まれる状況でもあった。このような環境下で, 救急医 は外科, 整形外科, 脳外科手術, 消化管内視鏡, 人工呼 吸, 血液浄化, IVR, PCPSなどを学ぶ必要があり, それ らの臨床能力を有する者が救急医であった。

現在も, 各専門科の協力が得られないなかで救命救急 を担わざるを得ない，また，そのことを望む三次救急部 門に拈いては, 救急医またはそのグループだけで初療, 手術，ICU管理を行うことになる。しかし，この体制は 救急部門に巨大なマンパワーを必要とする一方, いくら 頑張っても専門科と同等にすべての分野を完遂すること は困難である。自己完結型を追及することは専門科との 軋轁を来し, そして, 最も問題なのは患者の不利益を来 す可能性がある。また, このような三次救急施設だけで 教育された救急医は, CPA, 多発外傷, 呼吸不全, ショッ ク, 重症中毒などに対しては実に力強く頼りになる救命 救急医であるが, ウォークインの軽症患者などは各科が 診るため，からきし不得手な場合が多い。

一方，あらゆる専門科が救急医療に関与できる環境に ある場合は, 救急医は救急外来に来た患者を専門科に良 い状態で引き渡すことが役割となる。おそらく, 北米の ER 体制はこのような環境下でできあがった体制であろ う。ERで働く医師は, 内科系, 外科系を問わず幅広い診 断と初期対応能力を求められるが, 外来対応だけで主治 医となることもなく, 手術や病棟管理, ICU管理の能力 などは必要とされない。このような医師の多くは,わが 国の初期研修医の救急教育において優れた資質を備えて おり，経験すべき幅広い症例に対して標準化した診療，
検査などを教育できる能力を有している。

しかし，あらゆる専門科が24時間救急患者に対応でき る病院は日本では数少ない。ERから患者を渡され軽症, 中等症であれば各科当直医で対応が可能であるが，ICU 管理を必要とする場合, 日常の業務と並行して各科当直 医がICU管理を行うことは難しい。このような病院では, 救急医がICU管理を行うことが期待されるが, 北米型ER 方式で育てられてきた救急医は実は重症患者管理がめっ ぽう弱い。生命のがけっぷちにいる患者に対して, 家族, 各専門科とともに救命救急に関与することは救急医とし て必須なことである。北米では，仕事の評価と収入が一 致することが多いが，最近のNew Engl J Medicineによる と, 各診療科における収入は一番低いのがprimary physicianで ER 医は下から 3 番目である。

私が思う救急医は, 救急外来で一次から三次までの救 急患者に初期対応でき, 研修医を指導でき, 重症患者で あればICU管理を担うことができる医師である。すなわ ち, 従来のように手術などの各科専門的診療技術までは 必要ないが, 軽症患者も含めた幅広い救急患者の初期診 療能力を有し, そして, ICUでの重症患者管理ができる 救急医である。当然のことであるが, 病院内だけでなく, 地域メディカルコントロールに関与し, 病院前診療にお いて救急救命士を指導し, ドクターカー, ドクターヘリ を駆使し救急現場, 災害現場で救命に与ることも救急医 の大きな役割である。

さらに, 救急医は各専門科医師と異なり, 自分の診療 だけでなく病院や地域において横断的役割を担うことが 期待される。感染制御 (ICT), 栄養サポート (NST), 呼 吸サポート (RST), 安全管理, 研修医教育などでは中心 的役割を果たし病院の質の向上に関与し，地域において は, より良い救急医療体制の構貿, 心肺蘇生法の普及, 災 害訓練などで指導的役割を果たすことが期待されている。

最後に, “救急医の役割” はその救急医が置かれた環 境, 状況 (病院の診療体制, マンパワーの大小, 研修病 院か否か，など）で異なってくる。しかし，どこにいよ うとも “救急医”として有すべき能力は保持していなけ ればならない。その意識をすべての救急医が共有し, そ れらの能力を獲得したとき, 救急医は院内で, また, 社 会で専門医として認められていくことであろう。そのた めには, 救急医教育の内容, 方法, 時間などを日本救急 医学会が責任を持って示していくことが重要である。 


\section{SW4 救急医療の採算性}

\section{SW4-1}

\section{典型的 ER の採算性}

沖縄県立中部病院脳神経外科

高岡 諒 林 峰栄 加藤 千紘

松本 廣嗣

\section{はじめに}

沖縄県立中部病院地域救命救急センターは, 典型的な 北米式ERであり, 病院の中心部門として高い activityを 誇っている。筆者は短期間であるが同施設で研修する機 会を得た。近年ER型施設に強い関心が寄せられているこ とから，その採算性について若干の考察を加えて報告す る。

\section{背 景}

沖縄県立中部病院は医療圈人口 40 万人の基幹病院であ り, 病床数 550 , 紹介率 $61 \%$, 平均在院日数 14 日の急性 期, 地域支援病院である。入院患者の約 $55 \%$ は地域救命 救急センター（以下 EC）を経由する。

ECでは, walk-in から救急搬送まで，また傷病の重症 度にかかわらず，全ての救急患者を診療の対象としてい る。ECは初療室, 処置室の他, オーバーナイト観察用の 入院室 $(20$ 床) を擁し，このうち 10 床は救命救急加算が 可能である。ECの診療は屋根瓦式のシステムで行われ る。すなわち, 初期研修医 (総勢68名) がローテーショ ンで初療業務にあたり，各科後期研修医（同 25 名）, EC 専任医 (同4名) 及び各科スタッフ医師の指導を経て, 患 者の治療方針や入院の要否が決定される。入院を要する 患者は各科に引き継がれるため, 専任医や担当研修医は 初療業務に特化している。

\section{目的}

典型的 ER の採算性とその要因について検討する。

\section{方法}

平成 16 年度の患者統計や会計報告に基づき, $\mathrm{EC}$ 受診
患者の分析と EC 単体の原価計算を行った。収入と支出 (原価)は，会計報告に明らかな部分はこれを引用し，他 は案分ないし概算で計上した。研修医，各科医の給与費 については，タイムスタデイが困難であることから，勤 務表とインタビューにより $\mathrm{EC}$ 関連業務時間を推定し概 算した。支出の算出方法を以下に示す。

-給与費：給与明細とEC関連業務時間による案分，概算 $>$ 専任医, 看護師 : 実数

$>$ 初期研修医 (注1) $: 1$ 年次 $=$ 年俸 $\times 7,2$ 年次 $=$ 年俸 $\times$

$$
(5+2 \times 0.5)
$$

$>$ 各科医 (注2) $: 3,4$ 年次 $=$ 年俸 $\times 25 \times 0.2$, スタッフ $=$ $5,10,20$ 年次の年俸 $\times 5 \times 0.2$

$>$ 薬剤師: 処方実績による案分

>技師：検查件数による案分

(注1) 初期研修医は, 勤務表加 1 年次 7 名 /日， 2 年 次 5 名 /日+ 2 名 /半日の専従として概算したが, 実際の業務時間はこれを超過している。

(注2) 各科医は 3,4 年次とスタッフ $(5,10,20$ 年次各々 5 名/日）が業務時間の $1 / 5$ をC 関連業務に充て ているとした。

- 材料費, 注射費 : 実数

・諸経費, 減価償却費：面積による案分

\section{結果}

\section{EC 受診患者の分析}

EC 受診患者数は 38,742 名（受診患者総数の $18 \%$ ）で あった。このうち入院室で 8 時間超の経過観察を行った ケースはEC入院として入院管理料を，またその一部に救 命救急入院料を加算した (上限 10 床)。

- 受診経路：walk-in $82 \%$, 救急搬送 $18 \%$

-受診の時間帯：日勤 34\%, 準夜 45\%, 深夜 21\%

-診療科分類：内科 $36 \%$, 小览科 $30 \%$ ，外科 $14 \%$ ，その 他 $20 \%$

-重症度：帰宅79\%，一般病棟入院18\%，集中治療入院 $3 \%$

- EC 入院：EC 受診患者の $24 \%$

- 救命救急加算：EC 受診患者の $4 \%$

\section{EC 単体の原価計算}

支出は収入の $97.2 \%$ となり，若干の黑字を計上した。収 入については, EC入院の診療単価が高かった。支出の内 訳，給与費の内訳を図 1，2 に示す。 


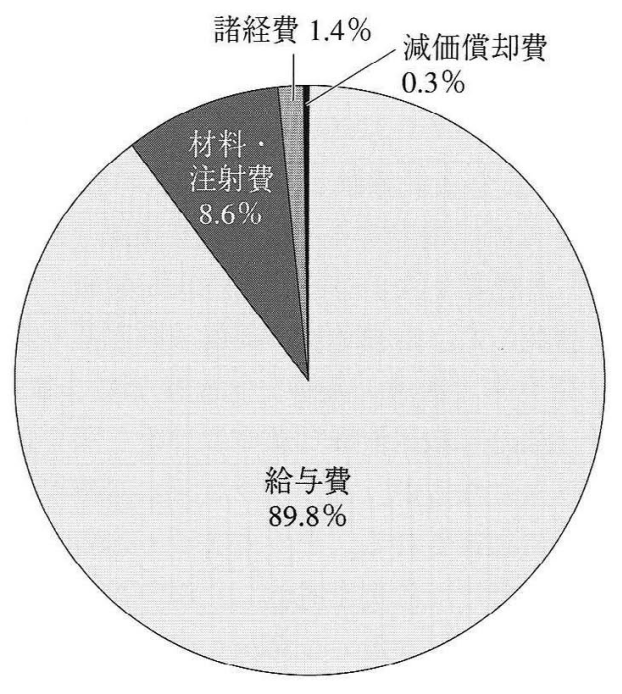

図 1 支出の内訳

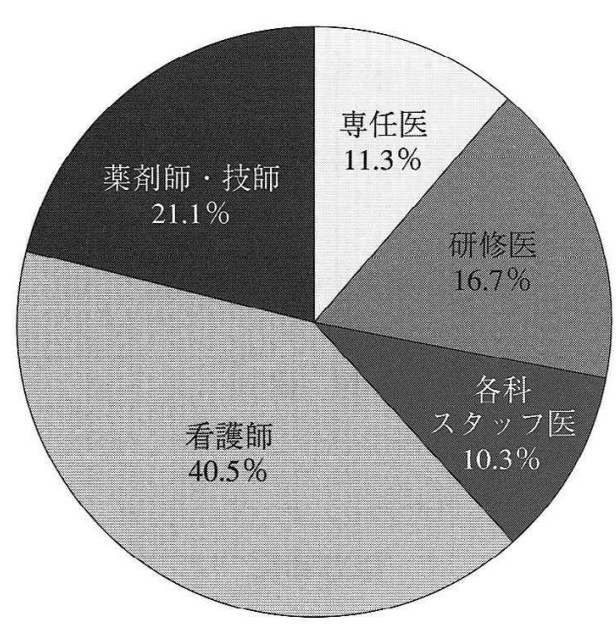

図 2 給与費の内訳
- EC 収入：約 6 億円（病院収入の約 5\%）

- 診療単価：EC外来のみ 11,547円, EC入院 30,974円 (一般外来 8,651 円)

- 支出の内訳：図 1

- 給与費の内訳：図 2

\section{考察}

沖縄県立中部病院は救急医療を根幹としており, 空口 となるECは損益以前に不可欠の部門である。今回の検討 では, EC単体としての直接経済効果は小さいながら, 良 好な採算性が示された。

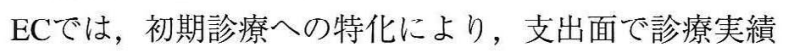
と遇動して増減する材料費・注射費の比率が低いことが 特徵で，「実績を上げれば利益が上がる」，すなわち「患 者数が増えれば増える程，採算性が向上する」パターン である。一方, 患者数が増えれば診療の質やサービスを 維持するため医師の増員が必要となるが, 資質の高い研
修医を充てることにより給与費の高騰を抑制し，採算性 を確保することが可能である。結局のところ, 研修医を 主体とした若手医師を集め，実効的な教育により資質を 高めることが，医療経済の面でも健全な方策であること が示唆される。

な挹，筆者が在籍中に行った研修医達へのアンケート では，「EC業務は厳しい」，「休口がない」「給与が低い」 等の不満はあったものの, 大多数は「EC業務は必要」, 「EC業務は楽しい」と回答しており，診療現場における 魅力的な教育と実践がモチベーションの維持に寄与して いることが考えられた。

\section{まとめ}

典型的ERであるECの採算性は良好であった。その要 因として，1）初期診療への特化と患者数の確保が採算性 を向上させていること，2)研修医の資質が支出の低減に 貢献していること,などが考えられた。 


\section{SW4-2}

\section{2 次救急は本当に赤字なのか？}

一救急の収益評価の指標一

大阪厚生年金病院救急部

木村 眞一

\section{はじめに}

コストがかかる, 診療単価が安い, 平均在院日数を延 長するといった救急医療に対する非難はおそらく当院に 限ったことではないであろう。当院における入院患者数 と入院収益をみた場合, 救急部門が病院全体に占める割 合は各々 $8.7 \%, 7.5 \%$ (平成 16 年度) であった。この数 字を聞けばそうした非難もいっけん不当ともいえない。

2 次救急の入院化率が低いこと, 標榜科として救急の 科目がないこと, 1 人の患者の診療に複数診療科がかか わることが多いことなどから単一の診療科と同列に救急 部門の収支を算出するのは困難である。そこで今回救急 医療の病院全体への経済効果を紹介率や在院日数などか ら明らかにした。

\section{対象と方法}

当院では最近 1 年間（平成 16 年 3 月〜平成 17 年 2 月） に救急車搬送件数はほほ 2 倍に, 時間外患者総数はほほ 1.5 倍に達した。この時期を調查期間とし，医事課資料及 び救急部患者台帳から救急医療の経済効果に関するデー夕

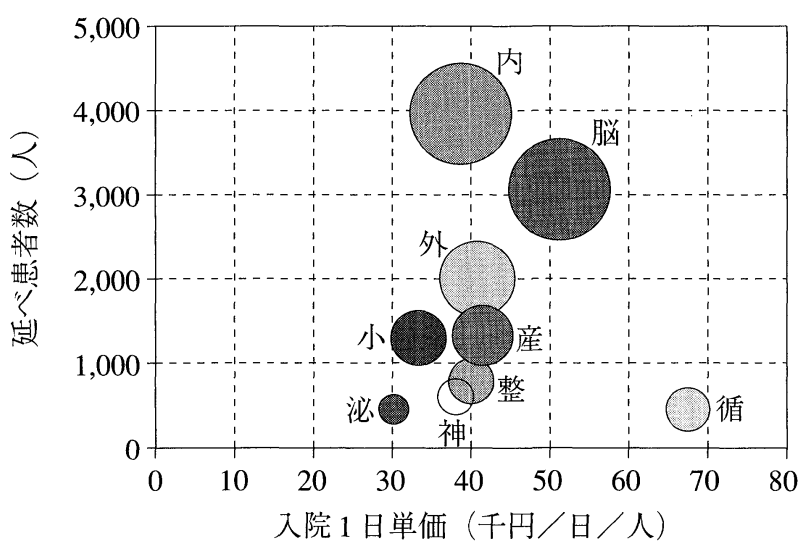

図 1 入院収益（/年）の診療科別特性（H16.3 H17.2） バブルの大きさは入院収益の多寡を示す。
を分析した。

時間外に救急部を経由して当院に入院した症例を救急 入院群とみなし, それ以外の時間外受診患者（帰宅また は他院入院）を外来患者群とした。収入の分析では1）い わゆる売り上げに相当する直接収益の指標（入院収益と 外来収益）と患者 1 人 1 日当たりの入院単価, 延べ入院 患者数を検討した。2)救急部の間接的貢献度の指標とし て, 補正紹介率と救急入院群平均在院日数を算出した。 現行法では救急車搬送件数は紹介状件数と同じ扱いで紹 介率にプラスになるが，そのプラス分は診療事実に関係 なく標榜科に加算される。そこで入院も他科コンサルト なしに救急部だけで診療を完結した例を救急部完結例と 考え, 救急部完結例を除いて算出し直した紹介率を補正 紹介率とした。また救急入院群だけの平均在院日数を算 出し, 病院全体のそれと比較検討した。なお時間外救急 の専従者 (医師 2 , 非常勤看護師 3 , 守衛 2 , 事務当直 1 ) の給与は総額で月 400 万円程度にすぎず，その他の職員 (各科病棟当直, 検査, 放射線科, 薬剂部当直者)の部分 的関与や機器のランニングコスト等は評価が困難である ため，今回は支出については検討していない。

\section{結 果}

1）収益総額は概ね増加傾向で，期間末期にはおよそ月 1 億円に達した。この増加は主として入院収益の増 加に起因して押り，外来：入院の比はおよそ $1: 5$ か ら $1: 8$ へと拡大を示した。

2）入院収益の診療科別特性（延べ入院患者数が月 30 人

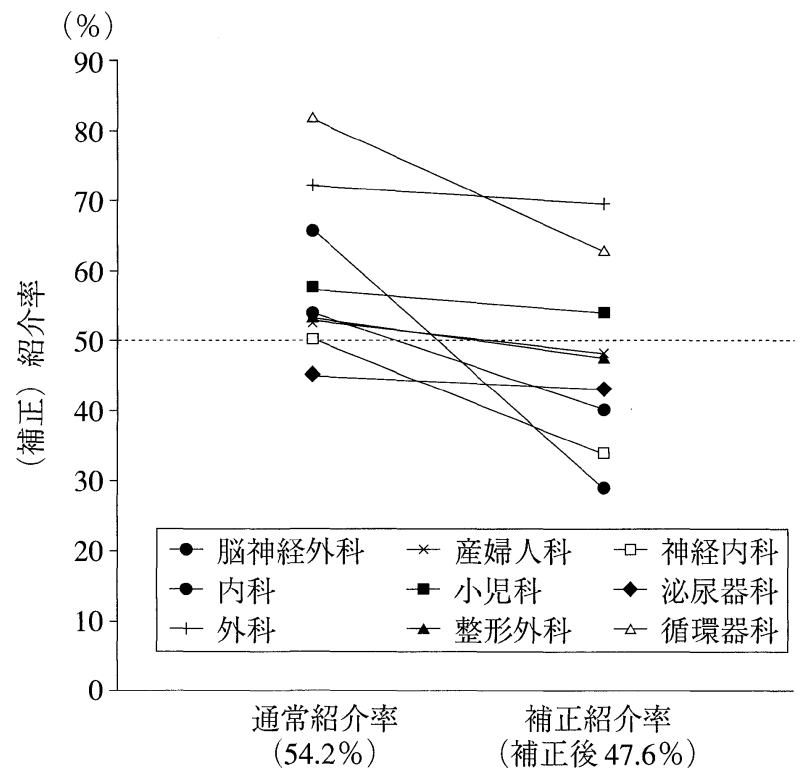

図 2 紹介率の救急への依存度（H17.7） 


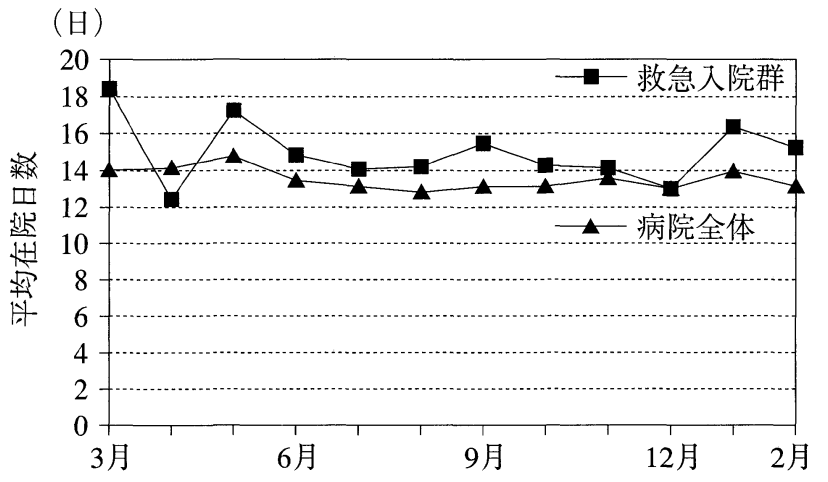

図3平均在院日数に及ぼす救急医療の影響 $(\mathrm{H} 16.3 \sim \mathrm{H} 17.2)$

を超える9科）（図 1）。

脳外科と内科がほほ同額で約半分を占め，同時に 延べ入院患者数も多かった。患者 1 人 1 日当たりの 入院単価は入院収益に大きな影響は与えていなかっ た。

3）紹介率の救急への依存度（上記と同様の 9 科対象, 平成 17 年 7 月）(図 2)。

紹介率は病院全体で $54.2 \%$ あ゙あたが, 補正紹介 率は47.6\%に留まった。診療科別の補正紹介率では, 9 診療科のうち 6 診療科の補正紹介率が $50 \%$ を下 回った。

4）平均在院日数に及ぼす救急の影響（図 3）。

救急入院群の平均在院日数と病院全体のそれとに 大きな差を認めなかった。

\section{考察}

当院での時間外入院収益の増加は, 内科・脳外科患者 の救急車搬送件数の増加に起因していた。この理由は救 急部の専任化, 研修医教育, 脳外科当直の新設, などに
よると考えられるが，その割合は病院全体の入院収益か らみればわずかである。したがって単純な収支から救急 医療の価值を主張しても説得力に欠ける。とりわけ2次 救急病院では時間外の入院化率が低く, 軽症救急患者の 診療や救急車の受け入れといった初期対応・診療に対す る労力が大きい。それにもかかわらずこうした労力に対 する診療報酬はない。つまり, 現行の診療報酬体系のも とで入院収益の多葟だけで, 救急医療の採算性を検討し ても実態を反映していない。

当院での検討結果から分かるように，既存の採算に関 する指標を用いれば，救急医療に立脚している診療科よ りも, 慢性疾患を対象にする専門性の高い診療科の方が 優位に立つことになる。こうした状況で救急医療の病院 に対する貢献度を示すには, 救急医療が病院の施設基準 に貢献していること, 救急医療が慢性疾患を対象とする 診療科に対してもプラスの効果を及ぼしていることを， 数值化して公示する必要がある。今回用いた補正紹介率 や救急入院群平均在院日数なども, こうした指標になり うると考えられた。

支出面の検討は今回行えなかったが, 直接収益や支出 の算出に多大な労力を注ぐよりも間接的な貢献度を明ら かにすることが一般病院の救急の採算性をより適切に表 現できると考えられた。

\section{結語}

1. 救急医療の直接収益の増大は入院患者の絶対数の増 加, つまり入院収益の増加に起因していた。

2. 救急部だけで診療を完結した救急車搬送件数は, 紹 介率 $50 \%$ の底上げに多大な貢献をしている。

3. 救急医療は病院の平均在院日数を延長しなかった。

4. 2 次救急医療は病院の収益向上に寄与する。 


\section{SW4-3}

\section{自治体病院併設型救命救急センター に扣ける救急専従医の採算性}

青梅市立総合病院救命救急センター

川上正人野口 和男田原 憲一 河西 克介 肥留川賢一

\section{背 景}

自治体病院の 7 割は赤字と言われており, その経営改 善が強く求められている。しかしその多くは地域の基幹 あるいは中核病院であるため，たとえ不採算医療であっ ても地域のニーズが高い限り行う必要がある。そのため 不採算医療のひとつに挙げられる救急医療の採算性を高 めることは，その病院経営にとっても有益である。

青梅市立総合病院は総病床数 604 床で東京都の山岳地 帯を含む二次医療圈の中核病院である。その医療圈は東 京都特別 23 区と同心゙広さ（東京都全体の約 1/4）である が, 総人口は約 40 万人と少ない。また，積極的に救急医 療を行う二次病院が少ないうえに, 高齢者施設を多く有 することが特徴である。

この病院に併設された救命救急センターは二次医療圈 で唯一の三次医療機関である。専従医 5 名 (救急医学科) でICU $\cdot \mathrm{CCU} 8$ 床, 一般 22 床を運用し, 一次から三次ま での救急患者の外来診療と入院診療を行っている。勤務 体制は平日・土日祝日を問わず日勤と夜勤の二交代制で, それぞれ救急医学科医師 1 名と臨床研修医 1 2 名で診 療を行っている。救急医学科の外来診療は, 平日日勤帯 は, 救急医学科に直接依頼のあった救急車来院患者に対 応し，それ以外の時間帯は，小児科産婦人科を除く全て の救急外来患者に対応している。入院診療も行い, 多発 外傷, 薬物中毒, 蘇生後脳症, 熱傷などは救急医学科が 入院後も継続して治療にあたっている。手術は各専門科 に依頼し，必要に応じて助手として参加している。また， 時間外入院で専門科による緊急処置を要しない症例は, 救急医学科が継続して入院業務を行い, 翌日あるいは休 日明けに該当科に引き継いでいる。

\section{目的}

当科のような総合病院に併設した救命救急センターで,
専従医により独立型でも ER 専従型でもない形態で運用 されている救急部門の採算性を検討するため, 平成16年 度の救急医学科の患者数, 紹介率と医業収益を病院全体 のそれらと比較した。

\section{結 果}

平成16年度は診療患者数 11,899 人, うち救急車来院数 3,741 人（三次対応 832 人）であった。 1,834 人が当日救 急医学科で入院となり，1,438人が入院後他科に引き継い たため, 救急医学科の入院収益となったのは残りの 396 人であった。

初診料を算定した救急医学科患者数は 5,407 人で, 紹介 率は $45.8 \%$, 平均在院日数は3.4日であった。病院全体で は紹介率 $35.7 \%$ ，平均在院日数 14 日であった。

救急医学科の医業収益は外来単価が 14,340 円，入院単 価が7,4381 円であった。病院全体では外来単価が 1,3417 円，入院単価が 4,3597円であった。

\section{考察}

当院のように医療圈内に診療所や病院が少ないところ では，紹介患者が限られ初診患者の多くが直接来院する。 そのため紹介率を高めるのは難しい。とくに救急外来は 初診患者が占める割合が高く，直接来院患者は救急車来 院患者より数倍多いため, 紹介率は低下する。救急医学 科の紹介率は $45.8 \%$ と低かったが, 病院全体としては紹 介率を上げるよう働いていた。しかし今後時間外受診患 者が増加すると紹介率がさらに低下し，その結果紹介率 加算が算定できなくなり病院として多大な減収となる可 能性がある。

救急医学科の外来単価は病院全体と比して高かった。 その理由として, 救急外来では血液検査や画像診断の頻 度が高いことと時間外診療は診療報酬で加算される項目 が多いことが挙げられる。加えて, 直接来院患者は入院 率が低いため，その大部分が診療した救急医学科の収益 となる。平成15年度以後，臨床研修医とともに救急車来 院患者だけでなく直接来院患者も積極的に受け入れる体 制にしてからは，その患者数の増加とともに収益も著明 に増加した（図 1)。

入院単価も病院全体に比して高かったが，平成13年度 以後は収益にあまり変化はなかった（図 1 )。入院単価が 高くなる要因として高額な救命救急入院料が挙げられる。 救急医学科は延べ 1,679 日救命センターで入院診療を 行ったが，そのうち救命救急入院料を算定したのは $1 / 3 の$ 574 日だけだった。これは救急医学科が担当する患者群 は救命救急入院料を算定できる重症患者の比率が低い, 


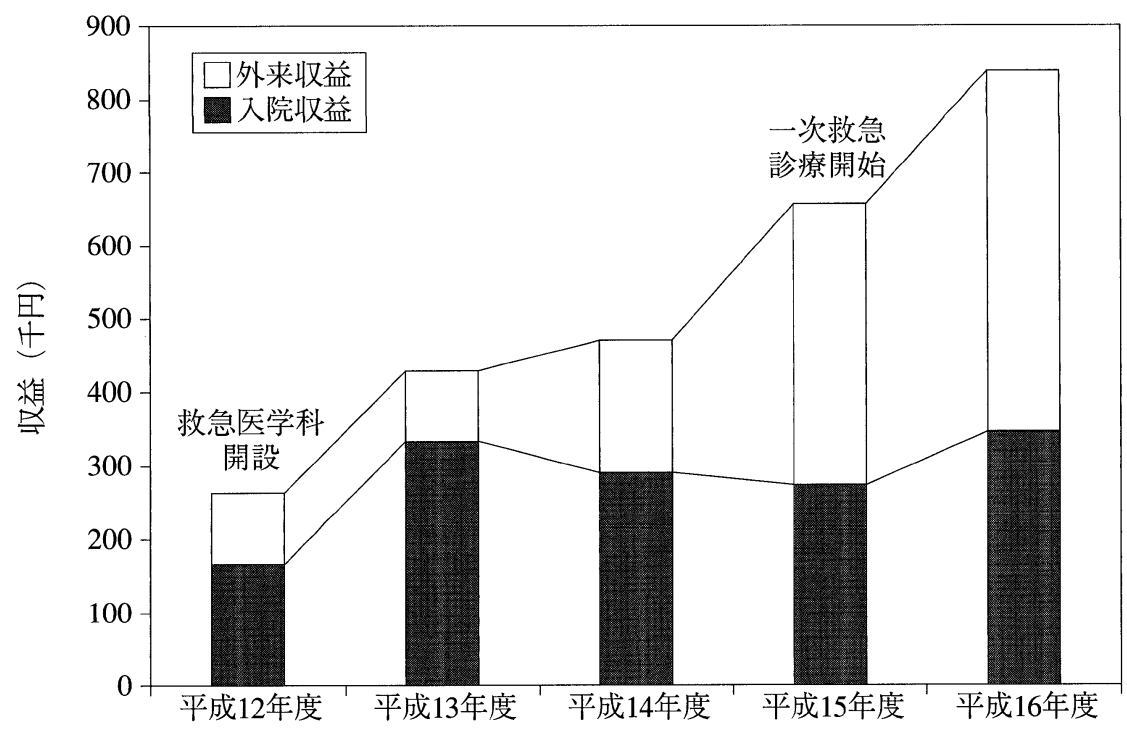

図 1 年度別一日あたりの収益（救急医学科）

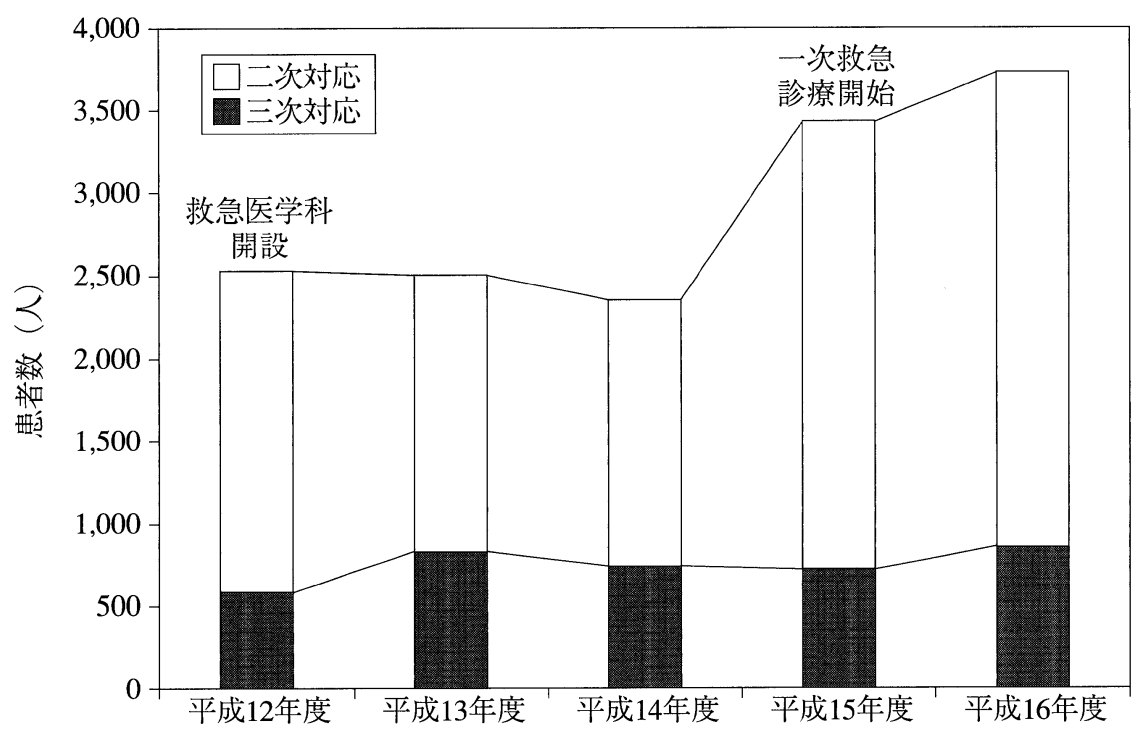

図 2 年度別救急車来院患者数

来院時重症であっても短期間に回復する症例が多い，あ るいは症例数が少ないことによると考える。救命救急セ ンターとして積極的に三次対応患者を受け入れてきたが (平成 16 年度東京消防庁からの三次対応患者の受け入れ 率は95\%)，その患者数は微増に止まっていた(図2)。と くに平成 15 年度以後救急車受け入れ台数は増加したが, 二次対応救急搬送が増えただけであった。救命救急入院 料を加算できる重症患者数は変化しなかったため, 入院 収益は外来収益ほど増加しなかった。

救急医学科の診療には収益として加算されないものが
ある。救急医学科が初療し入院後に他科診療となった症 例は，外来分を含めて全て該当科の収益となる。平成 16 年度はそのような症例で延べ 1,767 日の救命救急入院料 が算定された。

自治体病院の使命として重症度を問わず可能な限り救 急患者を受け入れている病院は多い。その救急外来を当 センターのように少人数で運営する救急専従医の採算性 は高いと考える。そしてその収入源として重症患者の入 院収益だけでなく，数が多く診療単価が高い一次対応患 者の外来収益も重要である。 


\section{後 記}

ワークショップの質疑で，診療報酬の改訂内容により 救急部門の採算性は大きく影響を受けることを指摘した。 平成18年度の改訂により, 救命救急入院料や救急医療管
理加算が増額となるなど，救急医療は優遇された。とく に紹介率の廃止により，救急医療を行えば行うほど初診 患者が増え紹介率が減り，結果として多額の減収となっ てしまう矛盾は解消された。

\section{SW4-4}

\section{自己完結型運営による 救命救急センターの収益と採算性}

\author{
川口市立医療センター救命救急センター \\ 小関 一英
}

\section{はじめに}

平成 6 年 5 月開設以来, 当院救命救急センターは, 外 科·脳神経外科·整形外科のそれぞれの認定医や専門医資 格を持つ救急認定医（専門医）を中心に自己完結的に診 療が行われてきた。年間約 1800 名を収容するが，そのう ちCPAOA 及びICU 入室を要した重症患者は約 $50 \%$, 一 般病棟への入院は約 $30 \%$, 診療後帰宅し外来扱いのもの 約 $20 \%$ ，開設から平成16年度までこれらの割合はほと んど変わらなかった。重症外傷, 急性腹症, 脳血管障害 などに対する緊急手術を含めて, 専用のICU（平成16年 4 月より 6 床から 8 床に増床) と後方病棟（同， 21 床か ら30床に増床）を持ち運営されている。その収益は院内 診療報酬請求などの処理上,「外科救急」として他の臨床 標榜科とは区別して計算がなされてきた。たたし，国及 び県への届け出では循環器科が運営する CCU/ICU（各 4 床）も救命救急センターに含まれるが，本稿では国及び 県への運営状況報告書に打ける収支状況部分以外は, 先 に述べた救急医が運営する狭義の救命救急センターの収 益を中心に述べる。

\section{方法}

(1) 平成 $11 \sim 16$ 年度の 6 年間の救命救急センター収益 実績の年次推移を示し, 入室患者数と収益との関連 について検討した。ICU増床とともに新しい施設基 準による診療報酬が導入された平成16年度の収益に
与える影響をみた。

(2) 平成 16 年度について，患者ごとに入院収益額を 50 万 円未満〜 500 万円以上の 11 段階に分類し，高額と言 われる救命救急センターの入院費の患者構成比を調 ベた。

（3）損益収支分析は，厚生労働省による救命救急セン ター充実度調査の際の報告書に基づいた。平成12年 度〜 14 年度, 及び平成 16 年（暦年）の 4 年間分の 平均で算出した。報告書はCCU/ICUの収支が含まれ るため，収支額が約 $30 \%$ 上乗せされているとみなさ れる。医業費用については，厳密な部門別原価計算 が不可能なため, 材料費と経費は当院の配賦基準に 基づき案分とした。給与費（救命救急センター専従 医師及び看護師等の実給与), 材料費 (総支出から三 次救急収入額による案分計算), 経費 (賃金等は患者 数・手術件数割り，光熱費等は部門面積数割り）及 びその他の 4 種の費用の合計で行った。 記述に際しては百万円未満を切り捨てた。

\section{結 果}

\section{1. 救命救急センターの年間医業収益}

平成 11 年度から平成 16 年度の 6 年間の年間入院収益 は, 7 億 4,700 万円 9 億 2,600 万円（平均 8 億 6,600 万 円), 外来収益は 3,100 万円 5,900 万円 (平均 4,600 万円) であった。すなわち，収益の約 $95 \%$ は入院収益によるも ので, 両者の合計は, 7 億 8,000 10億 3,200 万円 (平均 9 億 1,200 万円）であった（図 1)。

この間，年間延べ患者数の平均は 15,900 名，1 日平均 在院患者数46名であった。専従医師数は 7〜9名であっ たが，医師 1 人当たりに換算した年間収益は 9,800 万円 $\sim 1$ 億 3,400 万円 / 人 (平均医師数 7.8 人, 平均収益 1 億 1,700 万円/人) となった。救命救急センターは病院全体 での入院収益の $11.3 \%$ （6 年間平均）を占め, 内科 $(20$ $\%) \cdot$ 産婦人科 $(13 \%) \cdot$ 外科 $(12 \%)$ に次ぐ構成比を維 持した。 
SW4 救急医療の採算性

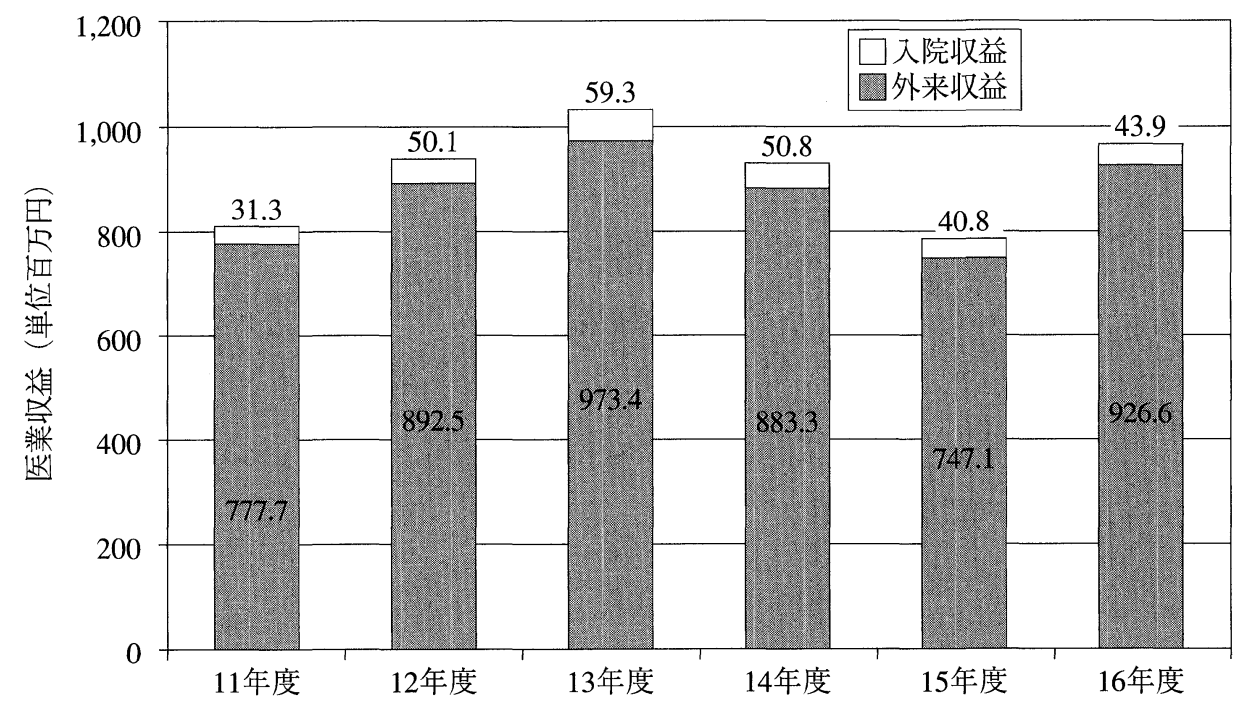

図 1 最近 6 年間における救命救急センターの医業収益 15 年度の収益の落ち込みは, 3 か月間の救命救急センター増床拡張工事 (6 床 $\Rightarrow 8$ 床）による患者収容の減少による。当救命救急センターの医業収益の $95 \%$ は入院収益である。

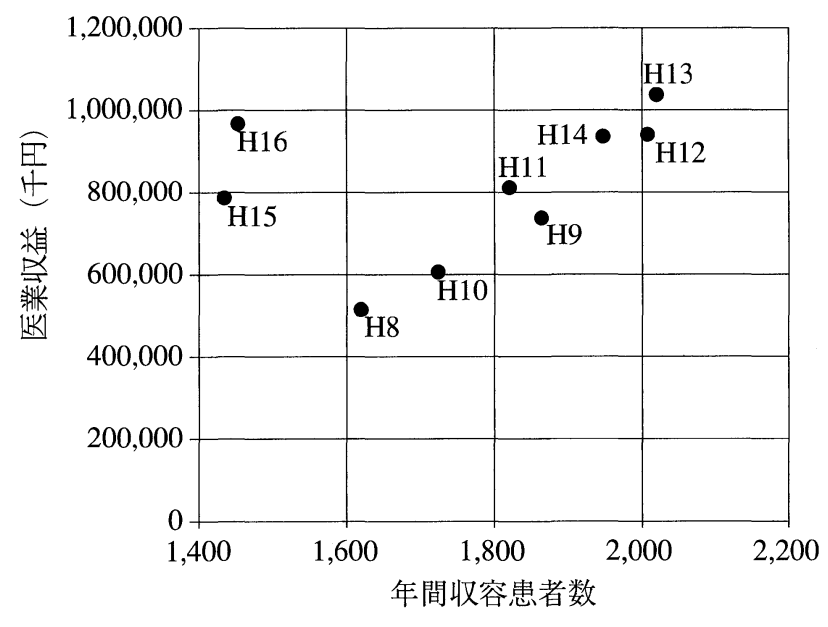

図 2 救命救急センターの年間収容患者数と医業収益の関係 図中の記号は平成 $(\mathrm{H})$ 年度

平成 8 年 14年度までの医業収益は, 年間収容患者数と極め てよく相関したが, 救命救急センター拡張工事のため 3 か月 間ほぼ閉鎖した平成15年度と, 増床と診療報酬上の格上げが 行われた平成 16 年度は, 相関が崩れた。

\section{2. 収容患者数と入院収益の関係}

平成14年度までの入院収益は収容患者数とょく相関し たが $(\mathrm{r}=0.97)$, 拡張工事のため救命救急センター ICU が3か月間閉鎖された平成15年度は収容患者数の減少が 収益の低下となって表れた（図2)。一方, ICUと後方病 床の増床と, 診療報酬上の救命救急入院料のランク上げ $(9,190$ 点 $\rightarrow 10,590$ 点) が行われた平成 16 年度は, 収容患
者が以前に較べ約 400 名減少したにもかかわらず入院収 益は, 前年度比で 24\%（1 億 8000 万円）増加した。

\section{3. 入院収益額区分による患者構成比}

1 人当たりの収益 100 万円未満が入室患者の約 $82.2 \%$ を占め，全収益の約 $42 \%$ 占めた（図3）。逆に，100万 円以上の医療費がかかった患者の構成比は入室患者の約 $17.8 \%$ に過ざないが，全収益の半分以上（58\%）はこれ ら高額医療患者から得られたことになる。

\section{4. 救命救急センター損益収支分析 (厚生労働省充実 段階調査報告書より)}

収支分析では, CCU/ICUを含む救命救急センターの年 間収益額は 12 億 2,200 万円 14 億 800 万円 (平均 13 億 6,400 百万円，うち入院収益が 13 億 2,200 万円を占める) であり，これに対して，歳出額 (いずれも平均額で示す) である給与費（6億 9,200 万円）・材料費（4 億 4,900 万 円) - 経費 ( 1 億 3,800 万円) - その他 $(4,300$ 万円）の合 計は, 13 億 2,400 万円であり, 平均 4,000 万円の黒字を計 上した (図4)。なお, 同期間の平均年間延べ入院患者数 は 17,355 人，1 日平均入院患者数 47.5 人であった。

\section{考察}

多くの一般診療科医師が救急医療に背を向けているの は全国的な傾向である。救急医療に専従する医師達（救 急医）にとっては，好むと好まざるとにかかわらずさま 
シリーズ・ワークショップ

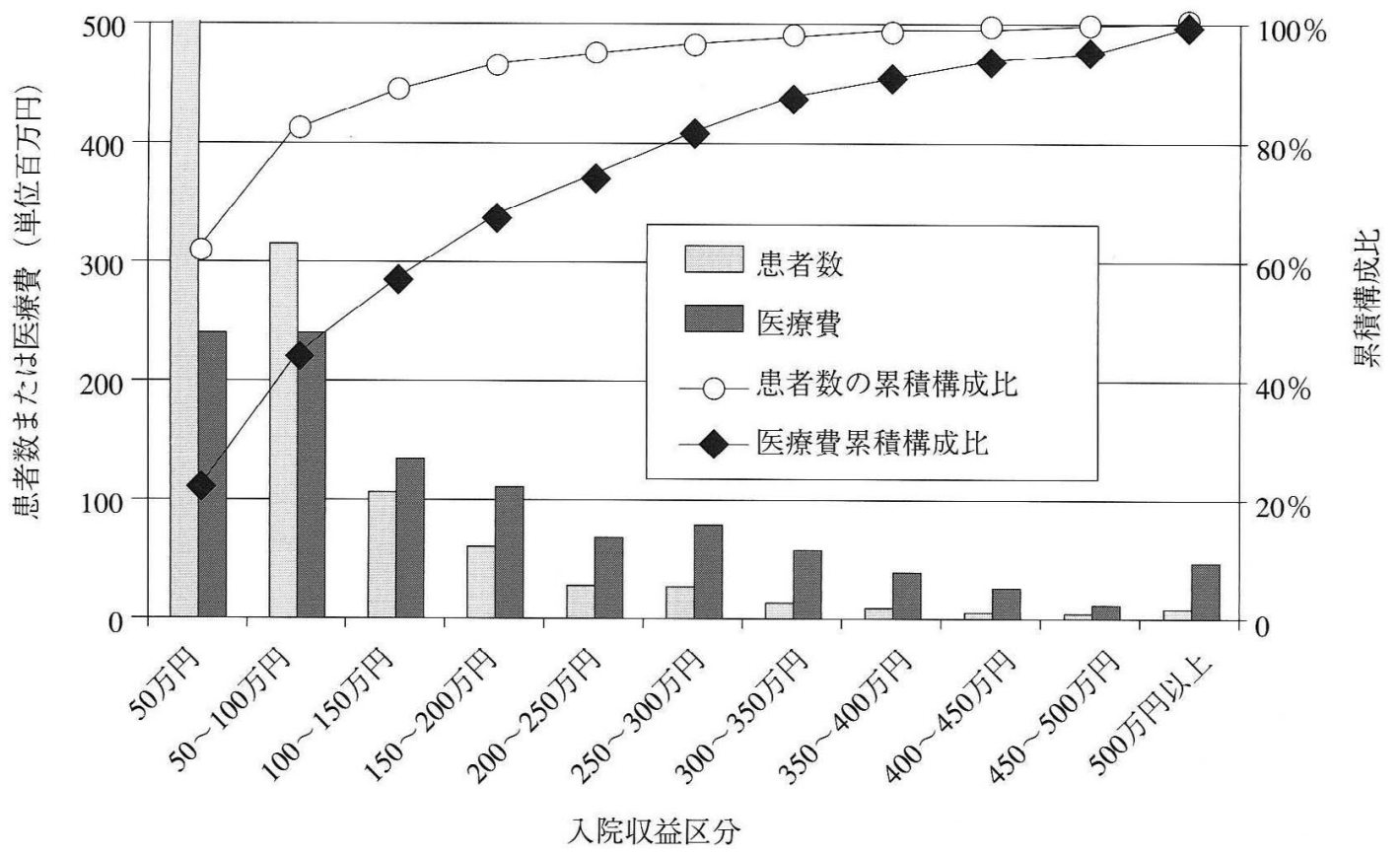

図3 入院収益額区分の構成比とその患者数 (平成 16 年度, 全入院患者 1570 名を対象)

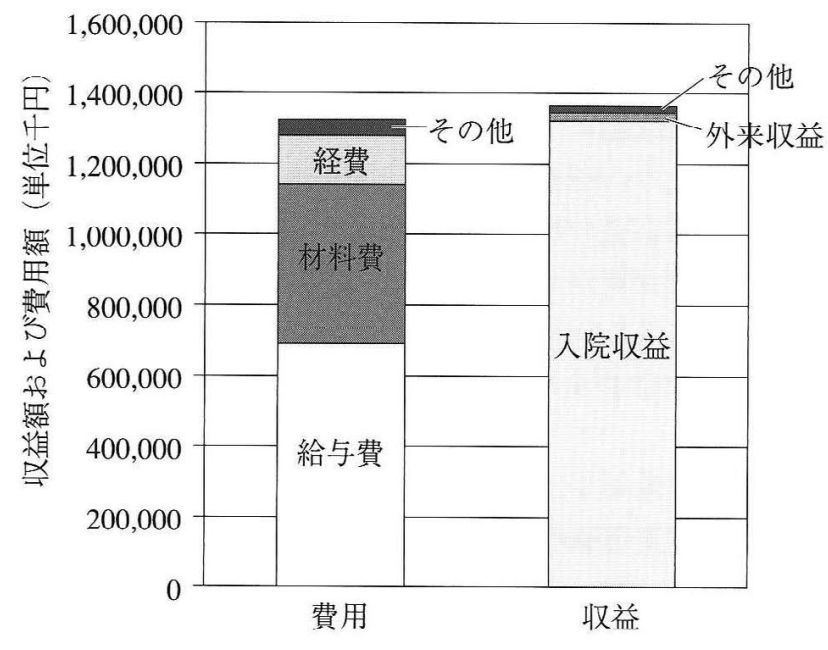

図 4 救命救急センターの損益的収支分析

厚生労働省「救命救急センター充実度調査報告書」に打け る収支決算資料に基づき，平成 $12 \sim 16$ 年の平均額で表示 した。ただし，平成 $12 \sim 14$ 年は年度決算，平成 16 年は暦 年決算，平成 15 年度は資料不足のため計算に入れず。

ざまな体制の中で，救急医療を実践する必要がある。所 属する医療施設の救急医療に対する取り組み方や，他科 の医師の協力次第で, 独自の方法で診療上の立場を確立 しなければならない。厚生労働省が指定する第三次救急 医療施設として地域医療に貢献するために，われわれは 開設以来，他科に頼らぬ『自己完結型』の医療を実践し，
消防機関とコメディカルの協力を得て独自に救命救急セ ンター運営の道を切り開いてきた。その成果は医業経営 上からも評価しうることを証明する必要がある。

本報告では，救急専従医（7〜9名）により運営され ている当院救命救急センターの, 最近 6 年間 (平成 11 年 〜16年度)の主に医業収益からみた採算性について検討 した。救命救急センターの増改築工事のため 3 か月間 ICU が使用不能となった平成 15 年度は, 救命救急セン ターとして, 前年度比 1 億 3,600万円の減収となったた けでなく, 病院全体としての収入は前年度比で 3 億 6,600 万円の減収を来した。この理由を全て救命救急センター の減収に帰結することはできないが，救命救急センター の診療活動の停滞が，院内全体の収益に影響を与えたこ とは否めない。ちなみに，増改築後の救命救急センター はCCU/ICUを除いても 17 年度決算で 12 億円に昇る収入 を上げて㧍り，病院事業へ好影響を与えている。

経営戦略上, 機会/脅威分析に抢ける外部環境の視点か らみると, 救急医療は診療報酬や, 救命救急センター運 営補助金制度，臨床研修医制度，消防機関からの依存性 などさまざまな追い風のもとにある。ところが，内部環 境の強み/弱み分析からすると, 救急専門医を除く一般診 療科医師の救急医療への無関心や逃避的態度により救急 医療を「強み」として認識されているとは言い難い。救 急医療を医業戦略として位置づけると，医師主体の医療 ではなく，患者中心の医療の実践力がその採算性を得る 
に必要不可欠である。

当院救命救急センターの運営戦略と実績から, 救急専 門医による自己完結的診療を堅持し, 診療のアクティビ ティを高めることと, 第三次救急患者 (ICU入室が必要)
を収容患者数の $50 \%$ 以上（年間約 900 名前後）に維持で きれば十分な採算性が得られるだけでなく, 医業経営上 の貢献度は極めて高いと考えられる。

\section{独立型救命救急センターの 運営実績からみた経営分析}

\author{
大阪府三島救命救急センター
}

森田 大

\section{はじめに}

重症患者の救急医療の採算性を，費用採算をもってあ るのかと問われれば，答えは否である。度重なる診療報 酬改訂の誘導によって, 病院は機能別に分化されたが, 急性期重症患者の受け入れが確保されたかという検証は なされていない。最近になって, 急性期医療の置かれて いる現実が認識されつつあるとしても，やはり補助金な くしては, 重症救急医療は現行の診療報酬では賄えない 現実がある。救命率の向上(死亡率の低下), 救える命を 救う医療を, 患者受け入れによる紹介率の向上, 他科へ の寄与や診療付加価値的意味合いとして捉え，採算をみ るのみでは，真の経済投入に見合った救急医療の分析と はいえない。あるいは，後送の診療科が昼夜を分かたず かつ症例を選別することなく, ERと連続して機能するシ ステムを担保できなければ，その付加価值も生きてはこ ないだろう。そもそも救急医療の意義を定量化し, 採算 性を経済的数值で表そうとしても, 病院全体の収益の中 に隠れてしまうか, 質を数值として評価しにくいために, 困難と言わざるを得ない。当センターは, 自己完結型の 救命救急ユニットとして, 病院そのものが救急医療経済 正味であり，医療全体のなかでの救急部分をどう評価す るのか, ひとつの医療経済モデルとなり得ると考える。 高齢化社会が進む中で，GDPに占める医療費の割合が高 い伸び率を示し, 医療費の削減が叫ばれる中, 病院も事 業体であり，赤字にならないよう採算性をにらみながら 経営すべきものとしても, 救急医療は誰かがやらねばな
らないのである。当センターの，患者の立場に立った医 療経済の改善努力と, 職員の不断の取り組みを紹介し, 救急医療の “採算性”について問題提起したい。

\section{累積赤字解消への努力}

当センターは大阪府の北部, 70 万人の三島医療圈にあ る高槻市に立地し，救急医療に特化した第三セクター方 式の財団法人立として発足した。年間総運営費は 22 億 円, 医業収入 16 億円, 運営補助金約 5 億円, その補助金 の内訳は, 国庫補助を含む大阪府からの補助が 1 億 3 千 万円, 地元高槻市と島本町による補助金が約 3 億 8 千万 円である。職員数 148 名, 研修医を含む医師数 27 名, 入 院患者約 1,000 名, 日当点は 11,573 点, 平均在院日数 9.3 日，充床率 $86 \%$ である (2004年度)。開設時の建設費用， 設備費，運営費などの資金約 20 億円を全て借金で賄い, 上記の定額補助金のみで独立採算運営し, 二十年が経過 した。ゼロからの出発どころかマイナスからの出発で あった。最大時は建物償還に加えて, 約 7 億の運営累積 赤字を抱え，センターは存続か閉鎖かの岐路に立たされ た。今から 10 年前, ちょうど発足後 10 年目のことであっ た。財政立て直しのために，まず支出の見直しを図るべ く, 当たり前のごとく実施していた中心静脈栄養, 抗生 剤や血液製剂のふんだんな使用等の見直しを行った。集 中治療では常識として罷り通っていた高価な薬剤に対し て治療効果は上がっているか, 合併症の発生要因は何か など検証するなかで, 中心静脈栄養から早期経腸栄養へ, 抗生剂使用の抑制など治療方針を転換した。患者の自然 治癒力を損なわない治療方針は, 二次的感染・敗血症 · 多藏器障害の防止, 死亡率の改善をもたらしただけでな く，同時に大幅な薬剤費の削減につながったのである。 当センターの経済的推移を図1に示す。医業収入は受け 入れ患者数の増減とほぼ連動しているが, 第三次医療法 改正を経て, 診療報酬は約 7 \%アップしたことが大きな 追い風となり，医業収入を右肩上がりに押し上げた。 1995年に行った治療方針変更による薬剤費の削減効果に よって，それまでじわじわと上がっていた薬訪費がその 時点から横這いで続いたと仮定しても，その後の10年間 で約 17 億円の薬剤費を削減したことになる。 
シリーズ・ワークショップ

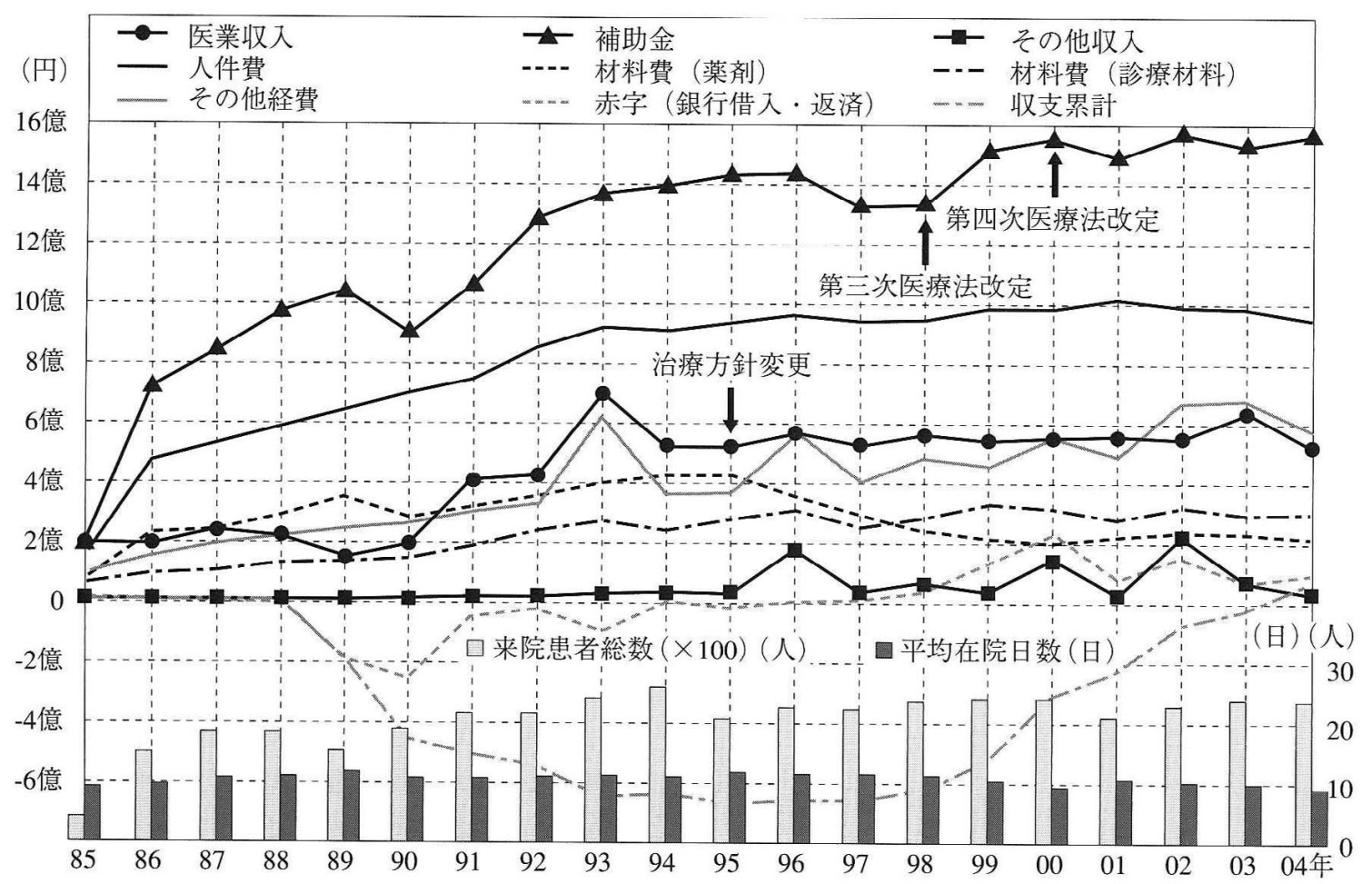

図 1 大阪府三島救命救急センター収支推移表

$\square$ 総支出額（ $\square$ 給与費 $\square$ 材料費 $\square$ 経費 $\square$ その他）

総収入額（ $\square$ 診療収入費 $+\square$ 国庫補助受入額）

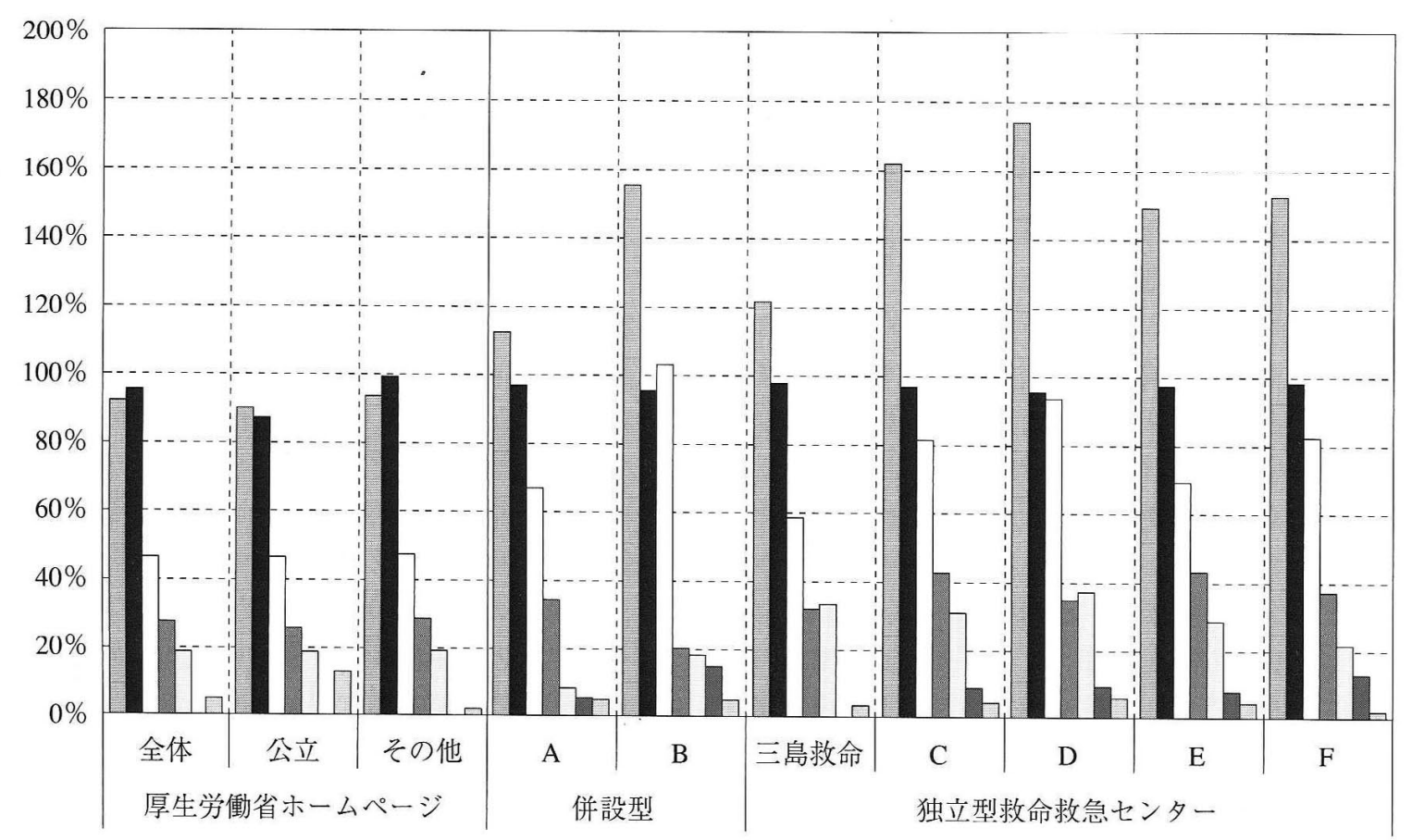

図 2 総収入に対する総支出・各支出内訳の割合（総収入額を $100 \%$ とする） 
同時に各科専門医資格を持つ救急医みずから，積極的 に広域で重症患者を受け入れる努力を惜しまなかったこ との相乗効果により，収入を確保してきた。もちろん受 け入れを断われば，亡くなる患者が出るであろうという 認識もあったが，「直送患者の受け入れは断わらない」, また先に述べた「患者の治癒力を損なわない治療に徹す る」という精神は，現在センターの診療理念となってい る。そして, 不断の取り組みで設立 20 年の今期, 累積赤 字を解消し建物の償還も終わり，単年度黒字を計上する ところまでに至った。

\section{国民の安心・安全を担保する救急医療の収支}

当センターは, 補助金の支えにより運営できていると いう指摘は否定しない。5つの独立型救命救急センター 及び 2 つ併設型救命救急センター（救命部門のうちみ えない収支内訳については案分により算出，補助金は国 庫補助のみとし，赤字補填分は抜いたデー夕を作成依頼 した）と，急性期加算の病院（平成 17 年 1 月 26 日, 中 央社会保険医療協議会第14回医療経済実態調查報告を利 用し，「その他」は，当センターと似た収支形態をとる病 院とした）との収入に対する支出割合を比較したのが図 2 である。独立型, 併設型ともに救命救急センターの経
営状況は赤字であった。総収入に対する給与費の割合は, 一般に企業が存続できるといわれている50～55\%を大 きく超えているのが分かる。ところが, 独立型救命救急 センターの総支出に対する各支出内訳の割合は, いずれ も急性期加算病院とほぼ同率であった。つまりマンパ ワーを投入しながら収支に見合った医療費削減努力をし ても, 重症患者急性期医療への診療報酬は低いので, 赤 字回避は困難ということである。先に述べたように, 独 立型救命救急センターの収支状況は, 急性期重症患者の 医療を評価するための指標になり得ると考える。日本救 急医学会は, この点を鑑み, 安心·安全の救急医療を確 保するために，運営補助金の投入を国に提言すべきであ る。

\section{まとめ}

職員の努力により収支改善が得られたが, 運営補助金 による埋め合わせがあってのことである。赤字補填しな い条件で, 最低限の補助を社会基盤整備の一環として保 証しない限り救急医療は存続しない。

\section{SW4-6}

\section{国立大学病院管理会計システムを用いた 救急医療部門の収支分析の試み}

宮崎大学救急医学教室

岡本 健 松島 俊介 寺井 親則

救急医療は一般的に不採算医療の代表とみなされてい るが，地域の中核となる救急医療施設が質の高い医療を 提供しつつ存続するには，健全で安定した経営基盤を確 立することが最重要課題である。そのためには, 救急医 療部門の損益構造を把握し, 経営上の問題点や改善点を 見出すことが必要不可欠となる。

今回, 宮崎大学病院救急部を対象に「国立大学病院管 理会計システム (HOMAS)」による診療科別原価計算を 試み, 救急医療の採算性を評価するッールとしての有用
性を検討した。

\section{方法}

\section{HOMAS の概要}

HOMASは国立大学病院が平成 16 年の法人化に備えて 開発した管理会計システムであり, 平成16年に第一期開 発版（診療科別・部門別原価計算・経営処理等）が完成 し全国導入されている。HOMAS では, 管理会計は一元 的に管理され，長期間の生データを共通のフィルター, 独自のフィルターで分析可能である。中間データを分析 可能な形式で保持できるためデータの追跡性が高い。ま た, 沉用性重視の設計により, 多種多様な運営形態を取 る全国の国立大学病院に対応し, 他施設間のデータ比較 も可能である。

\section{2. 宮崎大学救急部の背景}

宮崎大学病院は宮崎市郊外に位置する18診療科 616 床 の特定機能病院である。救急部の診療対象は原則的には 二次·三次の救急搬送患者であるが, 依頼のあった時間 外一次救急患者の診察も行う。専属医 3 名と研修医 1-2 
医業収益

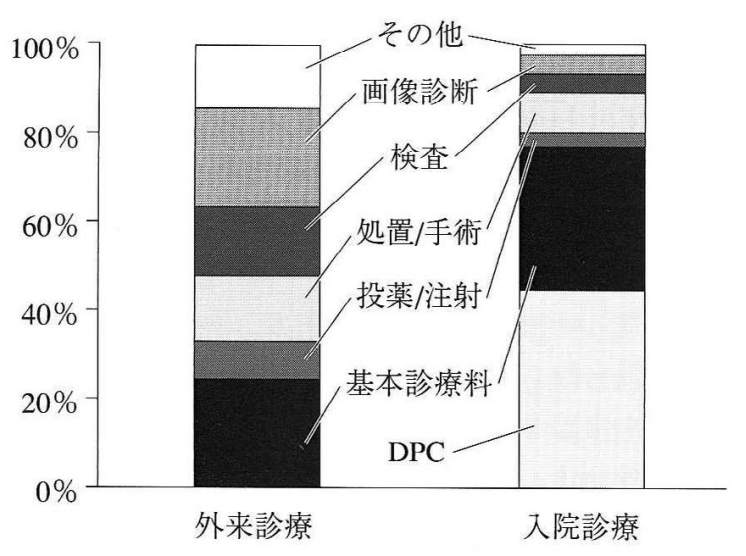

診療経費

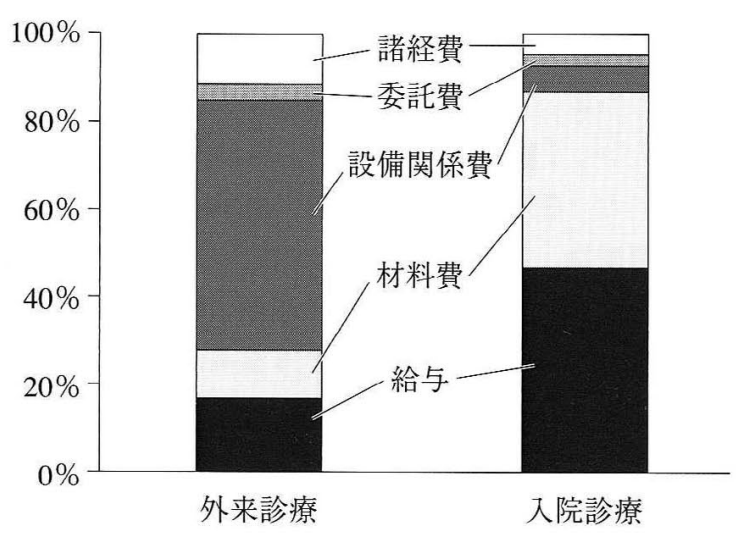

図 1 救急部の収支内訳

名が, 外来診療室と ICU 1 床, 一般病棟 3 床の計 4 病床 を運用している。

\section{3. 計算方法}

平成 16 年 4 月から 1 年間の宮崎大学病院救急部の外 来・入院患者を対象に HOMASに上る診療科別・部門別 原価計算を行い, 病院全体の平均值と比較した。勘定科 目は，国立大学法人会計基準に準じて，医業収益34項目 と診療経費 317 項目（材料費 18 項目, 給与 211 項目, 委 託費 24 項目, 設備費 22 項目, 経費 38 項目, 研修費 4 項 目）に分類した。診療経費のうち材料費 18 項目を変動費 とし，その他の経費は固定費とした。人件費は 1 週間の タイムスタディを行い, 大学職員の診療・教育・研究業 務のうち，診療相当分のみを計上した。また，光熱水道 費など直課できない経費はHOMAS 標準の配賦基準に基 づき矛盾のないよう案分した。

\section{結果}

期間中に救急部を来院した初診患者実数は外来 1280 人，入院 280 人だったが，レセプト上の患者数はそれら より少なく, 外来 1,132 人 $(88 \%)$ ，入院 105 人 $(42 \%)$ だっ た。救急部収入は，経過中の患者転科などにより，実際 より低く評価されている可能性が示唆された。

救急部の平均診療単価は，外来 12,739 円，入院 55,809 円であり, 病院全体平均 (外来 10,546 円，入院 46,109 円) を上回った。しかし，救急部の原価収支（医業収益：診 療経費比）は外来 1:3.4, 入院 1:1.2 と, いずれも赤字で あった。

救急部の医業収益と診療経費の内訳を図 1 に示す。医 業収益については基本診療料が外来 $25 \%$, 入院 $32 \%$ を占
め, 病院全体平均に比して高かった。これは, 時間外加 算のついた初診料や特定療養費, DPC対象外患者の特定 入院料が診療単価を引き上げた結果と考えられた。診療 経費については，外来で設備関係費が57\%と大きく占め たのに対し, 給与 $17 \%$, 材料費 $11 \%$ は小さ, 病院全体 平均と相反するパターンを示した。これは, 救急部の診 療経費総額が他科に比べて低かったが, 設備関係費に関 しては他科とほほ同等の負担を要したことが原因と考え られた。また，主な経費を $1 \%$ 削減した時の利益押し上 げ効果は, 救急部ではいずれも $1 \%$ 未満であり, 経費削 減による改善は期待できないことが示唆された。

損益分岐点分析では，各診療単価と固定費が一定と仮 定して外来 - 入院診療単独で全体の損失を補う場合, 損 益分岐点額は外来で 12,300 万円， 入院では 14,500 万円で あった (図2)。そして, 全体の赤字解消に必要な一日当 たりの患者増加数は, 外来患者 22 人か, あるいは入院患 者 5 人と試算された。

\section{考察}

HOMASによる分析では, 平成 16年度の宮崎大学病院 救急部は外来, 入院とも赤字経営であり, とくに外来診 療における損失が大きかった。外来診療では, 相対的に 高い診療単価と低い人件費・材料費にもかかわらず，赤 字となったが，これは設備投資に対する患者数の絶対的 不足に起因していた。コストの削減効果は期待できず, 患者を増やす方策が急務と考えられた。その際, 診療単 価は低いものの変動費率が低い一次救急外来患者の増加 がより効率的であり，一日当たり約20人の患者増加によ り赤字が解消されると試算された。

従来，原価計算は医療分野にはなじまないと考えられ 
SW4 救急医療の採算性
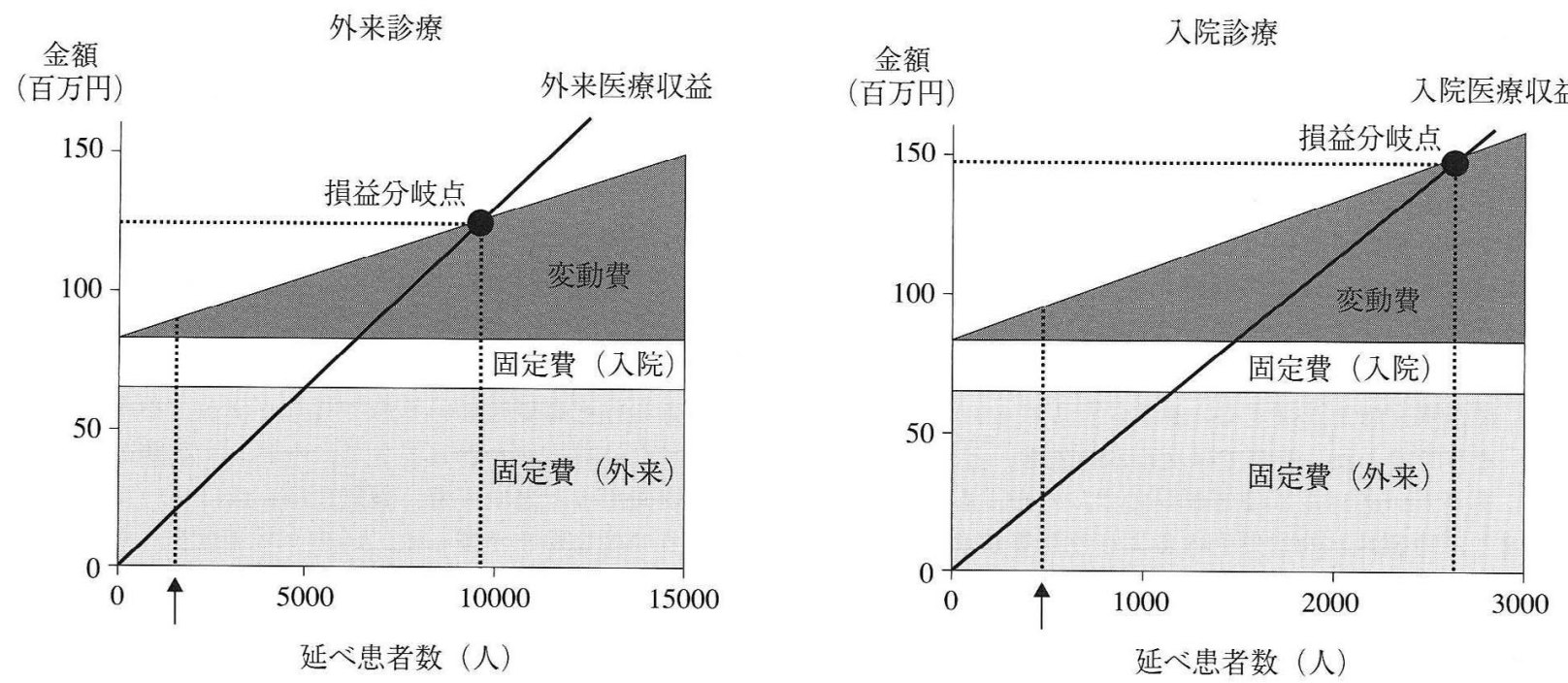

図 2 救急部の収支に対する損益分岐点分析 図中の矢印は実際の患者数を示す。

ていたが，近年，病院関係者に注目されるようになって きた。その背景には，DPCなど医療の標準化·効率化を 揭げる昨今の医療制度改革に，レセプトを中心とする従 来の収益偏重型の管理では対応しきれず，コスト管理体 制の強化が必要になってきたことがある。今回 HOMAS を用いて行った診療科別原価計算は, 救急部の損益構造 を理解し，問題点や改善点を把握する上で有用であった。 分析上注意すべきは，黒字·赤字という単純な「結果」で 診療科の優劣を判断するのではなく，どう改善したか (させるか）という「プロセス」を重視することである。
たとえ赤字部門でも，情報を公開し経営努力を説明でき る場合は，利害関係者の評価も高く理解も得られやすい はずである。

実際のHOMASの利用にあたっては，患者転科時の医 業收入の補正や，他科依頼による指導料・人件費などの 反映，他施設との比較時の配賦基準の統一など，検䚯す べき問題がまだまだ多い。しかし，HOMAS は救急診療 部門の採算性を向上する有用なッールとなることが示唆 された。

\section{DISCUSSION}

座長

聖マリアンナ医科大学救急医学 明石 勝也 宮崎大学医学部病態解析医学講座

救急・災害医学分野 寺井 親則

明石 大変おもしろく择聴させて頂きました。皆さん，お 立場, スタンドポイントも違うし, 病院の背景も全部違うと いうことがあろうかと思います。特に，たまたまですが発表 者のほとんどの先生方が国公立系ですので，どうしても赤字 のとらえ方が私ども，純粋な民間とは若干違うところがあろ うかと思います。俗にいう一般会計の繰入，赤字とは呼ばな い補填金のようなものが，だいたいの自治体病院に存在する でしょうし，それから減価償却の問題なども最近建てた新し いところは高いに決まっているわけですし，それからこれも 官民格差が非常に大きいということです。ですから拀そらく 議論としては, そういったものをネグるというか, 単純なス
トックについてはあまり考えないで，医業に対する収入と支 出，医業に関するキャッシュフローという形でご議論頂くの が，抒そらく公平な観点でものが言えるということではない かと思います。

寺井 明石先生から打話がありましたが，それぞれの立場， あるいは病院の性質等で，それがダイレクトにどうかという 話もまたあるとは思いますが, 初めに小さいところの, 自分 のところだけの医業収益ということに絞ってご議論頂きたい と思います。いま括を頂いたところでは，一つはカルテ等 がなかなか整備されていないので，ダイレクトに計算上でき ないという問題ももちろんあります。いろいろなところで問 題点があると思いますが，まず高岡先生から，そういうこと ではどういう点が問題点になっているか，あるいはどういう 点に力を入れて，いまやられているのかということがありま したら，お話し頂きたいと思います。先生のところは救急部 としてカルテはないのですね。

高岡救急部というものは存在しません。救急専任医が, 
病院全体が参画している救急の指導にあたっているという格 好です。カルテは一般の外来のものと同じものを使っていま す。

寺井於ですか。話は変わりますが, 先生のところは人 件費がえらく高くて, 発表の中にありましたが, 若手の医者 がメインでやっているということで何とか補っている。それ に対しては教育等で，ほかの価值を与えて動いているという ことだったと思いますが，そのプラスというか黒字は，絶対 額はそれほど大きくなかったですね。

高岡専任医が増えればすぐに赤字になるぐらいの額です。 寺井 そうですよね。それでは次の木村先生，どうですか。 木村 まず，一応カルテはございます。ただ，もともとが 支出のほうは時間外と内容を分けるような計算が全然なされ ていなくて, 勤務体制も, いわば診療科がやっている病棟当 直をほとんど使い回している状態で, 救急のために専従で 雇っている人間は看護師と, あとは研修医に何らかの宿直費 を与えてやっているということです。ただ，それを教育した り管理したりというものが必要だというので, 私が一人赴任 したという状況です。

寺井 木村先生のところと高岡先生のところは, どちらか というと外来主体のER といった夕イプで運営されていると ころだと思います。そういう意味では，ほかの先生方は若干 違うということになりますが, フロアの先生方で同じような, たとえばER 型のような外来のみで診療をやられている先生 もおられると思います。そういったところで経営に絞ってい えば，問題となることはどんなことがありますか。

宮庄福山市民病院の宮庄です。先ほど中部病院の先生に も㧍聞きしたかったのですが, 専従の問題ですが, やはり専 従をつくると赤字になるのかなという気がいつもしていまし て，結局各科がうまくERを回すというパターンでないと赤字 になるのではないかと，うちの事務長などとも話をしていま す。そこのところはいかがでしょうか。うちはやはり入院も あるので，その辺がいつも議論になります。専従医の給料の 話ですが，いま厚生労働省では救命センターだと勤務という 形になりますが, 勤務をすると一般のドクターよりも給料が 下がります。な扔かつ負荷が増えているということで, 下の 者もかなり文句を言いますし, マネージメントは非常に難し いといつも思っています。拉そらく専従医の方が, 先生のと ころですと夜間，されていないということですが, 夜間を勤 務という形にすると, 昼間はしないので, 給料は通常の基本 給だけで当直料はつかない。なおかつ勤務はする。ERは結構 たくさん来るし, 忙しいのに普通のドクターより給料は下が る，人を増やさないと当直という形で回しづらいのですが, 入れると赤字になる，そこのところのジレンマを非常に感じ るのですが，いかがでしょうか。

高岡先ほどのデータでは専任医の給料は実数で年収をそ のまま当てはめて計算していますが, 4.5 人で計算して, 現在 は当直をしていない。実際に当直をして24時間カバーしよう と思うと, 最低 5 人ないし 6 人の選任が必要になります。そ う考えると, 単純に加算するとその分赤字になってしまうわ けです。その辺はシフト制を入れて，時間外を抑制するよう にすれば，単純に人数が増えただけ給与費が増えるというこ
とでもないかなという気がします。来年度からは24時間常駐 する格好にするようです。

宮庄＼cjkstart少し話がずれますが，一般のドクターの給与ベース と, 救急に専従する医師との給与ベースはまったく同じです 加。

\section{木村同じです。}

宮庄先生のところはおそうく各科が全部救命センターに 集まってやられるので同じにしてもいいのかなという気も少 ししますが, 一般の, 通常のところですとERに行くドクター は，ある程度専従医という形で行きますね。そうするとその 先生にだけ負担がかかってきて, なおかつ勤務という形です と，夜間ずっと働いても，昼間に㷌れればいいですが，実際 は帰るのはなかなか難しく，いまうちではそれをうまくクリ アできないのが現状です。むしろ一般の方の給与のほうが高 い状態が頻出しているのです。

寺井＼cjkstart先生のところは低くなるのですか。

宮庄勤務という形で採ると低くなります。けれど勤務と いう形で採って, 夜間診た患者さんが悪いので残るのですが, たぶんどこもそうだと思いますが, ある程度カットというか, 救命センターになると勤務で人がいるはずだから長勤するは ずがないといわれてカットになります。

寺井＼cjkstart主に長勤分が差になってくるということですか。

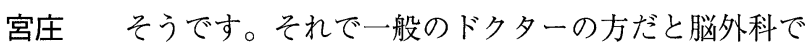
も，呼ぶと夜間来ても長勤がそのままつきます。ですから一 般のドクターはあまり急患に携わりませんが，ぐっと高く なって, 救命センターになる前よりもさらに下がったという ことです。下の者がものすごく文句を言ってくるので，どの ように経営したらいいのかなということです。

島崎杏林大学の島崎です。来年か再来年には厚生労働省 令で救命センター, ERを入れるかどうかは別にして，当直体 制をやめて勤務体制にしなさいということで，いま拐っ しゃったような夜間が勤務体制になるのですが, 当然下がり ます。いまのままの形ですと, 給料はかえって下がるという ことは当然起こってきます。ですから夜中に勤務すれば次の 日に帰るとかとせざるをえません。だけど実際に現場で，た だでさえマンパワーが少ないのに，それで帰ったらおそく救 命センターの輪番制でも引かないとやっていけなくなってい くような時代になるかもしれない。勤務体制が交替制に変わ れば，絶対に給料が安くなるから厚生行政にはぜひお願いし たいと思っているのは, 一つは補助金です。補助金は本来, 救 命センターに出るお金になっていますから，院内で薄められ ているのです。行政としたら救命センターに出しているお金 で，それが病院に入ったときに院内でどう使おうが，内政干 渉だから私たちは何も言えないということで，その拴金が全 診療科というかいろいろなものに使われているわけです。救 命センターが，夜間働いている者に対する保障のお金の一部 に使ってもいいのですが，それがまったく使われていないこ とに問題があります。東京都では小览救急の体制をつくって, 都から補助金が出ています。先日, うちへ来て小児救急に出 しているお金，補助金を小児救急に関連した診療にあたった 人たちだけに使うように, 病院側に指導をしていいですかと いう申し入れがあったのです。行政が補助金の使い道を指導 
するのは㧍そらく初めてだと思います。こういう形を救命セ ンターにも取れるような, 少なくとも東京都はその辺のとこ ろを非常によくわかっています。小児救急ですが, 救命セン ターのほうも三位一体の 3 分の 1 はいま出ていますから, そ れを抒そらく救急の中の補助金として救急だけに使いなさい という指導は，こういう実情がわかればいけると思います。 それは学会として, あるいは何らかの形で行政に申し入れな いと, 夜中に働かされて給料は下がる, 患者はいままで以上 に診ないととてもやっていけないということになったら, 手 も足も出なくなってしまいます。

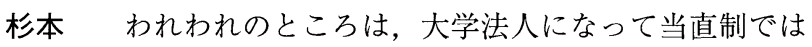
なくなりました。うちの当直料は大学は 2 万円ですが，それ がなくなったときから給料は減ります。長勤時間を実際に やっているのに制限するのがいけないのであって，それをき ちんとつけるように正してやることが大事だろうと思います。 夜であろうが昼であろうが，長勤になって，それでしなくて はいけないのだったら，本来つけないといけない。制限が あって，たとえば昨日も労働条件という話になりましたが, 三六協定を結ばれているから，それ以上越えて長勤を命令で きないのだからそれ以上払えないのではないか，という議論 になってくるという話だろうと思います。それは実際に，一 つは何といっても，もし長勤をしないといけないのであれば, 長勤料を払うのは当然のことであろうし，もう一つ，われわ れのところは，それでもなおかつ減るとしたら，たとえば救 命救急七ンター医師手当という形のことを考えないと, 人に 関しても需要と供給の問題ですから, 基本的にはそんなに給 料が安くてそんなことなら辞めようということに当然なって いきます。それを止めようとするなら，何らかの形でそれぞ れの病院が手当をしないと医師がいなくなってしまうという のは当然のことと思います。もう一つは，いま島崎先生が 扮っしゃいましたが, 補助金行政というのは常にそういうも のであって，それがどう生きるか生きないかというのはまっ たく関係ない，それを制限していくことは無理で，いくら回 せと言っても，回さずにやっていることはいま現実に起こっ ています。補助金行政をこれからいくら進めてもだめで，補 助金ではないものできちんとやれる形を考えるべきではない かと思います。

明石大変重要な問題だと思いますが，一つは勤務と当直 だと税制が違うところも大きいですね。当直はたしか 6 割ま では減免されると思いますが, 給与だとまともに課税対象に なりますから, 夜, 同じ額の手当が出ても, 手取りがずいぶ ん変わってくる。だから当直料のほうが高いという変な逆転 現象が起きてしまうことも問題ではなかろうかと思います。 それから（この場に防衛庁以外の行政の方はいらっしゃるの でしょうか, ) 補助金の問題はたしかに杉本先生が扔っしゃる と㧍りですが, 補助金は, 昔はつかみといってドーンと丸投 げでもらえた時代から，いまはだんだん使途が指定されるよ うになってきた。拉々らく島崎先生が扔っしゃるように, 本 当に救急医の手当に還元されているかとか, そこまで言及さ れるようにはなるのだろうと思いますが，もともとがくっつ けてもらっているのではなく, 赤字だから補填をするという のが補助金行政の本質ですから，いらないというためには黒
字でなければいけない。

島崎救命センターに出ている補助金は救命センターの中 で赤字にして, 補助金をもらっている。

吉岡 大阪府立急性期総合医療センターの吉岡です。いわ ゆる時間外をきっちりつけられるということは非常に重要な ことですが, 医師の場合はほとんどが管理職になります。そ のために時間外がつけられなくて, 管理職と通常の平の人と で逆転現象が起こってしまうというのが現状です。それで当 院は, 時間外をほとんど廃止してしまって, 重症管理当直と いうふうに名前を変えました。医師の時間外勤務は待機のと ころもいくらか含まれますので, 時間外よりは少し単価を下 げて管理職にも全部出すという形で，逆転現象を抑えること にしています。勤務になったときには, 勤務でつける当直者 というか従来の当直者の数を少し減らせて, 時間外でカバー する形を取れば，給料の減少は抑えられるのではないか，そ んなことをいま考えております。来年の 4 月から独立行政法 人化されますので，そのときまでに全部決着をつけようと 思っております。

田中 大阪大学の田中です。当初, 独法化になったときに, 長勤問題はかなり議論になったのですが, 労働基準法の縛り が非常に重くのしかかってきて, 結局, 働けど働けど労働基 準法によって長勤はここまでと, 非常に少ない額なのです。 いまそこをどう打ち破るかが問題になっています。研修医も アメリカと比べて40時間というのが非常にばかみたいな時間 ですが，ところがかなりそれを盾にシステムとしては動いて いるのが現状だと思います。労働基準法をいかに守る努力を しながら長勤を求めていくかが大きな問題にもなるのではな いかと思いますが，いかがでしょうか。

明石貴重なご意見だと思いますが，だんだん救急医の労 働条件と待遇の話になってきてしまったので, 昨日そういう セッションもありましたので, 全体, 組織として採算が取れ るのかどうかというところに, 少し方向性を戻していかなけ ればいけないかと思います。沖縄中部はたぶん, 先生のたび たびのご質問のように，うんと安い労働力でやっているから 黒字が出ている, でもたぶんあれだけ安い労働力で, それで も勉強になるからといって中部にたくさん人が集まってくる ということが, すごいと思います。寺井先生の施設が出して くださったように，収益を上げるのに数で上げるのか，患者 の単価で上げるのか, つまり重症な患者ばかりを診ていくと いいのか, 数を診るといいのか, それから森田先生がおっ しゃったように，経費をどんどん抑えていくのか，3つとも大 事なのでしょう。数をたくさん診ていくのが比較的いいと おっしゃる先生方と, それから川口のように, 単価の高い入 院患者を集中的に入れて収入を上げていくと黒字になるとい うこともある。つまり, 興味があるのは外来を中心にやって いく救急のスタイルと, クリテイカルケアを中心でやってい く救急のスタイルと, どちらが採算性がいいのかなというこ とを, 少し発言して頂けますか。

寺井 ただ, 地域によって, たとえばだれもウォークイン の患者で上げようと思わなくても, 結局それが来るという形 でなっているだけで，いわゆる地域のニーズを反映している だけだというようにも思います。たとえば小関先生がいわれ 
るような，重症患者が集まってくるところはそういう形でや るほうがきわめていいでしょうし，そうでないところはやは りウォークインの患者で, できるだけ採算性という形で持っ ていって，その反映が単に出ただけだろうと思います。たた， 問題になっているのはERのときでは，たしかにそこの小さ い, 直接収益だけでいえばトントン, ないし赤字かもしれな いけれど，逆にいえば結局，間接経費はかなり大きなウエイ トを占めているという形で評価しないといけない。ERはこれ だけでせいぜいだからいけないというのではなく，たとえば 木村先生のところもありましたが，そのかわり紹介率をかな り上げているということです。そういった面で，見るポイン 卜は若干違うのかなと思います。

島崎いいまの明石先生の括話で, 参考になるかと思います が, 北米のER型救急をやっていますね。医療経済を論じた論 文があって, ERを持つ病院の収入として, ERと入院重症患 者, いわゆる救命センター型に患者を入れる理想的な割合を 出しています。ERの患者が50\%ぐらい, 二次救急患者で入院

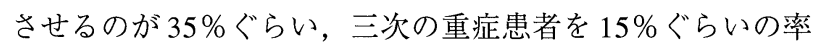
で, 外来あるいは入院させると比較的病院経営としては理想 的な収入が得られるという内容です。参考までに。

寺井 いまお話の中で, ERのところは一応終わったので, 今度は完全型かどうかはともかく, 救命救急センターを何ら かの形で抱えている先生方で, 先ほどあったような直接収益 のあたりについてお考えを伺いたいと思います。まず川上先 生からお願いできますか。

川上 やろうと思えば救命センターの収益自体はいくらで も上げられますが，ただ，それに対する支出などが非常に問 題になってきます。たとえば先ほどの循環器の問題でも, た しかに循環器は稼ぎ頭ですが，材料費もべらぼうです。本当 に儲かっているのかといわれると, 微妙なところがあります。 収入も増やすように努力するのであれば，支出も減らすよう な努力もしないといけないということです。先ほど岡本先生 が言われた，患者数も増やす，それから固定費を下げるとい うことは人件費を減らすということですが，それもやる，と いうことはわれわれの病院は全部やっています。全部やって 到達したのがいまの形です。ICU自体は, 救命救急センター といいながら院内のICUも兼ねていますので, 8 床あります が 6 対 2 で, 全体の救命センターの収益自体は, 出していい のかどうかはわからないので言いませんが, 先ほど小関先生 が言われたよりは金額としては上です。回転率というか平均 の在室日数はICUで 3 日です。重症か否かは関係なく, 救急 を取るために出してもらいます。それをわれわれがコント ロールしている。10床つくっていて認可されたのが 8 床なの で, 実は2つ空いていて, そのうち一つが稼働しているので, 夜中 9 床ということはあります。でも, 朝になったら出てい きますから稼働率自体は常に $100 \%$ を越えるように持って いっています。そこでやっていて困ったのは, 昨年の診療報 酬の改定です。それは高額ベッドから定額ベッドに移行した ときの高額算定料が取れないというもので, 厚生官僚はすば らしいところに気がつくなと思いますが，われわれのところ は3 日ということは 2 日分しか取れない, もろに 3 分の 2 掛 けになります。その査定が出たときに，5,000万から 1 億円ぐ
らいの損益が出るのが決まってしまって，実際にはいろいろ 努力して損益が出ないようにしました。私が言いたいのは, 今度 4 月にも改定しますが，そういう救命センターだけでは なく, 諸処の診療報酬の改定であるとか, 病院の経営である とか, 研修医の問題とか, そういうものを全部加味したうえ で，なおかつ先生がおっしゃられたように，その地域のニー ズは何か, 病院の方向は何か, 患者の分配度はどうか, 内因 性が多いのか外因性が多いのかとかを含めてベストのところ をそれぞれの施設が探して持っていかないと，なかなか難し い問題ではないかと思います。われわれのところは，先ほど 出た勤務体制などは，はっきり言って全部クリアしています。 病院の収益もいい。それは事実ですが，それがいまの状態で いいというだけで，これは 2 年前に札幌での学会でもありま したが, 次の 2 年後に杉本先生が会長をやられますから，そ のときに，まったく逆のこと，うちの病院は全然だめですと 言っているかもしれない。そういうものだと思っています。 寺井 それでは小関先生, 扮願いできますか。先生のとこ ろは傾きをかなり上げて, いわゆる一患者当たりの収益をか なり上げて成功しているという発表だったと思いますが。

小関誤解されては困りますが，収益を上げるためにやっ ているわけではなく，このワークショップの一番の目的は 「明るい未来を拓くために」というはずで，僕は別に金計算が 得意でやっているわけでもないし, 診療のアクティビティを 上げることを目標にやってきたわけです。その結果がどのよ うに出るのかというのを, 救命救急センター, あるいは救急 医として知りたかったわけです。収益はきっと青梅市立より も少ないかもしれないけれど, こういった結果が出るという ことを証明したいだけです。いまずっとお話にあったように， そんなに細かい計算をしてどうこうということではありませ ん。少し雑の話で申し訳ないのですが, そんなことです。で すからうちの病院全体の経営は決してよくなくて, 収益もよ くないのです。自治体病院の典型的なものですから, その中 で救急医が独自のスタンスでアクティビティを持ってやって いるということで，それが目立つわけです。ですから診療科 の中で 4 位を維持しているというのは，あるいは内科に次い でほとんどナンバー 2 ぐらいでやっているというのは，「明る い未来を拓くために」やっているわけで，収益を上げるため にやっているわけではないということです。

明石 小関先生, 一つだけ教えてほしいのですが, 病院全 体ではあまり収支がよくない，それはたぶん川口市民の税金 が入っているのだと思いますが，そうだとすると先生のとこ ろの救急が, 頑張っているけれども少し赤なんだといって補 助金をもらうということは, 病院全体にとってみると便利か と思うのですが, それがやや，俺たちが頑張っているのたか らもらわないとという，とばっちりはどうですか。

小関 そうではないですよ。私は胸を張って言いますが, 病院の経理のほうでいくら計算しても救命センターが赤字に ならないのだということで，その結果で言っているのです。 ですから支出の分に関しては，相当な按分でやらざるをえな いわけです。その結果が, この数年間は何度やっても赤字に ならなくて，病院としては損をしているわけですが，私とし ては胸を張って黒字だ言っているわけです。それではだめ 
ですか。

明石いやいや，よいと思います。たとえば一般救急外来 の看護婦さんは別働隊で人件費は入れていないというのを， それも救命センターも手伝っているのだといって, 人件費を 救命のほうに乗せれば，5,000万円ぐらいの赤はすぐつくれる と思います。

小関＼cjkstart私が院長になったときには赤字にします。(笑)

川上補助金ですが，われわれのところは設立当時から国 の補助金はゼロという条件でやっています。3分の 2 のうち 都がということで, 普通 3 分の 2 もっているところが 2 分 の 1 なのですが, 別にマイナスだからといって, ないと出さ ないわけではなく，一定額より少なければ収支がマイナスと， 向こうの勝手な係数が出てきますね。面積当たりの単価でい くらと, それに対してと出てくるだけなので, そこに持って いくように考えればいいかと思います。独立型の場合は難し いのですが，併設型がやっているのは，やはりどこまで救急 かというのはグレーですから, 人件費を増やそうと思ったら いくらでもできます。循環器の急患が来て, われわれが診て もやっているのは循環器で, 循環器の医者もICUだろうとい うふうにやればできるわけです。それは算術の話になってし まう。ちなみに大垣市民病院の院長先生に言わせると, 俺は 補助金なんかもらわない, それでもやっていけるということ ですが, あそこは年間, 救急外来数は 7 万人です。救急車は 8,000台ぐらいだと思います。

寺井 ありがとうございました。能力のある院長先生が来 られているので，(笑) 発言を伺いたいと思います。

森田私は能力があったわけではなく, 職員が非常によく やってくれたということですが, これでも正味の救命救急セ ンターで, 純粋にどれだけいるかということを，おそらくア ピールできたのかなと思っております。また薄氷を踏む思い です。地勢学的に, これはどう変わるかわかりません。たと えば卑近な例を出しますが, 中谷先生に非常に悪いのですが, 関西大が近くにやってくる。そうしたら, 目と鼻の先ですが, 㧍そらく患者数は減るのではないか。それを仮にゼ口にする と, 2 億弱の, 今度は逆に赤字にいってしまう。そういう非常 に変動の大きいところで, なかなか安心して医療がやってい けないという条件もあります。ですから先ほど冒頭言われた

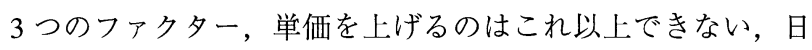
当点が 11,000 点ですか，入院患者さんの一人当たり 110 万， 120 万円，救命センターとしてもこれは無理だということです。 経費を抑えるファクターですが，これについては先ほど申し ましたように，薬剤費をほぼ半減できたというところで，こ れ以上下げることはできない。やはり腸管を使えないケース においてはIVHをやらなければいけない。当然のことですか ら，何\%かやって扬ります。しかし昔はことごとく重症だか ら，ほほ全員にやっていたといういきさつがありまして，内 科医の私からみたら, ちょっと……感染も 2 次的にゼプロ ミス, それから臓器障害というのを嫌というほどみてまいり ました。私はこれはおかしいのではないかという思いでみて おりましたが, なかに非常に優秀な医長がおりました。欧米 の論文をことごとく検索してくれて, 経腸に変えましょうと 提案しました。それ以降, 優秀な医長が多くの患者に対して
経腸栄養を実験してくれました。先生，これはいけるのでは ないかということです。そうしたら，薬局長も乗ってくれま して，医療費がだいたいこれぐらい減ってくるという試算を してくれました。…..。

(録音中断)

……ということで，われわれはまた危機意識を持ちつつあ ります。どうすればいいかということをいま考えているわけ で, 三次救急に特化するのではなく, うちの病院の横に夜間 応急診療所, 初期救急がありまして, それは医師会が三島救 急医療センターに委託しておりますので，医師会と調整を取 $\eta$, ER部門と三次救急を併せ持った, 総合的な救急医療セン ターにして患者数を増加させたいと，個人的にはそう思って います。それから，それだけで果たして来るかということに なると問題なので，いま変則的にやりつつありますが, ドク ターカーのマンパワーがもう少し充実されたら，こちらから 患者を待つのではなく拾いに行くというふうに，ER部門と三 次部門を若干分けまして，こちらから患者を中谷先生のとこ ろまで引き取りに行くというふうに考えております。患者さ んを増やさなければ収入は絶対にありえませんから，そうい うことをしていかないといけないのではないか。それから夜 間応急診療所も一部使わせて頂いて, 昼間から救急の患者さ んを診ていく。ただ，医師会との軘轢があるかもしれません。 職員には非常に過剩労働を強いるかもしれませんが，それは それなりに今後手当を考えて，ER部門をもう少し充実させ， その専門家にバトンタッチという流れのなかで存続させてい きたいと思っております。

寺井たしかに経営的状況はいいといいながらも, 先ほど 言われたように, 何かポンとほかの病院ができると一気に潰 れるというようなことから，不断に経営改善を念頭に置いた システムを組まないといけないということで, 岡本先生に HOMAS というッールを出して頂いた。これによって不断の 経営改善, あるいは現在何が弱く，どうすれば今後できるの かというような，いろいろな条件が出るということもあり， 国立大学ではすべて入った。今後それを売りに出して, 全国 的に広まる可能性もあるというところでお話を頂きました。 岡本先生, 夕イムスタディというのはほかの一般の病院でも 使うような概念ですか。

\section{岡本ほかの一般の病院というのは。}

寺井大学でなくても。

岡本実際はコンピュータに各自入力するような感じにす ればいい，それが一番効果的かと思いますが，ある期間を定 めて, どこの科，どこの場所で働いたということです。ただ タイムスタデイが生きてくるのは，多くの場合は国立大学と か, いわゆる研究診療教育などいろいろな業務をやっている 場合とか, あるいはいろいろな科に呼ばれて, どこかの科で 働いたというものを分けて使うためにやるものです。たとえ ば看護婦さんとか，ほかの一般職員の方は，計算するのはそ れほど難しいものではないと思います。それから各病院だけ のデータだ，かなりいい加減というか，概算になってしま うので，たとえばHOMASの場合は 41 大学にありますので, 各大学のタイムスタディの結果を集計して, マッチングさせ るというシステムをオプションとして持っています。 
寺井 ありがとうございました。いま現場，あるいは実際 に働いている先生方から経営に関するコメントを頂きました が, いや，そうではないと，経営の面から一言言いたいとい うことで，明石先生からお願いします。

明石われわれのところでいま原価計算の仕組みを立ち上 げているので, HOMAS というのは, へえっと思って聞いて いましたが，いまおっしやったタイムスタディは，いくつか の病院でやったところを知っていますが，分析をするにはす ごくいいのですね。でも，改善をするのにつながらないとい うのが大方の意見で, 結構難しいところがあります。それで, やるとすごい手間とお金がかかります。だから慎重にやられ たほうがいいかなと思っていました。実は今日，いろいろな 方の意見で直感的に思ったことと，だいたいそうだなと思っ たのは，ERは数をやるけれども，なかなか収支バランスが合 わない。けれども併設病院の間接益はすごく大きい。たぶん 今日, 岡本先生と先生が用意してくださったスライドの輪の 三つのうちの一番外の輪まで影響があるのが ER ではないか と思います。片や，クリティカルケアもすごく収益性が高い なと思っていました。ですから，森田先生に聞きたかったの ですが，先生のところみたいに独立型で，いま先生のご努力 でだいぶいいところまできたというところが，さて，ER的に 外来患者を増やすと, 併設の母体病院がないだけに, 直接の 損が増えてしまって益が増えないという可能性はないのです か。

森田直接の病院を持たないというのは, バトンタッチを して，二次の患者を，しっかりした医者がとりあえずすれば いいわけで, これも二次であれば二次で回す。そして私の構 想は一次, 二次, 三次ではなく，一，三，二というものです が, 完結しているのです。たとえばERで三次が必要だとなる と，バトンタッチします。そこで治療はすでに完結させます から, 総合病院と同じレベルと考えて頂ければいいと思いま す。ですからそういう状況で, どの程度そういうことをやれ ば赤字になったかというのは，まだ試算しておりませんが， 私はこれでぜひとも何とか黒字に持っていきたいと思ってい ます。

明石〔どちらなのか, 僕だったらどうするかと迷いながら お聞きしていました。

森田たた，私自身はもともと内科の救急をやっている医 者ですが，やはり患者の立場に立つと, やはりそれをやって あげないといけない...

明石 ERの部門とクリティカルケアの部門と, そろばん上 のデメリットもそれほどはなく, 間接益も含めると, 今日の 演者の皆さんも結構頑張っているというなかで, ときたま耳 にする, 木村先生の発表もそうですが, 院内逆風の病院があ るというのは何たることかと思います。そういうことすら理 解していない院長がやっているのが, そもそもけしからんと 思います。そういう病院は結構あるのですか。

前川関東中央病院の前川ですが，それとは別に，実は救 急医療の採算性は問題になりますが，私どもの病院は国家公 務員準拠なものですから国家公務員に右へ做えで，おそらく 地方公務員もすでに採用されているところもあります。たと えば東京都もそうですが，これから考課主義に基づいた人事
考課というものが入ってきます。そうするとそこでは採算性 が問題になってきます。その次にくるのは, ここ 3 年から 5 年後には, 管理職以上は年俸制度になるかもしれませんので, そうなると皆さん方が頑張っていらっしやることが反映され るところは反映されるでしょう。ポジティブで反映される部 分が圧倒的に多いとは思いますが，ネガティブになるところ もあるかもしれません。そういう意味では, 今回のような機 会で，お互いに救急医療の持っている経済的な側面を議論し ておいたほうがいいと思って, 扯聴していました。老婆心か らちょっと。

寺井 そういうときに, 何らかの数字目標を出さないとだ れも納得しない。これはもう間接的にやっているだろう, 紹 介率は上がっているはずだと, そういうときに先ほどあった HOMAS など, いろいろなツールを有効に利用して, 第三者 の説得材料にすることをしないと, いつまでも, いやいや一 生懸命にやっているのだといったことだけでは, だれも納得 しない。そういうことで, 岡本先生に出して頂いた。それか らもう一つ, HOMASについて少し言うと, たとえばわれわ れのところも患者を取っても, 勝手に救急が取って, なぜう ちが診ないといけないのかなどという話がありましたが, HOMAS で各診療科ごとにズラッと出ます。だから弱いとこ ろは，いいですよ，うちで取りますからと，そういう間接効 果もまた出てくるということです。数字を公開し, それに よって競わせる，そうすることによって救急部門はかなりメ リットが出てくるのではないかということです。先ほど年俸 制のこともありましたが，そういうときにも数字がすべてを 動かしますから, ぜひともそういう形にする。特にカルテが なくてなかなか苦しいという場合でも, やはり何らかの形で そういったものがダイレクトにできるような指標をつくらな いと, これからはなかなか難しくなるのではないかというの が, 個人的な意見です。センターのことについて若干問題が あると思います。それはわれわれの田舎もそうですが，たと えば長期患者がセンターを占拠する。老人で, CPAで蘇生し てだれも取ってくれない, というようなことが多くのところ でよく聞きます。その辺について，いわゆるドレナージです が, 初めの枠組みのところでも少し話題が出たと思いますが, そういったことについてどういうアイデア，あるいは工夫を されているのかというのをお聞きしてみたいのですが。どな たかおられませんか。いわゆるドレナージ病院, たとえば頸 椎損傷, 枠組みのところでもそういったセンターをつくるべ きであるとか, 熱傷センターをつくるべきであるといった意 見も出ていましたが，現実的にはなかなか苦しい状況の中， 在院日数を減らす，あるいは新たな患者を取るためにはどう してもそれを何とかドレナージしないといけないということ が，切実な問題になってきていると思います。何かそういっ たことについて, こういうアイデアがあるとか, こうしたら どうか, あるいは行政にして頂きたいということがあればお 願いします。

森田 三島地域, 高梘市, 茨木市, 捸津市, 島本町の人口 170 万人ですが, 比較的, 民間病院が多いのです。総合病院と いう 300 床前後の病院が結構あります。まだシステム化はさ れていませんが, 何かの会, 懇親会や飲み会などで個人的に 
院長同士で話し合ったり，急性期をすぎたら，リハビリテー ションにしても, 送ってくれという院長先生は結構扔られま す。そういうところで, 三島のほうは結構ドレナージが利い ています。それからもう一つは，一昨年から大阪府の対策だ と思いますが，脳血管障害後のリハビリテーションまでの一 貫したフォーマットをつくりまして，お互いに病院同士の連 携を高めていこうというシステムができあがっています。そ れにのっとって三島救命センターからも, 特に脳障害患者さ んが長くなりますから，それに関しては次の病院，次の病院 という形で，一つのシステム化されつつあります。

寺井地域連携を介してのシステム化ですね。

森田地域連携ですね。それともう一つは院長同士のなれ 合いというか, 顔の見える関係, 飲食の席で頼んでいるとい うことです。

寺井々ういった話が出ると, 必ず地域連携で何とかしろ という話が出ますが，現実はなかなか取ってくれるところは ない。酒の席の関係ということももちろんあるでしょうけれ ども。

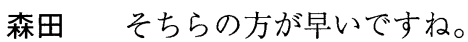

寺井 ほかに何かありますか。

島崎医療収入, 医療経費は別にして, さしあたって医療 収入ということで, 地域の問題やいろいろな診療形態などで 違うのでしょうが, 基本的に救命センターに入ってくる, つ まり重症だけを取り上げている立場からすると, 入ってくる 患者は主に循環器内科と脳血管障害と, それからわれわれが 救急として扱っている患者がビッグ 3 です。それを救命セン ターの収入とするのか，あるいは特化したものは各診療科に 全部渡してしまうのか，それでものすごく違ってきます。独 立型のところは全部自分のところですから，おそらく黒で やっていけると思います。ところが一般の救命センター各科 に特化したものは各科の収入という形にすると，ちなみにわ れわれのところなどは循環器内科と脳神経外科がトップ2を 10年以上続けている。それは救命センターを通って入ってく る件です。だけど計算上では, 救命センターの患者をそれか ら引き算してやっていくと, ちょうど真ん中ぐらいになって しまいます。だから収入のランキングからするとそういうこ とになりますが，いま言ったいろいろな面で救命センターは 病院全体に寄与していますという話は, 病院全体から考える とそれでいいという話になるけれど，救命センターの収入， あるいは救命センターが赤にならないというのは, どういう スタンダードでしゃべるかをある程度決めておかないと，そ れぞれの診療形態なりお家の事情でかなり違ってくると思い ます。その辺を押さえて救急をやればいいわけです。救急は 何もわれわれ救命センターでわれわれに特化した患者を診て いるのではなく，いま言った脳神経，ストロークやCCUの患 者もかなり大きなウエイトを占めていますから，その辺も少 し考えて頂きたいという気がします。

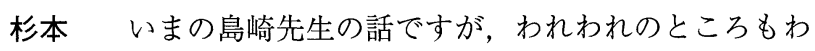
れわれのところに入って, たとえば循環器内科にいって退院 する, そして循環器内科にレセプトが全部つながっていくと いう形を去年までやっておりました。それが今年から，コン ピュータで処理しているのだから, 救命センターに入ってい
る間は救命センターの収入としてやれないはずがないという ことで，ほんの数日ですぐにできました。院内的には簡単に できることで，それをどうするかということでやっていかれ るのが一つだろうと思います。それともう一つ, 少し話が変 わるかもしれませんが, 大阪府に関していえば, 救命救急セ ンターは別にレセプトも集めて, 別にやっている。これは標 榜科じゃないからできないというわけではなく，そこでやろ うと決めればできる話で，われわれのところはそうしていま す。もう一つ, 森田先生のところは大阪府が多いと思います が, 独立型の救命救急センターがあるわけですね。片方では 病院の中に併設で, 初期も含めてかもしれませんが, 病院全 体として運営されているところ, あるいは先生のところのよ うに自己完結型であるとか, その 3 つの形がありますが，そ れぞれ特徵があるだろうと思います。私は大阪府の人間のせ いもあるということですが, 独立型の救命センターは, 森田 先生はそういう形でやってたしかに経費は減ってきましたが, どんなに頑張っても黒字化することは不可能ではないかと思 います。人の使い方という意味でも非常にむだが生じてくる し，そう考えていったら独立型を解消して，併設型でやるの が当然ではないかと思います。その辺についてどう考えられ るかということです。

森田先ほど小関先生からもありましたが, 併設型にして も独立できるような条件でないと, うまく常在の各診療科が 理解してくれるかどうかは非常に難しいと思います。私はや はりユニットとして併設の中で動けるようにして頂くのが

杉本々れは努力の問題であって, 併設型の中で病院一体 型の運営をやっているところはいま全国で非常に多いです。 私のところは森田先生とまったく同じような形で, 自己完結 型で長い間やってきました。こと外傷や外因性に関してはわ れわれだけで十分ですが，もし内因性の疾患等を含めてやる と考えれば, 院内に循環器内科や脳外科, あるいは脳卒中の 人たちがいたら, 当然それを入れてやるほうがうまくいくの は間違いありません。だから三島のほうで, 自分たちだけは 黒だいう形で……正直言いまして，実際に先生のところ にしても黒字化できたとおっしゃっているけれども, これは 高槻市民の税金を放り込んでやっている部分を無視して黒字 だという形になりますから，そう考えると，やはり効率性も 考えないと, 長期的には救急医療を維持していくのは, 要す るに市の財政の状況によって左右されてしまうのではないか と危惧するわけです。

森田当然, 高槻市民の税金が大半ですが，それなりに安 心して頂けるような救急医療をやらなければいけない。われ われにはそれも課せられているということと, それからやは り併設型にするほうが, マンパワーの面やいろいろ医療器具 の面など，非常に効率よく使えるということがあると思いま す。ユニットできちんとその部分が完結してくれないと, 中 途半端な治療になってきはしないかということです。もちろ 几院内の努力ですが，私はそれを危惧しております。

寺井 わかりました。独立でやっている場合には, アカウ ンタビリティというのですか, 説明責任と公開が前提になる のだろうと思います。 
森田私どもは決して黒字ではありません。補填のうえで の黒字で何とかやったということです。

寺井今回この場では出ませんでしたが, 近い将来, 導入 されるであろうDPCに関して, 島崎先生, それについて今後 の方向性と救急の採算性に関してコメントして頂ければと思 います。

島崎いま特定機能病院のほとんどがDPCにすると, さし あたってはトータルするとどの診療科も少し黒になるような 形にはなっています。ですが，おそらく最終的にはそれが集 約していく。というのは，いままでの収入に係数を掛けて請 求できるようになっているのですが， 1 年間のうちの 7 月， 8 月，9月分の収入をDPCの平均にするのです。ですから 7 月， 8 月，9月分を非常にたくさん収入を上げると，DPCの係数が 上がります。ほかのところは下げておくとDPCの収入がたく さん入ってくるという, 非常にマジックみたいなことをやっ ています。DPCになると, いろいろな面で, 従来の出来高と 比べると最終的には落ちてくる，医療収入としては首が締 まってくる方向になるのではないかとみています。もう一つ， われわれは重症患者を診ていてと思うのは，最重症の患者が DPCでやられると，医療収入面としてはあまりよろしくない。 それではどうしているのかという話になると, 同じ病名の比 較的軽い患者でまかなっているというような格好になります。 まだDPCをやるときの問題がいろいろあって，たとえば外傷 の点数などはむちゃくちゃです。もともと外傷をやっていな い人，どうも内科の先生がアメリカでつくったものをそのま ま持ってきているようなところがある。それでMDC16という ところがわれわれの持ち場の外傷や熱傷, 敗血症, 薬物中毒 というところですが，それの点数は，実際にやった透析など， いろいろな処置に関しては一部DPC，残りは手術と同じょう な出来高が入るようなシステムにおそらく変わると思います。 先々月ぐらいまでで，そういうものを行政と一緒になって決 めたから変わると思います。質問には答えられませんが，全 体としてはそんなところだと思います。

寺井 DPCというのは在院日数で 3 段階で分けて, 初めを $15 \%$ 上げる，第 2 期は $15 \%$ 下げる，さらに 3 期は下げるとい うことで，重症になればなるほど赤字が膨らんでくる。特に 早期にボーンと，そういうところが問題になっていたという ことです。

島崎 それから重症救急加算はいま 1 万点強ですが，あれ がDPCになると八千数百点，ただしその上にDPCのものがつ くという格好になっています。それでも重症救急加算は減っ た格好にはなっています。

寺井しかし，それは改善している方向に動いているとい うことですか。

島崎さしあたっては多くの病院は，極端な話でいうと， もちろん査定で問題になるでしょうけれども，軽い患者ばか りを診ているほうが収入としては得をするのではないでしょ うか。最重症ばかりを受けてまともに診療していると, はっ きり言って損をするような形です。

寺井 ありがとうございました。いままでのお話を伺って いると，コスト意識はもちろん大切で，いままでのようにコ ストをまったく念頭に置かずにすることはもはや無理だとい
うことが一つです。それからもう一つは，先ほどDPCの話も ありましたが, 医療の報酬に対しても, 今後, 学会としてそ れなりの発言をして頂かないと, 黙っていたら, それこそ目 減りしていくということです。そういった意味で, 自分のと ころのコスト意識を高める, そのためのツールをぜひともし て頂きたい。それから医療報酬上の加算はそれなりにつけて 頂かないといけない。何もそれ以上にしろとは言いませんが, 実態に即した形でして頂く。それともう一つは医療供給体制 をそれなりに，われわれのほうから具体的に，こういったこ とをしてもらいたいというスタンスは, 今後, 必要なのかな と思っております。

明石私もそう思います。今日の最初のスライドは名作だ と思いますが，地域の信頼性といったところまで論じないと 救急医療の採算性は語れないのではないかと思っていました が，実は医業のところの採算性，それからせいぜい病院全体 の収支といったところまででも，救急部門や救急医療という のは，でたらめな不採算の部門ではないということは皆さん のお話を聞いて思いました。その輪の中でも採算を取るよう にみんな努力をしているということもわかり，大変よい集ま りだったと思います。いま，国民医療費が31兆円だそうです。 20年たつと60兆円になってしまう，大変なことだということ で，国民医療費の縮小，削減に向けて努力しています。これ 以上補助金が減ったりすると困る, 診療報酬もそうですが, たた，やはり国の財源を守るために，われわれも救急は不採 算でいいのだから何をやってもいいのた，薬もカテーテルも 使いまくりというような医療が許されるべきではないと思い ます。今日は議論になりませんでしたが，われわれはそうい う意識で若い人も指導していかないと, たぶん救急医療, あ るいは日本の医療の将来が危うくなってしまうのではないか と思います。

寺井小関先生が言われましたが, これは本来, 明日の救 急医療のためにということでつくったものです。簡単に救急 医療は赤か黒かという言い方をすれば，十分にポテンシャル はあるということで, 今日の話し合いの中で十分なコンセン サスが得られたのだろうといういうことです。そのポテン シャルをどのように具体化していくのかということになって きたときに，やはり先ほど言った診療報酬を実態に合った形 にして頂きたい。あるいは医療供給体制をそれなりに，何も 救急にいいようにとは言いませんが，きちんとしたリーズナ ブルな形でして頂くようなアプローチをして頂きたい。まっ たく自分たちでやっているから，いま黒だから何でもいいと いうものではなく，常にそういう形で関係されている，たと えば行政であるといったところに学会を通じてアプローチし て頂きたいということです。そういうことで，このセクショ ンを終わりたいと思います。

平成 17 年 10 月 28 日 


\section{SW $4 \exists \times>F$}

聖マリアンナ医科大学救急医学

明石 勝也

\section{救急医療の採算性について}

救急医療の採算性をどの局面から捉えるかということ が, 本ワークショップを通じての大切な論点であると思 われる。国民医療費の高騰が国の経済自体に深刻な影響 を及ぼす昨今にあって, 救急医療にも経済性の論理が導 入されることは止むを得ないことであり，節約の発想は 確かに必要である。しかし単純な診療収支だけでは十分 な収益は期待できないことから不採算医療として公的補 助の対象となってきている救急医療には, 社会共通資本 としてなくてはならないものという側面が大きい。加え て近年の医学教育細分化, 病院医師不足を考えると専門 施設での救急医療教育も, 採算性という観点からは議論 できない社会経済性が存在すると思われる。

最近になって病院にも導入し始められた管理会計の仕 組みでは救急部門単体の評価が比較的容易に行えるよう になっているが, 救急部門を経由した一般病棟入院患者 から発生する収入などを細かに分離することが大変難し い。多くは救急部門の業績としては見ていないと思われ る。しかしながらこうした間接効果が病院全体の収支を 考える上では大変効果的であり, しっかりした救急部門 の病院全体でのバックアップがあれば病院収支の決め手 にすら位置づけられるはずである。救急部門の責任者よ りも病院執行部に救急部門の管理会計による経営指標以 外の効果を理解できる人材がいるか否かが採算性の鍵で あるように常々考えている。各演者のご発表に若干の私 見を述べさせていただいた。

\section{SW4-1 完全的ERの採算性}

特徵的な研修医, 指導医の構成で, 十分数の救急外来 患者の診療にあたり, 独自の収支でも採算性を保ってい る。豊富な患者数は地域からの信頼の証であり，たくさ んの研修医の参画という教育効果の二つが収支に現れな い付加価值として素晴らしい。十分, 経営上のメリット ありと考えるべきである。

\section{SW4-2 二次救急医療は本当に赤字なのか}

ご主張のように二次救急医療を赤字と見るか, 否かは 見る側の考え方次第で, 救急部単独の収支以外をどう評 価するかが病院運営者にかかっている。ただ，受け皿た る母体病院の性格によっても救急医療収支の評価は大き
く影響を受けざるを得ない。例えば地域医療支援病院で あるがために紹介率に敏感な施設では救急患者増があま り高く評価されない可能性がある。制度上の矛盾とも言 えよう。

SW4-3 自治体病院併設型救命救急センターにおける救 急専従医の採算性

救急専従医とその他診療科医師との病院をあげての連 携が充実すれば，地域の救急ニーズにもこたえ，十分な 採算性が確保されるという好例である。外来患者数も含 めて，ある意味で理想的な救急医療施設運営と言える。

SW4-4 自己完結型運営による救命救急センターの収益 と採算性

他の発表と異なり, 自己完結型で十分な入院病床数と 重症度の高い症例を取り扱う救命センターの収支として 興味深い。高収益型救急医療施設と言ってよからう。一 つの雛形として考えられるが，この救急診療形態をとる ことのできる地域はある程度限定されるのではなからう か。また軽症者の受け皿など地域連携にも十分な配慮が 必要であろう。また運営にあたって人員配置などもかな り厳しく見積もってあり, 経営努力が収支好転に見て取 れ，参考にすべき内容である。

SW4-5 独立型救命救急センターの運営実績からみた経 営分析

独立型救命センターでの厳しい経営環境の実態が明ら かにされている。地域における役割と主として取り扱う 疾患群との相違によって公的補助なくして成り立たない という普遍的課題が分析されている。自己完結型と似て 非なる独立型の厳しい状況といえよう。

SW4-6 国立大学病院管理会計システムを用いた救急医 療部門の収支分析の試み

管理会計の仕組みが病院に続々導入されている背景は, 厳しい経済環境だけではなく，広く病院に普及したhospital information system（HIS）の影響が大きい。詳細な原 価計算に基づくデータが救急医療といえども様々な分析 を可能にしている。たた，どれほど優れたシステムから 導かれる豊富な経営指標であっても, 実際の経営に必要 なのは解釈と応用であって, 救急医療に導入可能な戦略 に結びつかなければ意味がない。今後の活用に大いに期 待が持てる発表である。 


\section{SW4 総括 -1}

聖マリアンナ医科大学救急医学 明石 勝也

国民医療費の削減が政策目標として掲げられている現 在, 医療の各分野で経営効率を高めることが求められて いる。病院においては診療部門の採算性さえも問われる ようになってきている。救急医療は政策医療の一環とし て不採算医療の一つと考えられてきたが，採算性の向上 を目指した自助努力が必要な時代を迎えたといえよう。

そもそも救急医療は 24 時間営業であるため, 莫大な人 件費を要し, 尚且つ迅速かつ安全な診療のために大型医 療機器などの高額な設備投資が必要で, 救急部門単独で の収支を見ると赤字運営に陥りやすい。しかしながら救 急部門を抱える母体病院の多くを全体として捉えると， 救急経由で入院する患者数は病院の医療収入に大きく貢 献するものであり, 救急部門での患者受け入れがスムー スであることが周辺地域に与える信頼感, 安心感は計り 知れず, 病院全体の患者数増加に大きく寄与しているに 違いない。

経済用語に例えると, 病院全体を視野に入れたマク口 的分析と, 救急部門だけを捉えたミクロ的分析に分けて 考えることができるが, 今回のワークショップではミク 口的分析の発表が中心であった。重症患者の入院診療に 主力を置く運営方式は単独で採算性の維持が可能である が, 重症度を問わない救急外来診療中心の施設では患者 数とここから発生する入院患者数が採算性を左右するよ うである。部門の採算性向上のための管理会計，すなわ ち原価計算の仕組みの導入も重要な今後の課題であるが, やはり病院全体としてのマクロ的救急医療採算分析の意 識が病院管理職に必要である。

病院全体でマク口的経済効果から救急部門を支援する, という考え方が地域の救急医療環境も改善するというこ とにつながることになり「皆で救急医療を一生懸命頑張 れば, 病院は繁栄する」という, 実はとても単純な結論 のようにも思えてならない。

\section{SW 4 総括-2}

宮崎大学医学部病態解析医学講座救急 - 災害医学分野 寺井 親則
はじめに

救急医療は安心かつ健康的な生活を営むために欠くこ とのできない社会基盤の一つである。したがって，警察 や消防と同じょうに損益などの商業主義的概念になじま ないし，仮に経営上不採算であったとしてもそれは財政 資金で補えばよいとする考え方がある。しかしながら， この考え方は財政赤字の削減が喫緊の課題となっている わが国の現状からみて説得力にそしい。今後も続くであ ろう緊縮財政と医療機関の厳しい経営環境を考えれば, 救急医療といえども採算を考え, 経営の効率化を推進し なければ優れた救急医療サービスを将来にわたって提供 し続けることは難しくなる，と考える方がむしろ自然で あろう。こうした観点から第33回日本救急医学会 (東京, 2005 年) のシリーズ・ワークショップ「救急医療を考え る一明るい未来を拓くために今一」のサブテーマの一つ に「救急医療の採算性」が取り上げられた。本稿では，こ こでの口演内容と討議を踏まえて, 救急医療の採算性と 診療報酬に関連した課題を, 救命救急センターを中心に 考察する。

\section{1. 救急医療の採算性}

救急医療，なかでもその主体をなす救急部門はその設置 目的や所在する医療圈の医療環境などから様々な形態を とっており，一律にその採算性を論じることはできない。 そこで, 本ワークショップでは, まず救急部門を, (1)救急 外来で初期診療のみを担当するもの (ER型救急), (2)母体 病院に併設された救命救急センターで外来診療を主体とす るもの (ER主体の併設型救命救急センター), (3)母体病院 に併設された救命救急センターで高次の救急診療を主体と するもの（高次救急が主体の併設型救命救急センター）, (4)救急部門それ自体が一つの医療機関になっているもの (独立型救命救急センター)，の4つのカテゴリーに大別 し，それぞれの収益·経費構造を発表して頂いた。本稿で は, これとは別に, 救急医療の波及的収益についても検討

し, 救急医療そのものの採算性を考えることにする。

\section{1）救急部門の収益・経費構造}

(1) ER 型救急

ER型救急は独歩で来院する救急患者も積極的に受け入 


\section{SW4 救急医療の採算性}

れているので，一般に外来患者は多い。しかしながら，時 間外受診非救急患者や初期救急患者（一次の救急患者） の外来単価は時間外加算等を考慮しても総じて低く, こ れらの患者のみで医療関係者の24時間体制の配置に見合 うだけの収益を得るのは難しい。これに対し，二～三次 の救急患者は相対的に外来単価が高く, また母体病院の 入院患者にもなる。したがって, 二〜三次の救急患者を 増やせば, ERの増収のみならず母体病院の収益向上にも 貢献することができる。ER型救急における経費の大部分 は給与費である。その対策として研修医や若手の医師に 救急外来を委ねている施設もある1)が，そうした施設で は屋根瓦方式などで研修医や若手の医師の指導・監督体 制を強化し，安全で質の高い医療を担保する必要がある。 (2) ER 主体の併設型救命救急センター

ER が主体であることから患者数を確保しやすい。ま た, 救命救急センターであることから重症救急患者の診 療を行う機会も多い。救急医が入院後も継続して診療を 行う患者の中には救命救急入院料の加算対象患者も含ま れているので ER 型救急に比べかなりの増収が期待され る。経費面では材料費（薬品費, 診療材料費など）の適 正化が課題になる。この対策として, 後述の高次救急が 主体の併設型救命救急センターも同様であるが, 母体病 院を含めた物流の効率化策, たとえば在庫管理システム やSPD（Supply Processing and Distribution）などの導入, が推進されている。過剩在庫 - 使用期限切れ - 不動在庫 などの解消が期待されるので, こうした中央管理システ ムをできるだけ早く導入すべきである。ER主体の併設型 救命救急センターは収容する患者数, 患者の収益貢献 度 ${ }^{2)}$ 等にもよるが, 採算性は十分に確保される3) と考え られる。

(3)高次救急が主体の併設型救命救急センター

一般に高次の救急患者の外来単価は高い。もち万ん救 命救急入院料の加算対象患者も多く, 患者 1 人 1 日あた りの平均入院単価は一般の入院患者のそれより高額にな る。実際, 大阪大学の試算4)によれば, 付設の高度救命 救急センターの入院患者と附属病院の入院患者の平均入 院単価を比較すると約 3 倍の格差があったという。した がって, 高次救急に見合う入院患者を増やせば, 高収益 が期待される。経費面では給与費と材料費の適正化が課 題になる。高次救急が主体の併設型救命救急センターは ERが主体のそれと比較して, 必要とする救急医が多くな りがちであり，そのぶん給与費も高くなる傾向がある。 しかしながら，上述したように高収益が期待されること に加えて, 医師・看護師以外の職員のほとんどが母体病 院と職務を兼ねている。また, 大掛かりな診療器機等も
母体病院と共用である。したがって, コストの適正化等 にもよるが, 診療利益は十分に期待される5)。

(4)独立型救命救急センター

収益面での特徵は高次救急が主体の併設型救命救急七 ンターと概ね同じであるが, 経費面で決定的に違う点が ある。それは給与費が圧倒的に高く4), それが経費の極端 な過剩を招いている点である。独立型救命救急センター は瀕死の重症患者を選択的に受け入れる施設であること から, 病床数は少ないものの, 専門分野の異なる医師を 多数抱えている。また, 併設型の救命救急センターと 違って, 部署ごとに専任の職員を配置せざるをえない。 こうした施設特有の事情のため, 材料費の削減等の不断 の経営努力を行っても財政支援なしでは赤字の回避が困 難である ${ }^{6)}$ 。それ故, 財政措置の根拠となる経営状況なら びに医療内容についての情報提供を積極的に行い, 今ま で以上に説明責任を果たしていく必要がある。またこ うした当面の取り組みとは別に，財政支援に依存せず経 営基盤の安定化を図っていくためには, 将来いかなる運 営形態が望ましいのかについて, 抜本的な検討がなされ るべきである。

以上のカテゴリー別検討から, 独立型救命救急セン ターを除けば, 救急部門が赤字体質であるというわけで はなく, 採算のとれる経営基盤が今でも整っていると考 えられる。但し，これを実際の採算性向上につなげてい くためには, 上述したように, 救急部門の医療資源の価 值を最大化するように努めるとともに, 損益計算（原価 計算）に基づく経営指標等を参考にして自施設の効率的 運営を図っていく必要がある7,8)。

\section{2. 母体病院への波及的収益}

重症救急患者の多くは救急部門のみで治療が完結せず, 急性期を脱した後は母体病院で引き続き治療を行ってい く場合が多い。また, 初期救急患者も 2 回目以降は母体 病院の該当診療科の外来を受診する場合が多い。いずれ にしても, これらの患者は救急医療によって得られた新 規の患者であり, 救急医療の波及的効果と見なすことが できる。高岡ら ${ }^{1)}$ は母体病院の入院患者を調査し, その 実に $55 \%$ \% ER 経由であったと報告している。また, 中 尾ら 9) はER 経由の入院患者の収益を算出し, それが総 入院収益の $42.8 \%$ を占めていたと報告している。つまり, 救急医療の波及的収益は予想をはるかに越えた額になり うるので, これを無視して救急医療の真の採算性は論じ 得ないと言える。更に言えば, 救急医療への積極的な取 り組みは, 地域住民に安心感をもたらし, それが母体病 院への信頼感につながり, 結果として患者が増えていく, 
シリーズ・ワークショップ

という良循環を形成する効果もあることも強調すべきで ある。

\section{3. 診療報酬に関連した課題}

\section{1）救急部門のカルテ}

救急部門は元来が中央診療部門であり, 標榜診療科のよ うに診療報酬を独自に請求することができない。そのため 救急部門のカルテすら存在しない医療機関もある1,10)。し かしながら, カルテがなければ救急部門の診療実績や, 救 急部門が病院経営にどれだけ貢献しているのかを明確にす ることができない。もちろん, 増員要求や新規医療機器の 購入等を要求する場合の採否判断もできない。カルテは院 内, 特に事務部門, の理解さえ得られれば容易に作成する ことができるので，できるだけ早く整備すべきである。

\section{2）救命救急入院料の加算方式}

救命救急センターには救命救急入院料が設定されてお り, それが救命救急センターの安定経営に役立っている のは疑いのない事実である。しかしながら，この加算の 仕組みは実際に投入された医療経費を正しく反映してい ない。たとえば, 救命救急入院料は, 7 日以内が 1 日に つき 90,000 円·104,000円/日（それぞれ救命救急入院料 1, 2。以下, 同じ), 8-14 日が74,900円・88,900円/日と 定められている。一方, 臨床の現場では救急患者の病態 を解明し，治療方針を決定するため検査等を入院当初に 集中的に行う場合が多い。したがって, 現行の救命救急 入院料の加算方式では, 入院当初の数日はむしろ救命救 急センターの持ち出しとなり, その持ち出し分をその後 の入院期間中に回収しているのが実情である。つまり, より多くの重症救急患者を収容するために在室期間の短 縮に努めている救命救急センターほど収益が悪化する診 療報酬体系になっている。こうした矛盾を解決するには, 救命救急入院料の傾斜分配を投入経費の実態に合うよう に改める必要がある4)。

\section{3）救命救急センターの初診料}

救命救急センター初診料（救命救急入院料の初日分算 定）についても実態に即して改めるべきである。救命救 急入院料は加算対象が限られている上に救命救急セン ターに入院した患者のみに算定できる仕組みになってい る。一方, 救急隊が搬送してきた患者の中には, 外来で 死亡する患者や結果として救命救急入院料の加算対象で なかった患者も含まれている。救命救急入院料を算定で きる，できないに係らず，患者が搬入されると多くの医 療資源を同じように投入せざるを得ない。その後に救命 救急入院料を算定できないことが分かると, 救命救急セ ンターの明らかな持ち出しとなる。こうしたリスクを回
避するため救命救急センターが救命救急入院料を確実に 算定できる患者のみを収容するようになれば，地域の救 急医療システムは確実に崩壊するであろう。それゆえ， この問題についても実態に即して対応すべきであり, 救 急隊や他院からの紹介患者については, 死亡症例を含め て, 救命救急センター初診料として救命救急入院料の初 日分を算定できるように改めるべきである。

\section{4）救命救急センターと院内 ICU}

救命救急センターは院外で発生した重症救急患者を収 容する施設であり，院内で発生した重症患者を収容して も救命救急入院料は算定できない。院内で発生した重症 患者は院内ICUで診療することになっており，その場合 は特定集中治療室管理料を算定できる。しかしながら， 救命救急センターや院内ICUを運営するためには多数の 医療関係者を必要とする。それ故, これらの施設を別々 に運営することができる病院は限られてくる。こうした 事情から, 救命救急センターの病床の一部を院内ICUと して流用しても事実上黙認されてきた。重症救急患者の 発生が少ない地方都市の救命救急センターでは人的・物 的資源の効率的活用という観点から，今後もこうした流 用を続けざるをえないであろう。三位一体改革に伴う救 命救急センター運営費補助金の廃止にあたり,こうした 規制的な措置は緩和すべきである。これは救命救急セン ターの運営赤字を防ぐためにも必要である。

\section{おわりに}

病院経営が厳しさを増す中で, 救急部門は赤字を垂れ 流していると事務方や他の診療科の医師達からみられる ことほど救急医のプライドが傷つけられることはない。 こうした風評は救急医の病院内での発言力を殺ぐことに つながり, 意欲のある救急医ほど救急医療の現場から離 脱していくという深刻な事態を招いている。では，本当 に救急医療は赤字体質なのであろうか，シリーズワーク ショップ「救急医療を考える一明るい未来を拓くために 今一」の「救急医療の採算性」でなされた集中討議で，お ぼろげながらその解答が浮かび上がってきたのではなか ろうか。また，それと同時に改善すべき点，新たに検討 すべき課題等も提起された。もちろん,このワーク ショップのみで「救急医療の採算性」が十分に議論され たとは思っていないし，ここで取り上げることができな かった課題や本稿の私見に対する反対意見も多々あるで あろう。今回のワークショップを契機として, 本学会や 関連学会で再度このような企画が立てられ, 更なる議論 の進展があることを期待したい。 


\section{SW4 救急医療の採算性}

\section{文献}

1）高岡諒，林峰栄，加藤千紘，松本廣嗣：典型的 ER の採 算性.

2）遠山峰輝, 堤達朗, 田中伸明: 病院経営を科学する!一 「問題解決型思考」が切り開く病院経営の新手法. 東京, 日本医療企画，2003，p18-30.

3）川上正人, 野口和男, 田原憲一, 他: 自治体病院併設型 救命救急センターにおける救急専従医の採算性.

4）杉本壽: 救急医の養成と確保法についての研究. 厚生労 働省医療技術評価総合研究事業 平成 17 年度総括・分 担研究報告書, 2006 .

5）小関一英:自己完結型運営による救命救急センターの収 益と採算性.

6）森田大:独立型救命救急センターの運営実績からみた経 営分析.

7）池田吉成：診療科別部門別損益計算（原価計算）の活用 方法. 病院 $2005 ; 64: 57-60$.

8）岡本健，松島俊介，寺井親則: 国立大学病院管理会計シ ステムを用いた救急医療部門の収支分析の試み.

9）中尾博志, 山本和子, 勝井真由美, 他: 公立甲賀病院に おける救急患者の現状とその経済的波及効果について. 公立甲賀病院紀要 $2000 ; 3: 45-9$.

10）木村真一：2 次救急は本当に赤字なのか ? - 救急の収益 評価の指標一。

※1），3，5，6，8，10）は今回の口演プロシーディン グです。

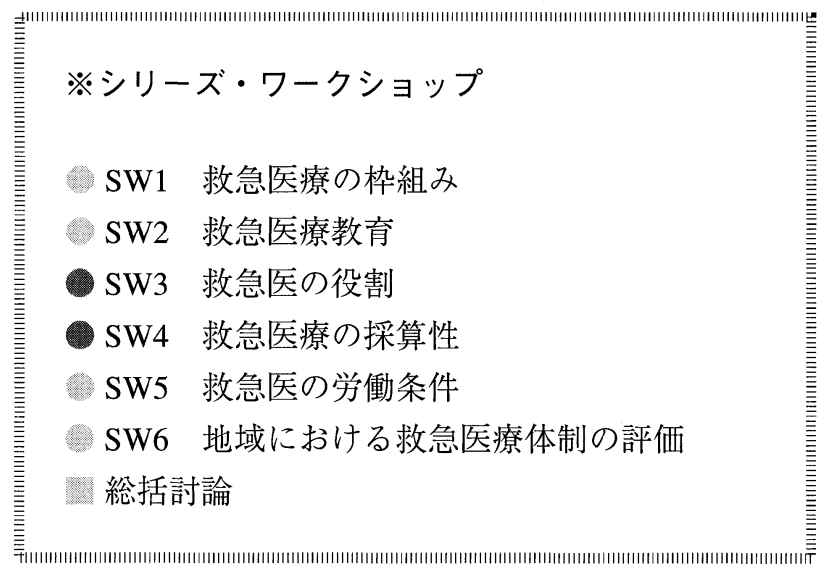

